TATIANA MELLO GUAZZELLI

\title{
CÉDULA DE CRÉDITO BANCÁRIO: ASPECTOS JURÍDICOS DE SUA NEGOCIAÇÃO E PROTEÇÃO DOS INVESTIDORES
}

Dissertação apresentada ao Departamento de Direito Comercial da Faculdade de Direito da Universidade de São Paulo, como exigência parcial para a obtenção do título de Mestre em Direito, sob orientação da Profa. Dra. Priscila Maria Pereira Corrêa da Fonseca.

FACULDADE DE DIREITO DA UNIVERSIDADE DE SÃO PAULO São Paulo 


\section{AGRADECIMENTOS}

Meus sinceros agradecimentos a todos os que tornaram possível a elaboração deste trabalho.

Aos meus pais, Roberto e Isabel, e à minha irmã Renata, pelo carinho e motivação, que foram fundamentais no desenvolvimento do presente trabalho.

Aos meus avós, Ubirajara (in memoriam) $e$ Rosa Emília, pelo amor e presença constante, que tanto contribuíram para o meu crescimento pessoal $e$ profissional.

Ao Eduardo, pelo apoio incondicional e pela compreensão nos momentos de ausência em virtude da dedicação a este trabalho.

À professora Priscila Maria Pereira Corrêa da Fonseca, pela confiança, dedicação e orientação.

Aos professores Paulo Fernando Campos Salles de Toledo e Antonio Martin, pelos comentários e sugestões apresentados a este trabalho durante o exame de qualificação, que muito contribuíram para a sua elaboração.

Ao Pinheiro Neto Advogados, em especial ao Bruno Balduccini e José Luiz Homem de Mello, pelo constante incentivo para o aprimoramento $e$ crescimento profissional. 
O problema fundamental em relação aos direitos do homem, hoje, não é tanto o de justificá-los, mas o de protegê-los.

Norberto Bobbio 


\section{RESUMO}

Muitas controvérsias cercam, atualmente, a negociação da Cédula de Crédito Bancário (CCB), dividindo a doutrina e atraindo a atenção do mercado financeiro e de capitais. A discussão central gira em torno da natureza jurídica da CCB, mais especificamente de seu enquadramento no conceito de valor mobiliário, do qual decorreria a competência da Comissão de Valores Mobiliários para regulamentar e supervisionar as ofertas públicas de CCBs. A análise da natureza jurídica da CCB torna-se, assim, imperativa para a delimitação do campo de atuação da Comissão de Valores Mobiliários. Para fins dessa análise, examina-se neste trabalho, inicialmente, o conceito e características dos títulos de crédito e valores mobiliários. Analisa-se, ainda, o conceito de CCB, sua origem, finalidade no âmbito do mercado financeiro, elementos característicos e modelos de negociação. Este trabalho também tem por escopo a investigação dos riscos associados à CCB e o exame da necessidade e das formas de se assegurar a proteção dos investidores. Diante dos elementos característicos da CCB e do conceito de valor mobiliário adotado pelo direito brasileiro, este trabalho conclui sobre a não caracterização da CCB como valor mobiliário. Este trabalho propõe-se, ainda, a concluir sobre os mecanismos adequados de proteção daqueles que investem em CCBs, em vista dos riscos inerentes a esse título de crédito.

PALAVRAS-CHAVE: Cédula de Crédito Bancário - Título de Crédito - Valor Mobiliário - Comissão de Valores Mobiliários - Investidor. 


\begin{abstract}
Several controversies currently surround the trading of Bank Credit Note (Cédula de Crédito Bancário - CCB), dividing the doctrine and attracting the attention of financial and capital market. The main discussion is around the legal nature of CCB, more precisely around the characterization of $\mathrm{CCB}$ as security, from which would arise the competence of the Brazilian Securities Commission to regulate and supervise the public offering of CCBs. The exam of the legal nature of the CCB becomes, therefore, imperative for delimitation of the actuation field of Brazilian Securities Commission. For purpose of this analysis, it is initially examined in this work the concept and characteristics of the titles of credit and securities. It is also examined the concept of CCB, its origin, purposes within the financial market, characteristics elements, and trading models. This work has also as scope the investigation of the risks associated to $\mathrm{CCB}$ and the exam of the need and forms to assure the investors' protection. Considering the characteristics elements of $\mathrm{CCB}$ and the concept of security adopted by Brazilian law, this work concludes that the CCB does not constitute a security. This work also concludes on the proper mechanisms for the protection of those who invest in CCBs, given the risks inherent to such title of credit.
\end{abstract}

KEYWORDS: Bank Credit Note - Title of Credit - Security - Securities Commission Investor. 
PRIMEIRA PARTE. TÍtUlo DE CRÉdito E VAlOR MObILIÁRIO: CONCEITO E CONTORNOS

1. CONSIDERAÇÕES INICIAIS SOBRE O MERCADO FINANCEIRO 13

2. TÍTULOS DE CRÉDITO .17

2.1. Conceito 17

2.2. Elementos característicos. 18

3. VALORES MOBILIÁRIOS 21

3.1. O direito norte-americano e o conceito de securities 21

3.2. O direito europeu e a conceituação de valor mobiliário .26

3.3. O conceito de valor mobiliário no direito comunitário europeu. 29

3.4. O conceito de valor mobiliário no direito brasileiro 31

4. A RELAÇÃO ENTRE TÍTULOS DE CRÉDITO E VALORES MOBILIÁRIOS ....38

5. NEGOCIAÇÃO DE VALORES MOBILIÁRIOS 41

5.1. Oferta pública de valores mobiliários 41

5.2. Oferta pública com esforços restritos 50

5.3. Oferta privada 52

6. PROTEÇÃO DOS INVESTIDORES NO MERCADO DE CAPITAIS .55

SEGUNDA PARTE. CÉDULA DE CRÉDITO BANCÁRIO 58

1. INCURSÃO HISTÓRICA SOBRE A CRIAÇÃO DA CCB . 59

2. CONCEITO E ELEMENTOS CARACTERÍSTICOS 63

2.1. Conceito 63

2.2. Requisitos 65 
2.3. Garantias que podem ser atreladas à CCB. 65

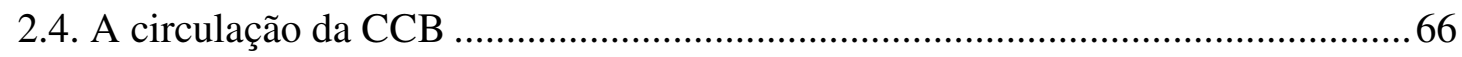

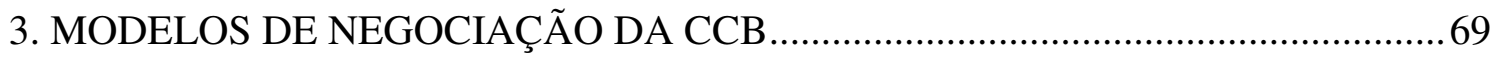

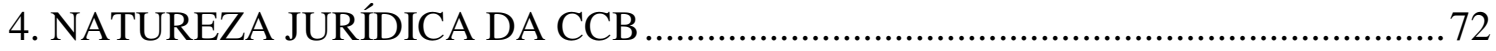

5. PROTEÇÃO DOS INVESTIDORES DE CCB ...................................................... 78

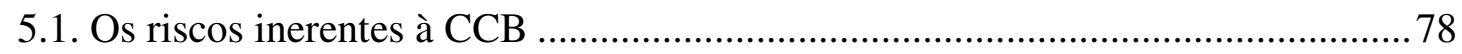

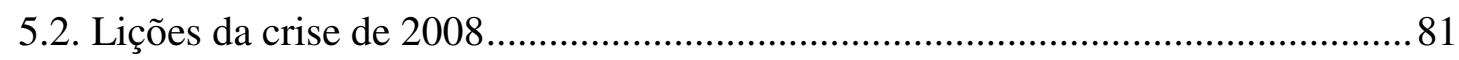

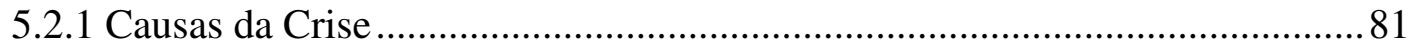

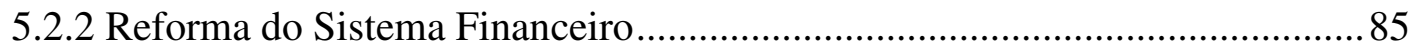

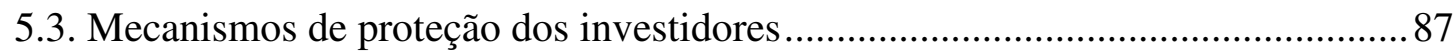

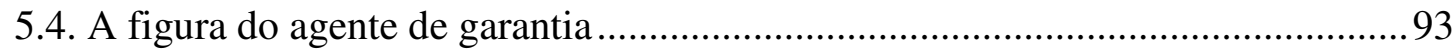

5.4.1 O agente fiduciário no Brasil e em outras jurisdições ...................................94

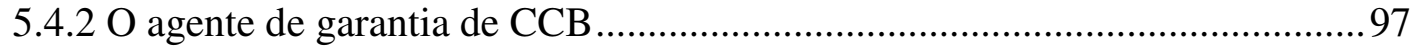

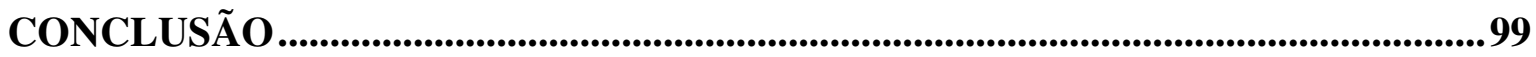

REFERÊNCIAS BIBLIOGRÁFICAS................................................................................104 


\section{INTRODUÇÃO}

A Cédula de Crédito Bancário (CCB) foi criada, em 1999, pela Medida Provisória $\mathrm{n}^{\mathrm{o}}$ 1.925, como uma resposta do Governo Federal às demandas das instituições financeiras brasileiras por mecanismos mais ágeis e eficientes de cobrança de crédito, que propiciassem uma maior segurança e, ao mesmo tempo, a flexibilidade necessária para operações de crédito bancário. À época da criação da CCB, o Sistema Financeiro Nacional carecia de um título adequado para instrumentalizar e garantir as operações de crédito.

O Poder Executivo decidiu então criar a CCB, que consiste em um título de crédito emitido por pessoa física ou jurídica, em favor de instituição financeira ou entidade a esta equiparada, domiciliada no Brasil ou no exterior ${ }^{1}$, representando promessa de pagamento em dinheiro decorrente de operação de crédito, de qualquer modalidade.

A criação da CCB foi de grande relevância para o Sistema Financeiro Nacional, uma vez que introduziu um meio de redução dos custos envolvidos nas operações de concessão de crédito e, ao mesmo tempo, um instrumento flexível para a realização de tais operações. Em 2004, esse título de crédito foi definitivamente introduzido no ordenamento jurídico pátrio por meio da Lei ${ }^{\circ} 10.931$.

A CCB é um título executivo extrajudicial e, como tal, representa uma obrigação líquida e certa de pagar. Assim, a via judicial para a cobrança da obrigação consubstanciada na CCB é a execução por quantia certa, que reflete o método mais célere atualmente previsto na legislação processual brasileira. A CCB contrapõe-se, portanto, a outros instrumentos de crédito existentes, cuja força executiva vem sendo questionada, como é o caso do contrato de abertura de crédito ${ }^{2}$ e da nota promissória ${ }^{3}$.

\footnotetext{
1 Quando em favor de instituição financeira domiciliada no exterior, a CCB pode ser emitida em moeda estrangeira.

2 É entendimento assente no Superior Tribunal de Justiça que o contrato de abertura de crédito, ainda que acompanhado de extrato da conta-corrente, não constitui título executivo extrajudicial, porquanto carece da liquidez característica dos títulos de crédito (Súmula 233 do STJ).

3 É igualmente pacífico o entendimento do Superior Tribunal de Justiça no sentido de que a nota promissória vinculada a contrato de abertura de crédito não goza de autonomia em razão da iliquidez do título que a originou (Súmula 258 do STJ). Assim, segundo o entendimento desse Tribunal, havendo tal vinculação, a instituição financeira não poderia usar o rito executivo para cobrança judicial de nota promissória.
} 
É cada vez mais frequente a utilização de CCBs no mercado financeiro para formalizar e representar operações de crédito originadas por instituições financeiras. A utilização desse título pode ser verificada tanto em operações usuais de financiamento, em substituição aos tradicionais contratos de crédito, como em operações de crédito mais complexas.

Não obstante a grande relevância da $\mathrm{CCB}$, esse título é cercado por diversas polêmicas. Inicialmente, foi questionada a constitucionalidade do veículo legislativo empregado em sua criação. À época, grande parte da doutrina entendeu que uma medida provisória não seria a norma adequada para a criação da $\mathrm{CCB}$, uma vez que não estavam presentes os requisitos constitucionais de relevância e urgência. Com a edição da Lei $n^{\circ}$ 10.931/04, essa questão foi superada.

A CCB teve também sua executividade questionada perante o Poder Judiciário logo após o advento da Medida Provisória $\mathrm{n}^{\circ}$ 1.925/99. Num primeiro momento, esse questionamento dividiu a jurisprudência. Apesar de a referida medida provisória ter previsto expressamente que a CCB constitui título executivo extrajudicial, havia decisões em sentido contrário. Mesmo ainda existindo precedentes contrários à eficácia executiva da $\mathrm{CCB}$, hoje predomina perante os tribunais o entendimento de que se trata de título executivo extrajudicial. A força executiva da CCB foi, inclusive, ratificada pela Quarta Turma do Superior Tribunal de Justiça em recente decisão a respeito do assunto.

Atualmente, as principais polêmicas, que vêm dividindo a doutrina e sendo objeto de atenção e preocupação do mercado financeiro e de capitais, estão relacionadas com a negociação de CCBs no mercado de capitais doméstico, sobretudo com o enquadramento da CCB no conceito de valor mobiliário. Questiona-se se a CCB pode ser entendida como valor mobiliário - no caso desse título ser negociado no âmbito de uma oferta pública -, o que acarretaria a competência da Comissão de Valores Mobiliários (CVM) para regulamentar e fiscalizar essas ofertas. Discute-se, ainda, se a realização de tais ofertas coaduna-se com a natureza e finalidade das CCBs ou se importa em um desvirtuamento desses títulos.

Os membros do Colegiado da CVM proferiram, no final de janeiro de 2008, o entendimento de que as $\mathrm{CCBs}$ devem ser consideradas valores mobiliários caso a 
instituição financeira em favor da qual elas forem emitidas: (i) realize uma oferta pública de CCBs; e (ii) exclua sua responsabilidade nos títulos.

O entendimento da CVM dividiu a doutrina pátria. Enquanto há doutrinadores que compartilham desse entendimento, muitos consideram que as características da CCB não se coadunam, sob nenhuma circunstância, com o conceito de valor mobiliário e, portanto, não tem a CVM legitimidade para regulamentar e fiscalizar a circulação desse título.

Outra questão envolvendo a negociação de CCB que vem sendo objeto de atenção do mercado e dos órgãos reguladores diz respeito à transparência e avaliação dos riscos inerentes a esses títulos, principalmente quando negociados no mercado.

Diante da agilidade de circulação de crédito propiciada pela CCB, são cada vez mais frequentes as negociações desse título, sobretudo no âmbito privado. Conforme previsto na Lei $\mathrm{n}^{\circ} 10.931 / 04$, a CCB é transferível mediante endosso em preto, devendo o endossatário ser identificado. Uma vez verificado o endosso, o endossatário, mesmo não sendo instituição financeira ou entidade a ela equiparada, passará então a figurar como credor na relação de crédito representada pela $\mathrm{CCB}$, podendo exercer todos os direitos e prerrogativas inerentes a tal condição, conforme descritos no título.

Um número significativo de instituições financeiras utiliza a CCB como instrumento de concessão de crédito, muitas das quais negociam esse título logo após sua emissão. É, portanto, expressivo o número de CCBs atualmente negociadas no mercado, sendo crescente a preocupação com os riscos incorridos por seus adquirentes.

Ao contrário de outros títulos, como a debênture, que apenas pode ser emitida por sociedade anônima, a CCB pode ser emitida por quaisquer pessoas físicas ou jurídicas. Em adição, não há critérios bem definidos na legislação e regulamentação com relação ao processo de análise do risco de crédito quando da emissão da CCB. Assim, o trabalho de avaliação do risco envolvido em uma CCB é extremamente complexo. Essa questão lembra a recente crise dos subprime nos Estados Unidos, que ocorreu na esteira da concessão de créditos sem uma análise criteriosa e posteriores negociações de tais créditos envolvendo sofisticados instrumentos financeiros. Entre outras lições, a crise mostrou as consequências nefastas que uma administração inadequada de ativos que lastreiam títulos 
emitidos no mercado, associada à ausência de uma minuciosa avaliação dos riscos envolvidos, pode provocar.

Diante desse cenário, os órgãos reguladores e entidades representativas do mercado financeiro e de capitais vêm destacando a necessidade de serem adotados mecanismos de diligência e monitoramento, de modo a mitigar os riscos envolvidos na negociação de CCBs, seja de forma privada ou pública.

A utilização da CCB no mercado financeiro e de capitais brasileiro e sua natureza jurídica serão objeto deste estudo. Que a CCB é um título de crédito não resta dúvida. É a possibilidade de seu emprego como valor mobiliário e, por conseguinte, a delimitação do campo de atuação da CVM que serão analisadas neste trabalho. Na primeira parte deste trabalho, após uma breve introdução sobre o mercado financeiro e exposição sobre títulos de crédito, serão estudados o conceito de valor mobiliário, a evolução legislativa em torno desse conceito, sua relação com os títulos de crédito, as formas de negociação dos valores mobiliários e proteção dos investidores no mercado de capitais. Na segunda parte do presente trabalho, serão examinados o conceito e elementos característicos da CCB, para então adentrar-se na análise de sua natureza jurídica.

Será examinado, ainda, como vêm sendo realizadas as negociações de CCB, bem como os riscos inerentes a esse título, a necessidade de proteger os investidores diante de seus elementos característicos, e as formas de se alcançar tal proteção.

O tema deste estudo mostra-se atual e relevante, não só do ponto de vista acadêmico, quanto prático, especialmente diante do expressivo crescimento do volume de negociação de CCB no mercado brasileiro. 
PRIMEIRA PARTE

TÍTULO DE CRÉDITO E VALOR MOBILIÁRIO:

CONCEITO E CONTORNOS 


\section{CONSIDERAÇÕES INICIAIS SOBRE O MERCADO FINANCEIRO}

O mercado financeiro é composto pelo conjunto de instituições e instrumentos destinados a viabilizar a transferência de recursos entre ofertantes e tomadores. Pode-se definir o mercado financeiro como o "local onde o dinheiro é gerido, intermediado, oferecido e procurado, por meio de canais que se entrelaçam na formação de sistemas" (RUDGE, CAVALCANTE, 1996, p. 36).

O mercado financeiro é tradicionalmente dividido em mercado financeiro propriamente dito (também chamado de mercado de crédito ou mercado bancário) e mercado de capitais (ou mercado de valores mobiliários). O primeiro, sob uma perspectiva funcional, é conceituado, nas palavras de Nelson Eizirik (1977, p. 28), como "um conjunto de mecanismos voltados para a transferência de recursos entre os agentes econômicos". Nesse mercado, a mobilização e a canalização dos excedentes são efetuadas por meio de um intermediário financeiro que se coloca entre o investidor e o beneficiário do investimento. Por outro lado, o mercado de capitais é caracterizado pela desintermediação financeira, e abrange o conjunto de operações com valores mobiliários, como ações, debêntures, notas promissórias, entre outros, as quais se realizam em bolsas e mercados organizados.

No mercado de crédito, o "intermediário financeiro", que geralmente são os bancos, centraliza a oferta e a procura de capitais e assume o risco da operação, cobrando, para tanto, uma taxa de juros. Já no mercado de capitais, os intermediários, como é o caso da Bolsa, não atuam como parte da operação, mas apenas como intervenientes obrigatórios. $\mathrm{O}$ mercado de capitais propicia aos empresários uma alternativa ao financiamento bancário, permitindo um equilíbrio entre fundos não exigíveis e endividamento.

Outra diferença entre esses dois mercados é o prazo das operações. No mercado de crédito as operações são, geralmente, de curto ou médio prazo. Já o mercado de capitais permite operações de longo prazo.

No entanto, guardadas as devidas diferenças, ambos os mercados possuem as mesmas finalidades. Otavio Yazbek (2009, p. 125), atualmente diretor da CVM, destaca 
que tanto no mercado financeiro quanto no mercado de capitais "estabelecem-se relações de conteúdo financeiro visando, fundamental, mas não exclusivamente, dois fins nem sempre concomitantes: a repartição de riscos e o financiamento das atividades econômicas".

A circulação da riqueza remonta à antiguidade. No entanto, um mercado financeiro, com traços semelhantes ao contemporâneo, começou a se desenvolver por volta do século XVII. Em 1609, foi criado o Banco de Amsterdã para regulamentar e limitar o abuso da moeda, o qual, conforme ressalta John Kenneth Galbraith (1997, p. 13), foi o primeiro banco público digno de nota. Por quase um século após sua constituição, esse banco permaneceu fiel aos seus objetivos iniciais, apenas mantinha os depósitos, nada era emprestado. Porém, entre o final do século XVII e o início do século XVIII, esse banco começou a utilizar os fundos nele depositados para realizar empréstimos à Companhia Holandesa das Índias Ocidentais. Tais operações foram bem sucedidas enquanto a Companhia era uma empresa rentável. Com o aumento dos déficits e dívidas da Companhia, no século XVIII, inclusive em razão da guerra com a Inglaterra, o Banco de Amsterdã começou a enfrentar dificuldades, as quais culminaram em seu fïm em 1819.

Ao longo dos séculos XVII e XVIII, foram criados outros bancos, que vieram a financiar governos e companhias para a exploração de riquezas. Esse foi o caso do francês Banque Royale, criado por John Law em 1716. À época, a situação financeira da França era caótica, marcada por insuficiência de moeda e excessivas desvalorizações. Law, que se dedicava aos estudos de economia e finanças e defendia que não poderia existir um país forte sem um banco forte, propôs a criação de um banco estatal centralizador. O Banque Royale conseguiu captar no século XVIII milhões de libras francesas com o objetivo de financiar a Companhia do Mississipi, também criada por John Law para explorar os depósitos de ouro que se acreditava haver no subsolo da Louisiana, então colônia francesa. No entanto, o verdadeiro destinatário dos investimentos acabou sendo o governo francês, e nenhum ouro de fato foi extraído, o que acabou levando ao fim o Banque Royale poucos anos após a sua criação, deixando na França "fortunas destruídas, preços em declínio, atividades empresariais em depressão e uma desconfiança duradoura de bancos e suas atividades" (GALBRAITH, 1997, p. 24). 
Uma carta enviada em 1816 por Thomas Jefferson, já então ex-presidente dos Estados Unidos, a John Taylor ilustra bem a desconfiança que existia na época. Nela, Thomas Jefferson afirmou que os estabelecimentos bancários deviam ser mais temidos do que exércitos permanentes.

O mercado de capitais também começou a se desenvolver no início da Idade Moderna. Já na Idade Média, cotas de participações em companhias eram comercializadas no meio das ruas, nas calçadas, semelhantemente a qualquer outro produto vendido na época. Mas foi apenas em 1602, em Amsterdã, que foi criada a primeira bolsa de valores, com a finalidade de negociar as ações da Companhia Holandesa das Índias Orientais. Já a Bolsa de Valores de Londres estabeleceu-se em 1690, e as Bolsas de Paris e de Nova York foram criadas e instaladas somente no século XVIII, em 1724 e 1792, respectivamente.

Foi ainda na Holanda que ocorreu a "crise das tulipas", considerada por muitos como a primeira bolha de mercado. As tulipas chegaram aos Países Baixos no século XVI, originárias da Turquia, e rapidamente se tornaram um artigo de luxo e símbolo de status. Em 1623, um único botão chegava a custar milhares de florins. Em meados de 1630, uma Semper Augustus, o bulbo mais famoso de tulipa, chegou a ser vendido pelo preço recorde de 6.000 florins. As negociações de tulipas, contudo, tinham uma restrição: os bulbos apenas floresciam na primareva, por uma ou duas semanas. Com o aumento do preço das tulipas, começou-se a criar uma forma de negociá-las mesmo fora da primavera: passou-se a negociar contratos futuros de tulipas nas bolsas de valores holandesas. Especuladores ganharam fortunas negociando esses contratos. Porém, após alguns anos, começaram a ser descobertas diversas fraudes - floristas estavam vendendo contratos falsos que não davam direito a bulbo algum, os preços despencaram, a desconfiança se espalhou, e rapidamente não havia mais compradores. Muitos investidores perderam tudo.

Os acontecimentos relatados acima, entre outros ocorridos nos séculos XVII e XVIII, ao mesmo tempo em que mostraram como o mercado financeiro e o mercado de capitais poderiam estimular a indústria e o comércio, revelaram a extensão dos prejuízos que poderiam causar. O economista americano John Kenneth Galbraith (1997, p. 25) resume, na seguinte frase, o dilema nascido com tais acontecimentos: "Aqui, em sua forma mais breve, estava enquadrado o problema que iria ocupar homens de gênio financeiro ou cupidez pelos dois séculos seguintes: como ter a maravilha sem o juízo final?”. 
Passou-se, assim, a buscar formas de se assegurar o bom funcionamento do mercado financeiro e de capitais. Com o passar do tempo, percebeu-se que o bom funcionamento desses mercados dependia de sua regulação e controle, e que, em razão das características peculiares desses mercados, era preciso uma legislação própria, dotada da flexibilidade necessária para acompanhar seus avanços.

No Brasil, tal flexibilidade foi alcançada através da criação de autarquias federais, vinculadas ao Ministério da Fazenda, para supervisionar o mercado financeiro e de capitais brasileiro, o Banco Central do Brasil e a Comissão de Valores Mobiliários, e da delegação, por meio de leis federais, de poderes a essas autarquias para emitir normas regulamentando tais mercados, sob a coordenação do Conselho Monetário Nacional. Esse sistema, ressalta Barreto Filho (1966, p. 173), "propiciou a indispensável flexibilidade à regulação dos preceitos legais, possibilitando sua adequação às contingências econômico-financeiras e ao comportamento dos negócios”. Em outros países, como os Estados Unidos, o poder normativo também foi descentralizado para se assegurar uma regulação mais eficaz do mercado financeiro e de capitais.

Embora se tenha percebido desde cedo que o bom funcionamento do mercado financeiro e de capitais dependia de sua regulação e controle e tenham sido criados processos legislativos próprios para permitir tal regulação, até os dias atuais ainda restam dúvidas sobre a forma de se regular e controlar tais mercados. Tanto é que, como se poderá ver adiante, vive-se atualmente um momento de grandes mudanças na regulação internacional do mercado financeiro e de capitais.

Essa questão está intimamente relacionada com o tema abordado no presente trabalho. Afinal, o que se pretende aqui analisar é como e através de qual arcabouço regulatório pode-se proteger de forma adequada os investidores de CCBs, diante dos riscos inerentes a esse instrumento típico do mercado financeiro.

Não obstante as incertezas existentes, é certo que a regulação do mercado financeiro e de capitais gira em torno dos instrumentos próprios desses mercados, especialmente os títulos de crédito, no caso do mercado bancário, e os valores mobiliários, no caso do mercado de capitais, os quais serão estudados a seguir. 


\section{TÍTULOS DE CRÉDITO}

\subsection{CONCEITO}

Os títulos de crédito possuem vital importância na sociedade contemporânea. Tullio Ascarelli (1999, p. 25), em seu estudo sobre a teoria dos títulos de crédito, destaca a grande contribuição desses títulos para a formação da economia moderna:

A vida econômica moderna seria incompreensível sem a densa rede de títulos de crédito; às invenções técnicas teriam faltado meios jurídicos para a sua adequada realização social; as relações comerciais tomariam necessariamente outro aspecto. Graças aos títulos de crédito pôde o mundo moderno mobilizar as próprias riquezas; graças a eles o direito consegue vencer o tempo e o espaço, transportando com a maior facilidade, representados nestes títulos, bem distantes e materializando, no presente, as próprias riquezas futuras.

Desde o surgimento da letra de câmbio na Idade Média, a doutrina e a jurisprudência apresentaram inúmeras definições para os títulos de crédito. Dentre as diversas definições formuladas, a definição dada por Cesare Vivante aos títulos de crédito é a que melhor identifica os atributos essenciais dos títulos de crédito. Vivante define título de crédito como "un documento necessário per esercitare il diritto letterale ed autonomo che vi è mencionato" ". Conforme observa Fran Martins (2008, p. 5), a definição vivanteana "é a mais completa, pois encerra, em poucas palavras, algumas das principais características desses instrumentos".

A definição formulada por Vivante foi, inclusive, adotada pelo Código Civil brasileiro de 2002, como mostra o texto do artigo 887: “O título de crédito, documento necessário ao exercício do direito literal e autônomo nele contido, somente produz efeito quando preencha os requisitos da lei”.

Outros grandes juristas, como Alberto Asquini, ao definirem título de crédito, destacam também os atributos essenciais desse documento identificados na definição vivanteana. Asquini (1966, p. 25) propôs a seguinte definição de título de crédito:

Titolo di credito è il documento di un diritto letterale destinato alla

\footnotetext{
${ }^{4}$ Tradução livre: um documento necessário para o exercício do direito literal e autônomo nele mencionado.
} 
circolazione, idoneo a conferire in modo autonomo la titolarità di tale diritto al proprietario del documento, e necessario e sufficiente per legittimare il possessore all' esercizio del diritto stesso. ${ }^{5}$

\title{
2.2. ELEMENTOS CARACTERÍSTICOS
}

Do conceito de título de crédito, depreendem-se seus requisitos, os quais Waldirio Bulgarelli (2000, p. 62) divide em requisitos ordinários e requisitos extraordinários. Para Bulgarelli, são requisitos ordinários, ou seja, essenciais, a cartularidade, a literalidade e a autonomia. Os requisitos extraordinários são a independência e a abstração.

A cartularidade consiste na materialização do direito no documento. Nos dizeres de Bulgarelli (2000, p. 63):

\begin{abstract}
A cartularidade, também chamada de incorporação, notadamente pelos autores espanhóis modernos, como Broseta Pont e Rodrigo Uria, e pelo nosso Eunápio Borges, e que consiste, em última análise, na materialização do direito, no documento. Daí se dizer que o direito se incorpora ao documento, expressão empregada até mesmo por Cesare Vivante.
\end{abstract}

O segundo requisito essencial do título de crédito é a literalidade uma vez que seu teor determina a existência, conteúdo, extensão e modalidade do direito nele mencionado (“quod non est in cambio non est in mundo"). Por essa razão, Ascarelli (1999, p. 64) pondera que "a literalidade age em duas direções, que podem dizer-se positiva e negativa, isto é, tanto contra, como a favor do subscritor, o que é natural tratando-se, em substância, da delimitação do direito mencionado no título de acordo com o teor do documento".

Por sua vez, a autonomia significa a ausência de vínculo entre o direito do adquirente do título de crédito e o direito de seu antecessor, a independência dos diversos e sucessivos portadores do título em relação a cada um dos outros. Fran Martins (2008, p. 7) ressalta que "nasce daí um princípio chamado inoponibilidade das exceções, segundo o qual não pode uma pessoa deixar de cumprir suas obrigações alegando (opondo exceções) suas relações com qualquer obrigado anterior do título”. O princípio da inoponibilidade encontra-se refletido no artigo 17 da Lei Uniforme de Genebra, ratificada pelo Decreto $\mathrm{n}^{\circ}$

\footnotetext{
${ }^{5}$ Tradução livre: Título de crédito é o documento de um direito literal destinado à circulação, idôneo para conferir de modo autônomo a titularidade de tal direito ao proprietário do documento, e necessário e suficiente para legitimar o possuidor ao exercício do próprio direito.
} 
57.663/1966, o qual estabelece:

As pessoas acionadas em virtude de uma letra não podem opor ao portador as exceções fundadas sobre as relações pessoais delas com o sacador ou com os portadores anteriores, a menos que o portador ao adquirir a letra tenha procedido conscientemente em detrimento do devedor.

Cabe notar que há uma segunda acepção em que é empregado o termo autonomia, a qual se refere à independência da obrigação cartular em relação à subjacente. Entretanto, conforme observa Paulo Toledo (1990, p. 136), esse significado deve ser evitado, pois confunde-se com o significado de abstração:

Ora, quando se diz que a obrigação cartular é autônoma em relação à subjacente, diz-se, ao mesmo tempo, que para analisar aquela pode-se fazer abstração desta. O significado, portanto, é exatamente o mesmo. Se assim é, melhor será dar-se o nome abstração a esse atributo dos títulos de crédito, a fim de evitar-se confusão com a segunda acepção em que é empregado o termo autonomia.

A abstração, por sua vez, portanto, está relacionada à causa de emissão do título de crédito. Diz-se que a abstração não é requisito essencial dos títulos de crédito, pois podem estes ser abstratos, isto é, não possuir uma relação com o negócio jurídico original, ou podem ser causais. Como ensina Fran Martins (2008, p. 11-12):

Podem os títulos de crédito se originar de um ato unilateral da vontade, sem causa aparente que force o seu nascimento (emito uma letra de câmbio em meu próprio favor e com meu aceite e a faço circular, transferindo-a a terceiro que, para recebê-la, me entrega a importância nela mencionada; não houve motivo outro que justificasse a criação do título senão minha própria vontade de criar um valor que transformo em dinheiro ao transferir o título a terceiro; com essa transferência me obrigo a reembolsar, em época futura, a pessoa que me apresentar a letra); podem, também, nascer em decorrência de um negócio real (compro determinados bens e como não posso pagar agora emito uma nota promissória; houve uma causa real que me levou a emitir o título, a compra dos bens cujo pagamento não posso fazer agora mas prometo fazer futuramente).

Ascarelli (1999, p. 167) assim explica a diferença entre títulos abstratos e causais:

(...) o subscritor do título causal, assinando o título, declara que o titular deste é credor em virtude de uma determinada relação fundamental (é, por exemplo, o sócio de certa sociedade; o destinatário de determinada carga) (...). Diferente é a situação nos títulos abstratos, a cujo respeito, 
pela sua própria abstração, não se poderia falar em correspondência do título com uma determinada relação fundamental.

Por fim, a independência significa que o título basta-se a si mesmo, sem a necessidade de outro documento para completá-lo. A independência também não é considerada um requisito essencial, pois o título de crédito pode ou não ser independente:

(...) enquanto, por exemplo, a letra de câmbio e a nota promissória são, em princípio, títulos independentes, pois não se remetem a qualquer documento para completá-los, já outros títulos dependem de documentos ou, se não dependem, estão estreitamente vinculados a outros documentos (BULGARELLI, 2000, p. 65).

Bulgarelli esclarece, ainda, as razões que podem levar um título de crédito a não ser independente:

A dependência do título pode, segundo nosso parecer, decorrer: a) da vontade das partes - quando referem no corpo do título a existência de outro documento, insertando-o na cártula por via da literalidade; b) de imposição legal, ou seja, quando é determinada por lei a ligação do título com outro documento, como ocorre, por exemplo, na cédula de crédito rural que a Lei vincula ao orçamento (Decreto-lei $\mathrm{n}^{\circ} 167$, de 14 de fevereiro de 1967); e c) resultar da própria substância e conformação do negócio e do título, como ocorre, por exemplo, com as ações de emissão das sociedades por ações, as quais, como títulos de participação, são complementadas necessariamente pelo estatuto da sociedade emissora. 


\section{VALORES MOBILIÁRIOS}

A análise jurídica dos valores mobiliários e o estabelecimento de sua conceituação têm se mostrado um grande desafio para a doutrina.

Conforme descreve Ary Oswaldo Mattos Filho (1985, p. 33), duas são as principais tendências quanto à caracterização legal de valores mobiliários: "A tradição europeia continental usualmente opta por definir o que é um valor mobiliário, já o direito norteamericano tentou listar, à exaustão, os títulos que preencham a condição de valor mobiliário". Será analisado o conceito de valor mobiliário nessas jurisdições para, então, passar-se ao exame do regramento nacional.

\subsection{O DIREITO NORTE-AMERICANO E O CONCEITO DE SECURITIES}

A crise enfrentada pela sociedade norte-americana entre as décadas de 20 e 30 expôs a fragilidade da estrutura do mercado de capitais norte-americano e deflagrou uma série de medidas por parte do governo visando a assegurar aos investidores do mercado de valores mobiliários uma maior proteção.

Antes da crise de 1929, as operações de compra e venda de valores mobiliários não eram objeto de legislação federal própria. Havia somente as blue sky laws que regulamentam no âmbito estadual a oferta e venda de valores mobiliários, visando a proteger os investidores contra fraudes. As disposições específicas dessas leis, em vigor até os dias de hoje, variam de estado para estado e cada um possui sua própria agência regulatória (Securities Commission) encarregada de fiscalizar a aplicação dessas leis.

Ademais, as bolsas de valores não estavam sujeitas a qualquer regulação governamental e durante muitos anos as tentativas de sujeitar as bolsas de valores à regulação federal ou estadual foram vigorosamente repelidas, argumentando-se que o sistema de autorregulação funcionava eficientemente. No entanto, a crise de 1929 mostrou que esse sistema não era tão eficaz como parecia. 
Nesse contexto, foram promulgadas duas leis federais disciplinando o mercado de capitais norte-americano. A primeira, o Securities Act, foi promulgada em 1933, com o objetivo principal de estabelecer regras e premissas para a negociação de valores mobiliários, tornando mandatório o fornecimento aos investidores de informações detalhadas a respeito de valores mobiliários objeto de oferta pública envolvendo mais de um estado. Logo em seguida, em 1934, foi editado o Securities Exchange Act que ampliou a doutrina do full disclosure (ampla e precisa informação aos investidores) também para títulos transacionados no mercado secundário e criou a comissão de valores norteamericana, a Securities Exchange Comission (SEC).

Foi a partir da promulgação dessas duas leis federais que a definição de valores mobiliários começou a ganhar importância no direito norte-americano.

O Securities Act de 1933 trouxe o conceito de securities, em sua "Section" 2, que assim dispõe:

The term "security" means any note, stock, treasury stock, security future, security-based swap, bond, debenture, evidence of indebtedness, certificate of interest or participation in any profit-sharing agreement, collateral-trust certificate, preorganization certificate or subscription, transferable share, investment contract, voting-trust certificate, certificate of deposit for a security, fractional undivided interest in oil, gas, or other mineral rights, any put, call, straddle, option, or privilege on any security, certificate of deposit, or group or index of securities (including any interest therein or based on the value thereof), or any put, call, straddle, option, or privilege entered into on a national securities exchange relating to foreign currency, or, in general, any interest or instrument commonly known as a "security", or any certificate of interest or participation in, temporary or interim certificate for, receipt for, guarantee of, or warrant or right to subscribe to or purchase, any of the foregoing. ${ }^{6}$

\footnotetext{
${ }^{6}$ Tradução livre: $\mathrm{O}$ termo security significa qualquer nota, ação, ação em tesouraria, títulos futuros, swap baseado em security, obrigação, debênture, comprovante de dívida, certificado de direito ou participação em qualquer contrato de divisão de lucro, certificado de depósito em garantia, boletim de subscrição, ação transferível, contrato de investimento, certificado de transferência de direito de voto, certificado de depósito de uma security, participação em royalty de petróleo, gás ou outro mineral, qualquer opção de venda, opção de compra, direito de preferência em relação a qualquer security, certificado de depósito de qualquer security ou índice de security (incluindo qualquer juros ou direitos sobre ele baseados em seu valor), ou qualquer opção de venda, opção de compra, direito de preferência negociado em bolsa de valores com relação à moeda estrangeira, ou, em geral, todo instrumento conhecido como security, ou ainda todo certificado de participação ou interesse, permanente ou temporário, recibo, garantia, direito de subscrição ou compra referentes aos títulos e valores acima mencionados.
} 
O dispositivo legal acima transcrito não traz propriamente uma definição de valor mobiliário ou security, mas uma relação, de forma exemplificativa - e não taxativa -, dos tipos de títulos que podem ser considerados uma security no direito norte-americano.

Em artigo sobre a conceituação dos valores mobiliários nos Estados Unidos da América e o conceito análogo no direito brasileiro, o professor Luiz Gastão Paes de Barros Leães (1974, p. 43) observa que a definição legal de security desobedece a uma das principais regras da boa definição, a de que o objeto definido deve necessariamente ficar excluído da definição:

Primeiro, não estabelece os "limites conceituais" do objeto definido: apenas enumera tipos da entidade designada pela definição. De resto, essa enumeração não é exaustiva: é puramente exemplificativa (numerus apertus). Ademais, com a expressão final: "or, in general, any interest or instrument commonly known as security", a definição inclui, no seu contexto, a própria coisa definida, agredindo uma das regras básicas da boa conceituação. Longe, pois, de fornecer a "essência" do conceito de security, o legislador se limita a enumerar, exemplificativamente, tipos que partilhariam de uma essência comum, de resto deixada indefinida. Por outro lado, a assertiva, acima comentada, de que seria security "any interest commonly known as security", é sobremodo vaga, indefinida, e até perigosa: "Comumente conhecida" por quem? Caberia essa identificação aos tribunais ou seria da competência das agências federais fiscalizadoras do mercado de valores?

De fato, a conceituação apresentada no Securities Act mostrava-se ao mesmo tempo incompleta, vaga e com um problema estrutural grave, uma vez que lhe faltavam elementos fundamentais a qualquer definição. A ideia de definir é a de estabelecer uma delimitação, uma fronteira, dentro da qual se inserem todos os elementos daquilo que se quer definir.

Diante das lacunas apresentadas pela legislação federal, os tribunais e a SEC passaram a ser frequentemente acionados para que se manifestassem com relação à definição de valor mobiliário, ou security. Em 1943, foi submetida à apreciação da Suprema Corte o primeiro caso envolvendo o conceito de valor mobiliário previsto no Securities Act, SEC v. C.M. Joiner Leasing Corporation ${ }^{7}$. Essa empresa, após adquirir, como arrendatária, três mil acres de terra no Estado do Texas, com o objetivo de explorar petróleo, mediante pesquisa e perfuração do solo, decidiu ceder partes do contrato de 
arrendamento. As cessões tinham por objetivo financiar o empreendimento. A Suprema Corte dos Estados Unidos entendeu que o empreendimento envolvia a oferta pública pela Joiner de securities, mais especificamente de investment contract. Tal entendimento foi fundamentado, principalmente, no fato de que referida empresa não oferecia meras cessões de arrendamento, mas sim instrumentos que possibilitavam aos investidores (cessionários) participar em eventuais lucros que viessem a decorrer da exploração dos poços de petróleo.

Em 1946, a Suprema Corte voltou a apreciar o conceito de investment contract, no emblemático caso SEC. v. W.J. Howey Company ${ }^{8}$. O caso Howey consistia na venda de pequenos lotes de terra pela Howey Company. Esses lotes de terra eram utilizados para o plantio de frutas cítricas. Além disso, outra companhia, a Howey-in-the-Hills Service Company, subsidiária da primeira, prestava os serviços de plantio e cultivo da terra, bem como os de comercialização das frutas ali produzidas. A conclusão da Suprema Corte foi a de que os pequenos lotes de terra vendidos pela Howey constituíam-se, na verdade, em "investimentos" feitos por centenas de pessoas, que, sem ter o conhecimento, experiência e equipamentos necessários ao cultivo das frutas cítricas, investiram "passivamente" em um negócio dirigido por terceiros, na expectativa de obter lucros, não se tratando, assim, de simples aquisições de glebas de terra, as quais, inclusive eram divididas em frações economicamente inviáveis quando consideradas isoladamente.

Não se atendo apenas à forma dos instrumentos envolvidos no caso, mas também analisando a realidade econômica da operação, a Suprema Corte norte-americana concluiu que os contratos de investimento (investment contracts) compreenderiam todo e qualquer instrumento que envolvesse " $(a)$ an investment of money $(b)$ in a common enterprise (c) with profits to come $(d)$ solely from the efforts of the promoter or a third party". 9

Dessa forma, o principal resultado do caso Howey foi a definição do contrato de investimento, ou investment contract, muito mais pela sua substância do que pela forma, identificando, desse modo, uma security com base na substância econômica subjacente. Nas palavras do professor Luiz Gastão Paes de Barros (1974, p. 48): “Assim, no caso em tela, foi identificada, num contrato de investimento, a realidade econômica da transação,

\footnotetext{
$8 \quad 328$ U.S. 293, 295-96 (1946).

9 Tradução livre: (a) um investimento de dinheiro, (b) em um empreendimento comum, (c) com lucros a advir, (d) unicamente dos esforços do empreendedor ou de um terceiro.
} 
que seria a substância comum às demais 'formas' de securities alinhadas na definição legal".

Após esse célebre caso, as Cortes norte-americanas passaram a procurar aplicar em muitos casos o chamado "Howey test" para determinar se o título, instrumento ou operação em exame, consistia ou não em uma security, ainda que nem sempre exigindo a presença de todos os requisitos da "Howey definition".

No caso United Housing Foundation, Inc. v. Forman ${ }^{10}$, por exemplo, julgado pela Suprema Corte dos Estados Unidos em 1975, foi aplicado por esse tribunal o "Howey test" para determinar se certas quotas (stock) enquadravam-se no conceito de security. As quotas em questão apenas outorgavam a seus titulares o direito de alugar um imóvel de uma cooperativa imobiliária sem fins lucrativos. Concluindo que a operação em questão não envolvia securities sujeitas à proteção da legislação federal, a Suprema Corte decidiu que a análise não poderia ser feita com base em uma interpretação meramente literal. Ao contrário, a Corte examinou a substância econômica da operação, citando o caso Howey, e concluiu que as quotas em questão não consistiam em securities por não possuírem as características básicas de uma quota (stock).

Já no caso Marine Bank v. Weaver ${ }^{11}$, julgado em 1982, a Suprema Corte norteamericana decidiu que determinados certificados de depósito bancário não poderiam ser classificados como valores mobiliários, por não terem sido objeto de uma oferta pública e já estarem sujeitos a um extenso rol de normas bancárias. Os certificados de depósito em questão foram emitidos pelo Marine Bank. Pesou, ainda, na decisão o fato de ser garantido ao adquirente de um certificado de depósito bancário o pagamento integral do respectivo valor, ao contrário, por exemplo, de um título de dívida cujo adquirente assume o risco de insolvência do devedor. Entendeu, assim, a Suprema Corte que as partes já estavam devidamente protegidas, não havendo necessidade de se aplicar a regulação ou a fiscalização pertinente aos valores mobiliários.

Vê-se, assim, que, diante da ausência de uma efetiva definição legal de security, os tribunais norte-americanos foram convocados em diversos momentos a se manifestarem 
acerca de tal conceito. Nesse sentido, construiu-se uma interpretação jurisprudencial em torno do conceito de security e de seus requisitos. Embora não haja um entendimento unânime sobre tais requisitos, atualmente, é pacífico que em matéria de valores mobiliários deve prevalecer a substância e não a forma.

\subsection{O DIREITO EUROPEU E A CONCEITUAÇÃO DE VALOR MOBILIÁRIO}

Contrapondo-se ao direito norte-americano, os países europeus, em sua grande maioria, optaram, ao menos inicialmente, por adotar uma delimitação conceitual de valor mobiliário. No entanto, assim como a vertente norte-americana, a vertente europeia também possui suas limitações, as quais são abordadas por Phillipe Goutay (2000, p. 239) em artigo a respeito do conceito de valor mobiliário: "a dificuldade dos juristas em definir, com precisão, os valores mobiliários deve-se à insuficiência do critério orgânico: se todos os valores mobiliários são títulos negociáveis, a recíproca não é verdadeira”.

Na Itália, em um primeiro momento, a opção foi de não criar uma categoria específica de valor mobiliário. Considerava-se que o conceito de título de crédito seria suficiente para tutelar o que se pretendia.

Cesare Vivante foi o primeiro doutrinador italiano que se preocupou com o conceito de valores mobiliários, ainda que tangencialmente, ao buscar organizar de forma sistemática os documentos que incorporam direitos. Vivante designou esses documentos títulos de crédito e os definiu como documento necessário para se exercitar o direito literal e autônomo nele mencionado. Os títulos de crédito foram, então, divididos em categorias, sendo uma delas a dos títulos de crédito atributivos da qualidade de sócio. "Assim, no direito italiano, as primeiras noções do que hoje chamamos de valores mobiliários estavam ligadas ao conceito de títulos de crédito" (DIAS, 2005, p. 23).

Posteriormente, Ascarelli, estudando a variedade de títulos de crédito que surgiram de modo a viabilizar a capitalização a longo prazo de sociedade por ações, bem como a proliferação dos então chamados "títulos de créditos emitidos em massa", observou que esses títulos possuíam características específicas. Foi se percebendo, assim, que não eram poucas as diferenças entre os chamados títulos em massa e os títulos de crédito em geral. Estes últimos nascem de uma relação específica, individual e pessoal. Além disso, apesar 
de sua circulação ser possível, os títulos de crédito não são necessariamente fungíveis. Se forem causais, por exemplo, cada título emitido com base em uma causa é diferente. Já, no caso dos títulos em massa, a impessoalidade e a fungibilidade são elementos característicos.

As características específicas dos então chamados "títulos em massa" justificariam disciplinas legais distintas. Os títulos de crédito emitidos em massa precisavam, por exemplo, de regras que visassem à proteção do investidor.

Isso levou à separação dos títulos de crédito dos títulos em massa, que passariam a serem chamados valores mobiliários. Assim os autores italianos buscaram elementos e características próprias desses valores mobiliários, sem apresentar, entretanto, uma lista taxativa ou exemplificativa do que caracterizaria um valor mobiliário.

Essa forma conceitual de se definir quais os instrumentos que devem ser considerados valores mobiliários foi a adotada por muito tempo pela legislação italiana, conforme demonstra o artigo 18 da Lei $n^{\circ}$ 216/74, que assim definia valor mobiliário:

Per l'applicazione delle disposizioni di cui all'art. 18, per valore mobiliar $e^{\prime}$ da intendere ogni documento o certificato che direttamente o indirettamente rappresenti diritti in societa', associazioni, imprese o enti di qualsiasi tipo, ivi compresi i fondi di investimento italiani od esteri, ogni documento o certificato rappresentativo di un credito o di un interesse negoziabile e non; ogni documento o certificato rappresentativo di diritti relativi a beni materiali o proprieta' immobiliari, nonche' ogni documento o certificato idoneo a conferire diritti di acquisto di uno dei valori mobiliari sopra indicati ed ivi compresi i titoli emessi dagli enti di gestione fiduciaria di cui all'art. ${ }^{12}$

Interessante observar que em 2007, por meio do Decreto Legislativo 164, o qual alterou o Decreto Legislativo 58 de 1998 (Testo unico delle disposizioni in materia di intermediazione finanziaria), foi incorporada à definição legal de valor mobiliário uma

12 Tradução livre: Para aplicação das disposições deste artigo 18, entende-se por valor mobiliário todo documento ou certificado que direta ou indiretamente represente direitos em sociedade, associação, empresa ou ente de qualquer tipo, inclusive fundos de investimentos italianos ou estrangeiros, todo documento ou certificado que represente um crédito ou um interesse, negociável ou não, todo documento ou certificado que represente direitos relativos a bens materiais ou propriedades imobiliárias, assim como todo documento ou certificado idôneo a conferir direitos de aquisição de qualquer dos valores mobiliários supra indicados, inclusive de títulos emitidos por instituições de gestão fiduciária referidas no artigo. 
lista exemplificativa, embora mantida a definição conceitual baseada essencialmente na característica de serem negociáveis no mercado:

Per "valori mobiliari" si intendono categorie di valori che possono essere negoziati nel mercato dei capitali, quali ad esempio:

a) le azioni di società e altri titoli equivalenti ad azioni di società, di partnership o di altri soggetti e certificati di deposito azionario;

b) obbligazioni e altri titoli di debito, compresi i certificati di deposito relativi a tali titoli;

c) qualsiasi altro titolo normalmente negoziato che permette di acquisire o di vendere $i$ valori mobiliari indicati alle precedenti lettere;

d) qualsiasi altro titolo che comporta un regolamento in contanti determinato con riferimento ai valori mobiliari indicati alle precedenti lettere, a valute, a tassi di interesse, a rendimenti, a merci, a indici o a misure. ${ }^{13}$

Situação semelhante ocorre na Alemanha. A definição de valores mobiliários consta do Securities Prospectus Act alemão (Wertpapierprospektgesetz), nos termos do qual o fator decisivo para se definir valores mobiliários é a possibilidade de serem publicamente negociados. Esse normativo, porém, traz uma lista exemplificativa de valores mobiliários, que inclui ações, certificados representativos de ações, títulos de dívida e determinados derivativos.

A forma conceitual de definição de valores mobiliários, especialmente o aspecto da negociação no mercado, está presente, também, em outros países europeus, alguns dos quais, porém, estão mais próximos da vertente norte-americana na medida em que trazem uma lista não meramente exemplificativa de valores mobiliários. Esse é o caso, por exemplo, de Portugal. De acordo com o "Código dos Valores Mobiliários"14 português, são valores mobiliários:
a) As acções;
b) As obrigações;
c) Os títulos de participação;

13 Tradução livre: Por "valores mobiliários" entendem-se as categorias de valores negociáveis no mercado de capitais, como, por exemplo:

a) as ações de sociedades e outros títulos equivalentes às ações de sociedade, de parceria ou de outro tipo de sociedade, e certificados de depósito de ações;

b) obrigação e outro título de dívida, incluindo certificados de depósito relativos a tais títulos;

c) qualquer outro título geralmente negociado que possibilite a aquisição ou venda dos valores mobiliários indicados nas alíneas anteriores;

d) qualquer outro título que comporte uma liquidação em dinheiro, determinado com referência aos valores mobiliários indicados nas alíneas anteriores, a moedas, a taxa de juros, a rendimentos, a mercadorias, a índices ou a medidas.

${ }^{14}$ Publicado pelo Decreto-Lei n. ${ }^{\text {o } 357-A / 2007, ~ d e ~} 31$ de Outubro e alterado pelo Decreto-Lei n. ${ }^{\text { }} 211-\mathrm{A} / 2008$, de 3 de Novembro, pela Lei n. ${ }^{\circ}$ 28/2009, de 19 de Junho, pelo Decreto-Lei n. ${ }^{\circ}$ 185/2009, de 12 de Agosto, pelo Decreto-Lei n. ${ }^{\circ}$ 49/2010, de 19 de Maio, pelo Decreto-Lei n. ${ }^{\circ}$ 52/2010, de 26 de Maio, pelo Decreto-Lei n. ${ }^{\circ}$ 71/2010, de 18 de Junho, Lei n. ${ }^{\circ}$ 46/2011, de 24 de Junho e pelo Decreto-Lei n. ${ }^{\circ}$ 85/2011, de 29 de Junho. 


\begin{abstract}
d) As unidades de participação em instituições de investimento colectivo;
e) Os warrants autónomos;

f) Os direitos destacados dos valores mobiliários referidos nas alíneas a) a d), desde que o destaque abranja toda a emissão ou série ou esteja previsto no acto de emissão;

g) Outros documentos representativos de situações jurídicas homogéneas, desde que sejam susceptíveis de transmissão em mercado.
\end{abstract}

A Inglaterra também se aproxima mais da vertente norte-americana. O Banking Act inglês de 2009 traz uma relação do que se deve considerar valores mobiliários, dispondo que securities inclui tudo o que se encaixar em alguma das seguintes classes: (1) classe 1: ações; (2) classe 2: debêntures; (3) classe 3: warrants ou outros instrumentos que permitam os titulares adquirem algo na classe 1 ou 2; (4) classe 4: direitos que (a) sejam dados pelo tomador de um depósito, e (b) forme parte dos fundos próprios do tomador de depósitos para fins da seção 1 do capítulo 2 do Título V da Diretiva 2006/48/EC (relativa ao acesso à atividade das instituições de crédito e ao seu exercício).

\title{
3.3. O CONCEITO DE VALOR MOBILIÁRIO NO DIREITO COMUNITÁRIO EUROPEU
}

A definição de valores mobiliários apareceu pela primeira vez no direito comunitário europeu em 1977, na Recomendação da Comunidade Europeia 77/534, que instituiu um código europeu de conduta para negociações de valores mobiliários. Segundo o dispositivo desta Recomendação, caracterizam-se como valores mobiliários "todos os títulos negociados ou suscetíveis de serem negociados em um mercado organizado".

Mas foi em 1993, por meio da Diretiva 93/22/CEE do Conselho Europeu, que tratou dos serviços de investimento no domínio dos valores mobiliários ${ }^{15}$, que o Conselho estabeleceu o primeiro conceito de valor mobiliário no âmbito do direito comunitário. Em seu artigo $1^{\circ}$, item 4, a Diretiva Comunitária 22 definiu valores mobiliários conforme segue:

\footnotetext{
Valores mobiliários:

- ações e outros valores equivalentes a ações;

- obrigações e outros títulos de dívida negociáveis no mercado de capitais; e
}

\footnotetext{
15 Essa Diretiva tinha por objetivo estabelecer as condições em que as empresas de investimento e os bancos autorizados podiam prestar determinados serviços específicos ou estabelecer sucursais em outros Estados Membros, com base na autorização e supervisão do país de origem.
} 
- quaisquer outros valores habitualmente negociados que confiram o direito à aquisição desses valores mobiliários por subscrição ou troca ou que deem origem a uma liquidação em dinheiro, com exclusão dos meios de pagamento.

Como se pode observar, a definição de valor mobiliário adotada pela Diretiva 93/22/CEE, ao mesmo tempo em que não continha uma lista taxativa de valores mobiliários, também não se escusou de mencionar alguns deles expressamente.

A respeito da definição de valor mobiliário dada pela Diretiva 93/22/CEE, o legislador comunitário esclareceu que:

(...) a definição extremamente lata de valores mobiliários e de instrumentos do mercado monetário consagrada na presente diretiva é apenas válida para esta diretiva e que como tal em nada prejudica as diferentes definições de instrumento financeiro consagradas nas legislações nacionais para outros fins, nomeadamente de ordem fiscal (...)

Atualmente, a definição de valores mobiliários no direito comunitário europeu encontra-se na Diretiva dos Mercados de Instrumentos Financeiros (Diretiva 2004/39/CEE) do Conselho Europeu, que revogou a Diretiva 93/22/CEE. Essa Diretiva, conhecida pela sigla MiFID (Markets in Financial Instruments Directive) foi editada com o objetivo de determinar o grau de harmonização necessário para proporcionar aos investidores um elevado nível de proteção e permitir que as empresas de investimento prestem serviços em toda a Comunidade Europeia, no quadro de um mercado único, com base na supervisão do país de origem. O conceito de valor mobiliário constante dessa Diretiva é bem semelhante ao da Diretiva 93/22/CEE:

Artigo 4. Definições:

1. Para efeitos da presente diretiva, entende-se por:

(...)

Valores mobiliários: as categorias de valores que são negociáveis no mercado de capitais, com exceção dos meios de pagamento, como por exemplo:

a) Ações de sociedades e outros valores equivalentes a ações de sociedades, de sociedades de responsabilidade ilimitada (partnership) ou de outras entidades, bem como certificados de depósito de ações;

b) Obrigações ou outras formas de dívida titularizada, incluindo certificados de depósito desses títulos;

c) Quaisquer outros valores que confiram o direito à compra ou venda desses valores mobiliários ou que deem origem a uma liquidação em dinheiro, determinada por referência a valores mobiliários, divisas, taxas de juro ou de rendimento, mercadorias ou outros índices ou indicadores. 


\subsection{O CONCEITO DE VALOR MOBILIÁRIO NO DIREITO BRASILEIRO}

Como visto, os Estados Unidos e os países europeus optaram por seguir vertentes distintas no que diz respeito à conceituação de valor mobiliário. Enquanto o primeiro contornou as dificuldades de conceituação de valor mobiliário por meio da listagem de determinados títulos e instrumentos, a maioria dos países europeus adotou uma delimitação mais conceitual.

O conceito adotado atualmente pelo direito brasileiro aproxima-se do modelo norteamericano, como será visto a seguir.

A primeira menção sistemática a valores mobiliários no ordenamento jurídico brasileiro aparece na Lei $\mathrm{n}^{\circ} 4.728$, de 4 de julho de 1965, que, em seu artigo $2^{\circ}$, disciplinou as atribuições do Conselho Monetário Nacional e do Banco Central relativas ao mercado financeiro e de capitais:

\footnotetext{
Art. $2^{\circ}$. O Conselho Monetário Nacional e o Banco Central exercerão as suas atribuições legais relativas aos mercados financeiro e de capitais com a finalidade de:

I - facilitar o acesso do público a informações sobre os títulos ou valores mobiliários distribuídos no mercado e sobre as sociedade que os emitirem;

II - proteger os investidores contra emissões ilegais ou fraudulentas de títulos ou valores mobiliários;

III - evitar modalidades de fraude e manipulação destinadas a criar condições artificiais da demanda, oferta ou preço de títulos ou valores mobiliários distribuídos no mercado;

IV - assegurar a observância de práticas comerciais equitativas por todos aqueles que exerçam, profissionalmente, funções de intermediação na distribuição ou negociação de títulos ou valores mobiliários;

V - disciplinar a utilização do crédito no mercado de títulos ou valores mobiliários;

VI - regular o exercício da atividade corretora de títulos mobiliários e de câmbio.
}

Apesar de mencionar os valores mobiliários, a Lei nº 4.728/65 não se preocupou em defini-los. Tal definição foi introduzida no ordenamento jurídico brasileiro apenas com o advento da Lei $\mathrm{n}^{\circ}$ 6.385, de 7 de dezembro de 1976, criadora da Comissão de Valores Mobiliários. Essa lei não trouxe propriamente um conceito de valor mobiliário, mas sim 
uma lista taxativa dos instrumentos que, a partir de então, seriam considerados como valores mobiliários:

Art. $2^{\circ}$. São valores mobiliários sujeitos ao regime desta Lei:

I - as ações, partes beneficiárias e debêntures, os cupões desses títulos e os bônus de subscrição;

II - os certificados de depósitos de valores mobiliários;

III - outros títulos criados ou emitidos pelas sociedades anônimas, a critério do Conselho Monetário Nacional.

Como bem destaca Ary Oswaldo Mattos Filho (1985, p. 32):

A Lei criadora da Comissão de Valores Mobiliários não poderia imprudentemente repetir o expediente seguido pela Lei 4.728/65 de se utilizar da expressão valor mobiliário sem conceituá-la, sob pena da Comissão não ter definido seu campo de atuação.

A mesma lei explicitou, ainda, no parágrafo único de seu artigo $2^{\circ}$, os títulos excluídos do conceito de valor mobiliário:

Art. $2^{\circ}$. (...)

Parágrafo único. Excluem-se do regime desta Lei:

I - os títulos da dívida pública federal, estadual ou municipal;

II - os títulos cambiais de responsabilidade de instituição financeira, exceto as debêntures.

Cabe aqui trazer os ensinamentos de Arnoldo Wald (1985, p. 6) sobre a redação original do artigo $2^{\circ}$ da Lei $n^{\circ} 6.385 / 76$ :

Da simples leitura do art. $2^{\circ}$ da Lei 6.385/76, ficam patentes as dificuldades para que seja definido o exato alcance da expressão "valores mobiliários" em nosso sistema de direito positivo. Em primeiro lugar, verifica-se que o legislador não conceituou os valores mobiliários, preferindo, antes, enumerá-los. (...) Em segundo lugar, conforme pode ser percebido, a enumeração contida no art. $2^{\circ}$ da Lei $6.385 / 76$, é taxativa e não apenas exemplificativa, e ainda é tipicamente instrumental ou formal. Isto é, determinados títulos são considerados como "valores mobiliários" para os efeitos da Lei 6.385/76. Daí ser admissível, em princípio que outros valores mobiliários existam, embora em tal categoria não abrangidos para os fins da Lei $6.385 / 76$, isto é, para efeitos de sua fiscalização pela CVM e negociação no mercado de valores mobiliários, embora para os mencionados fins só sejam considerados como valores mobiliários os legalmente enumerados.

Com base na faculdade atribuída ao Conselho Monetário Nacional (CMN) pelo inciso III do artigo $2^{\circ}$ da Lei $n^{\circ}$ 6.385/76, este órgão resolveu, em 1990, por meio da Resolução $\mathrm{n}^{\mathrm{o}} 1.723$, considerar como valor mobiliário a nota promissória emitida por 
sociedade por ações, destinada à oferta pública - os commercial papers -, excetuando apenas aquelas emitidas por instituições financeiras, sociedades corretoras e distribuidoras de valores mobiliários e sociedades de arrendamento mercantil.

Posteriormente, em 1992, o CMN também passou a considerar valores mobiliários, por meio da Resolução $\mathrm{n}^{\circ} 1.907$, os seguintes títulos: direitos de subscrição de valores mobiliários; recibos de subscrição de valores mobiliários; opções de valores mobiliários e certificados de depósitos de ações.

Além das resoluções do $\mathrm{CMN}$, vários decretos, lei e medidas provisórias ampliaram o rol da Lei $n^{\circ} 6.385 / 76$, considerando outros instrumentos como valores mobiliários.

Todavia, como se tratava de um rol taxativo, qualquer instrumento ou título negociado que não se enquadrasse na listagem apresentada pela Lei ${ }^{\circ} 6.385 / 76$, conforme ampliada posteriormente pelas resoluções do $\mathrm{CMN}$, entre outras normas, escaparia da fiscalização da CVM.

A impropriedade desse sistema ficou evidente com os escândalos envolvendo empresas de captação de investimento em contratos de engorda de bois ${ }^{16}$. Conhecidos como contratos de boi gordo, esses contratos eram uma espécie de parceria pecuária, mas o comprador dos bois, que, na verdade, era o investidor, recebia uma parcela do valor da venda dos bois. As empresas que ofereciam essa "parceria" chegavam a prometer um rendimento de cerca de $40 \%$ quando do abate dos bois. O segredo de um rendimento tão atrativo foi descoberto depois que muitas vítimas caíram no golpe: essas empresas funcionavam como uma pirâmide, também conhecida como esquema de Ponzi. Isto é, os contratos vencidos eram pagos com o dinheiro da entrada de novos investidores. Quando os pagamentos superaram os novos investimentos, a pirâmide desmoronou.

Embora o caso dos bois tenha ficado mais conhecido, era comum também a oferta de investimentos em outros animais, como suínos e aves. Um dos casos célebres de pirâmide no Brasil é o caso da Avestruz Master, empresa goiana que emitia Cédulas de

16 Os principais escândalos foram protagonizados pelas Fazendas Reunidas Boi Gordo, que causaram a seus investidores um prejuízo de cerca de R \$ 4 bilhões, e a Gallus Agropecuária, que causou um prejuízo em torno de $\mathrm{R} \$ 200$ milhões. 
Produto Rural (as chamadas CPRs) que asseguravam aos seus adquirentes o direito de remuneração por meio de um compromisso de recompra das aves. O rendimento prometido chegava a 10\% ao mês. Quando faliu em 2004, a empresa deixou um prejuízo de mais de $\mathrm{R} \$ 2$ bilhões.

Portanto, conforme observa Nelson Eizirik (2011. p. 73), “o que nasceu como uma forma de capitalizar a atividade pecuária acabou se transformando em instrumento para a captação de poupança popular, com desvio de objetivos". Ademais, embora fossem utilizados como meios de se captar a poupança popular, esses contratos não estavam sujeitos à disciplina da Lei $n^{\circ} 6.385 / 76$, pois não se enquadravam no conceito de valores mobiliários.

Diante desse cenário, em regime de urgência, foi editada a Medida Provisória $n^{\circ}$ 1.637, de 8 de maio de 1998, convertida em 2001 na Lei $\mathrm{n}^{\circ} 10.198$, ampliando o rol de valores mobiliários, com o objetivo de abarcar títulos e contratos de investimento coletivo semelhantes aos contratos de boi gordo, conforme revela a exposição de motivos da Medida Provisória ${ }^{\circ}$ 1.637/98:

A possibilidade de vir a ser empregado esquema semelhante em diversos outros segmentos revela a necessidade de se adotar na legislação um conceito amplo, que abranja todas as modalidades de captação pública de poupança em que esteja presente a característica predominante de investimento coletivo, cujos rendimentos resultem do esforço de pessoas que não os investidores.

A Medida Provisória n ${ }^{\circ} 1.637 / 98$ classificou como valores mobiliários, sujeitos, portanto, ao regime da Lei $n^{\circ} 6.385 / 76$, quando ofertados publicamente, os títulos ou contratos de investimento coletivo, que gerem direito de participação, de parceria ou de remuneração, inclusive resultante de prestação de serviços, cujos rendimentos advêm do esforço do empreendedor ou de terceiros. Disposição essa semelhante à adotada pelo direito notre-americano em 1933 e cujos critérios foram definidos na década de 40, a partir do célebre caso Howey. Cabe observar, porém, que, embora inspirada no direito norteamericano, a nova definição constante da Medida Provisória n ${ }^{\circ}$ 1.637/98 traz os conceitos de participação, parceria e remuneração não presentes na "Howey definition". 
Desse modo, a CVM passou a ter competência para fiscalizar os referidos contratos, sujeitando-os ao prévio registro junto à autarquia no caso de distribuição pública desses instrumentos.

Nasceu então uma nova maneira de conceituar os valores mobiliários. Como destaca o jurista Nelson Eizirik (2001, p. 73): “A legislação brasileira até o advento da Medida Provisória $n^{\circ}$ 1.637/98, posteriormente convertida na Lei $n^{\circ} 10.198$, de 14.2.2001, não havia conceituado os valores mobiliários, os quais eram objeto de enumeração taxativa".

Vê-se aí uma transição no direito brasileiro da forma de conceituar valores mobiliários. Se anteriormente o legislador optava por uma forma restritiva, agora a conceituação abrangia não só uma lista de instrumentos, mas também quaisquer outros títulos que atendessem a determinadas características, ampliando-se assim o leque de abrangência dos valores mobiliários, tal qual o direito norte-americano e a sua conceituação de "security".

Em voto proferido em 2003, o então diretor da CVM Luiz Antonio de Sampaio Campos tece os seguintes comentários a respeito da evolução do conceito de valor mobiliário com o advento da Medida Provisória $\mathrm{n}^{\mathrm{o}} 1.637 / 98^{17}$ :

Esse novo conceito pode-se dizer que representou verdadeira revolução copérnica na regulação do mercado de valores mobiliários muito embora não se tenha atentado para toda a sua extensão, pois significa o abandono de uma concepção fechada de valor mobiliário, para a adoção de uma concepção funcional-instrumental do que seria valor mobiliário, acabando por alargar sobremaneira sua definição, bem como a competência da CVM.

Incorporou-se, então, na realidade brasileira substancialmente o conceito de security do direito norte-americano, sem maiores inovações, o que não significa nenhuma crítica, neste particular.

A mudança é um avanço e é bem-vinda, dado que o conceito de valor mobiliário do ponto de vista técnico-doutrinário não tem grande importância, havendo até mesmo dificuldade em se definir conceitualmente o que seja um valor mobiliário. O conceito que é relevante para o exame dos, digamos, valores mobiliários clássicos, está muito mais nos títulos de crédito do que no de valores mobiliários propriamente ditos, posto que as características efetivamente importantes são encontradas nos títulos de crédito.

17 Voto proferido no âmbito do Processo CVM nº RJ 2003/0499. 
Aquela visão de título de massa, de longo prazo, com homogeneidade incompatível com a diversidade das situações individuais, dotados de fungibilidade, que "coisifica" ou incorpora os direitos nele contidos, como exigência da negociabilidade, que deveria ser transmitido por tradição (em oposição à tradição por cessão), deixou de ser essencial para a existência de um valor mobiliário. Da mesma forma, a existência de um financiamento, da figura de um emitente e de um mercado primário para caracterizar um valor mobiliário também cedeu lugar.

A nota tonal no tocante a valor mobiliário passa, portanto, pelo esforço de captação da poupança pública com a conotação de investimento - ou mesmo especulação - por parte dos doadores dos recursos.

Em verdade, esta sempre foi a tônica da definição de valores mobiliários para fins de regulação pela CVM, muito embora não fosse assim tão explícita, não obstante fosse intuitiva.

Ela decorria, na verdade, da redação do art. $1^{\circ}$ da Lei $n^{\circ}$. 6.385/76, que ao se referir a valores mobiliários faz menção sempre à negociação no mercado, o que traz intrínseca a noção de negociação pública e não privada.

A transição verificada na forma de conceituação de valores mobiliários de restritiva ou formal para uma conceituação expansiva e conceitual consolidou-se por meio da edição da Lei $n^{\circ} 10.303 / 01$, a qual alterou o artigo $2^{\circ}$ da Lei $n^{\circ} 6.385 / 76$, refletindo o novo conceito introduzido pela Lei $\mathrm{n}^{\circ}$ 10.198/01.

Com as alterações trazidas pela Lei $\mathrm{n}^{\mathrm{o}} 10.303 / 01$, o artigo $2^{\circ}$ da Lei $\mathrm{n}^{\circ}$ 6.385/76 passou a vigorar com a seguinte redação:

Art. $2^{\circ}$ São valores mobiliários sujeitos ao regime desta Lei:

I - as ações, debêntures e bônus de subscrição;

II - os cupons, direitos, recibos de subscrição e certificados de desdobramento relativos aos valores mobiliários referidos no inciso II;

III - os certificados de depósito de valores mobiliários;

IV - as cédulas de debêntures;

$\mathrm{V}$ - as cotas de fundos de investimento em valores mobiliários ou de clubes de investimento em quaisquer ativos;

VI - as notas comerciais;

VII - os contratos futuros, de opções e outros derivativos, cujos ativos subjacentes sejam valores mobiliários;

VIII - outros contratos derivativos, independentemente dos ativos subjacentes; e

IX - quando ofertados publicamente, quaisquer outros títulos ou contratos de investimento coletivo, que gerem direito de participação, de parceria ou de remuneração, inclusive resultante de prestação de serviços, cujos rendimentos advêm do esforço do empreendedor ou de terceiros.

Logo, com a nova redação do artigo $2^{\circ}$ da Lei $n^{\circ} 6.385 / 76$, o legislador brasileiro adotou um estilo de caracterização de valores mobiliários semelhante ao adotado pelo legislador norte-americano. Ambos estabelecem, primeiro, uma lista enumerativa dos 
instrumentos que são qualificados como valores mobiliários. A seguir, adotam um conceito aberto para alcançar títulos não listados no dispositivo legal. Tendo em vista o dinamismo e a forma com que os mercados têm se desenvolvido, a adoção de conceitos de valores mobiliários abertos, de modo a inserir no conceito de valor mobiliário instrumentos complexos, e sofisticados criados pelos agentes do mercado, é uma tendência mundial.

No estabelecimento deste conceito mais amplo, o legislador brasileiro inseriu na lista taxativa uma definição genérica que inclui quaisquer títulos e contratos de investimento coletivo, sujeito a determinadas condições. Para se enquadrarem em tal definição, os títulos e contratos de investimento coletivo precisam gerar direito de participação, parceria ou remuneração, seus rendimentos devem advir de um esforço do empreendedor ou de terceiros e precisam, ainda, ser objeto de uma oferta pública.

Portanto, a inclusão de um tipo aberto tornou o conceito de valores mobiliários instrumental. Isso decorre do fato de a expressão "quando ofertados publicamente" (no inciso IX do artigo $2^{\circ}$ da Lei $n^{\circ}$ 6.385/76) indicar que um título, por mais que possua as características e os requisitos estabelecidos no referido dispositivo, somente passa a interessar o legislador dependendo de a quem é ofertado ou a forma em que é ofertado o referido título. Títulos idênticos podem ou não receber a condição de valores mobiliários, dependendo somente da forma como são negociados. Assim, para a classificação de um determinado ativo como valor mobiliário, é crucial definir se esse ativo está sendo ofertado, aos investidores, de forma pública ou privada. 


\section{A RELAÇÃo ENTRE TÍtulos de CRÉdito E VALORES MOBILIÁRIOS}

Como ensina o professor Fábio Konder Comparato (1981, p. 19):

Há uma pronunciada distinção funcional entre títulos de crédito e valores mobiliários. Os primeiros são instrumentos de pagamento ou de prestação (no sentido obrigacional), enquanto os segundos se apresentam como títulos de investimento ou de exercício do poder de controle empresarial.

Não obstante as diferenças profundas existentes entre esses dois institutos, a doutrina nacional inicialmente classificou os valores mobiliários na categoria de títulos de crédito. O renomado jurista Philomeno J. da Costa (1980, p. 111) chegou a conceituar valor mobiliário como "o título de crédito negociável, representativo de direito de sócio ou de mútuo a termo longo, chamado também de título de bolsa”. O mesmo ocorreu em outros países, inclusive na Itália. Como visto no Capítulo 3, os doutrinadores italianos, em um primeiro momento, não criaram uma categoria específica de valor mobiliário, pois entendiam que o conceito de título de crédito abrangeria tanto os títulos de crédito em si quanto os valores mobiliários.

A confusão entre os dois institutos se dá, muitas vezes, por existirem valores mobiliários que são também títulos de crédito, como as debêntures, e títulos de crédito que podem se tornar valores mobiliários, como a nota promissória. Porém, ao mesmo tempo, há títulos de crédito que não são aptos a desempenhar a função de valores mobiliários, em razão de sua estrutura, como é o caso do cheque e da duplicata. Como bem esclarece Modesto Carvalhosa (2009, p. 21):

\footnotetext{
Não há correlação entre título de crédito e valor mobiliário, embora possa este último, coincidentemente, revestir-se das características daquele (...) Os valores mobiliários apresentam como característica a sua negociação no sentido amplo do termo - no mercado de capitais. São direitos transacionados em massa, segundo regras legais e costumeiras aplicáveis aos respectivos mercados. Por outras palavras, os valores mobiliários são determinados direitos, habitualmente e reiteradamente, negociados por milhares de pessoas, segundo regras idênticas.
}

A diferenciação entre títulos de crédito e valores mobiliários fica ainda mais clara quando analisadas suas características essenciais. Como visto no Capítulo 2 deste trabalho, 
o título de crédito representa um documento necessário para o exercício do direito literal e autônomo nele mencionado, possuindo como requisitos essenciais a cartularidade, a literalidade e a autonomia. Já as características principais dos valores mobiliários é serem passíveis de negociação em massa e assegurarem direitos uniformes, e não necessariamente possuem os elementos próprios dos títulos de crédito.

A inexistência de uma relação de gênero e espécie entre os títulos de crédito e os valores mobiliários é destacada pelo professor Newton De Lucca em sua obra "A CambialExtrato" apresentada como tese de doutorado na Faculdade de Direito da Universidade de São Paulo em 1981 e publicada pela Revista dos Tribunais em 1985 (p. 148-149), que ressalta:

O conceito de "valores mobiliários" não possui qualquer liame lógico com o de "títulos de crédito". Podem os títulos de crédito, em alguns casos, assumir as feições de valores mobiliários e, vice-versa, estes poderão, concomitantemente, ser considerados como aqueles. Mas são dois sistemas, distintos, sem uma correspondência lógica entre ambos. Em outras palavras, o que torna um papel um título de crédito é algo completamente diverso daquilo que o faz considerá-lo, eventualmente, um valor mobiliário.

Os títulos de crédito e valores mobiliários possuem, ainda, diferentes funções econômicas. O jurista italiano Ferri destaca que os títulos de crédito são voltados à mobilização do crédito, enquanto os valores mobiliários funcionam como dissociação da propriedade. Ferri (1965, p. 36) assim contrapõe esses dois instrumentos:

Una disntizione normalmente seguita nella dottrina francese e che di recente è stata proposta anche tra noi, è quella tra titoli individuali (effects de commerce) e titoli di massa (valeurs mobilières), nel cui ambito vanno ricompresi le azioni e le obbligazioni della società, nonchè i tituli del debito pubblico, comprese in essi le carte di pubblico credito. La distinizione, pur basandosi essenzialmente su una diversità di funzionne economica [strumenti di mobilizzazione del credito, $i$ titoli individuali; strumenti di dissociazione tra proprietà (in senso economico) e controllo delle richezze, $i$ titoli di massa], assumerebbe rilievo nella determinazione del concetto giuridico di titolo di credito, in quanto nei titoli di massa da un lato il principio della incorporazione si attuerebbe con maggiore intensitá e, d'altro lato, il distacco tra il rapporto sottostante e il rapporto cartolare sarebbe talmente netto, da non consentire più alcuna influenza, neppure indiretta, del primo sul secondo, 
e da far qualificare com vendita di una res, anzichè come operazione di diversa natura (prstito, società) la stessa emissione del titolo. ${ }^{18}$

Dessa forma, diante de suas características e funções econômicas inteiramente distintas, não se pode confundir os títulos de crédito e os valores mobiliários.

${ }^{18}$ Tradução livre: Uma distinção normalmente feita pela doutrina francesa e que recentemente foi proposta também na Itália, é aquela entre títulos individuais (effects de commerce) e títulos de massa (valeurs mobilières), no âmbito dos quais são compreendidas as ações e as obrigações da sociedade, além dos títulos de débito público, incluídos nestes as cartas de crédito público [Nota: carta de crédito público, no direito italiano, é todo o papel emitido pelo governo que tem valor, como moeda e outros títulos ao portador emitidos pelo governo]. A distinção, mesmo baseando-se essencialmente em uma diferença de função econômica [instrumentos de mobilização do crédito, os títulos individuais; e instrumentos de dissociação entre propriedade (em sentido econômico) e controle de riquezas, os títulos de massa], teria importância na determinação do conceito jurídico de título de crédito, enquanto nos títulos de massa, por um lado, o princípio da incorporação atuaria com maior intensidade e, por outro lado, o descolamento entre a relação fundamental e a relação cartular seria tão claro que não permitiria mais nenhuma influência, nem mesmo indireta, do primeiro sobre o segundo, fazendo com que a emissão do título seja qualificada como venda de uma coisa (objeto móvel ou imóvel), ao invés de uma operação de natureza diversa (empréstimo, sociedade). 


\section{NEGOCIAÇÃO DE VALORES MOBILIÁRIOS}

\subsection{OFERTA PÚBLICA DE VALORES MOBILIÁRIOS}

Como visto, o conceito de oferta pública é de fundamental importância para a própria conceituação de valor mobiliário. Um título ou contrato de investimento coletivo apenas poderá ser considerado um valor mobiliário quando ofertado publicamente, a menos, é claro, que se enquadre nos incisos I a VIII do artigo $2^{\circ}$ da Lei $n^{\circ} 6.385 / 76$.

Precisar o conceito de oferta pública é também crucial para se delimitar o campo de atuação da CVM. Nenhuma emissão pública de valores mobiliários pode ser realizada no Brasil sem o prévio registro na CVM, conforme determina a Lei ${ }^{\circ} 6.385 / 76$. O registro tem por objetivo proteger os investidores, sendo um mecanismo para lhes assegurar o acesso a informações claras e precisas sobre a companhia emissora e os valores mobiliários emitidos.

Mas quando exatamente há uma oferta pública? Esse é um conceito de difícil precisão, genérica e vagamente delimitado pela legislação e doutrina brasileiras. É certo que o fator determinante para se distinguir uma oferta pública de uma oferta privada são seus destinatários - a oferta pública é aquela destinada ao público. Porém, para uma definição mais precisa, é necessário determinar o que seria o público para esse fím.

Público deriva do latim publicus, que significa "relativo, pertencente ou destinado ao povo, à coletividade" (CUNHA, 2007, p. 646). O grande pensador italiano, Norberto Bobbio, em um de seus textos clássicos, "Estado, Governo, Sociedade", aborda a dicotomia entre público e privado. Segundo Norberto Bobbio (1987, p. 15-28), a dicotomia público/privado tem dois significados distintos. A primeira é a dicotomia segundo a qual "público" se refere aquilo que pertence ao povo, a res publica, sendo que por povo deve se entender "uma sociedade mantida junta, mais que por um vínculo jurídico, pela utilitatis comunione", e "privado" se refere ao que pertence aos membros singulares. Na segunda acepção da dicotomia, “por 'público’ se entende aquilo que é manifesto, aberto ao público, feito diante de espectadores, e por 'privado', ao contrário, aquilo que se diz ou faz num restrito círculo de pessoas e, no limite, em segredo". 
A oferta pública de valores mobiliários carrega as duas acepções do termo público. Em uma oferta pública, as informações são amplamente divulgadas, com a finalidade de se proteger o interesse público, a coletividade. Partindo desses conceitos gerais, os ordenamentos jurídicos vêm buscando delimitar o significado de oferta pública.

Nos Estados Unidos, assim como ocorreu com o conceito de valor mobiliário, coube à jurisprudência e à Securities Exchange Commission (SEC) definir o conceito de oferta pública. O conceito de oferta pública e oferta privada de valores mobiliários começou a ser debatido nos Estados Unidos a partir da edição do Securities Act, em 1933. Conforme observa Haroldo Malheiros Duclerc Verçosa (1997, p. 76) em artigo sobre o regime jurídico das ofertas públicas:

\begin{abstract}
A história do Securities Act, de 1933, e das outras leis que versam sobre o mesmo tema está ligada ao reconhecimento da necessidade de uma proteção especial para o investidor, frente aos diversos mecanismos de captação de poupanças e o conceito de security, como tal trabalhado pela jurisprudência das cortes norte-americanas, resultou em grande efetividade daquela proteção, quando se tratasse de oferta pública.
\end{abstract}

Nesse contexto, o Securities Act determina o registro perante a SEC de qualquer oferta pública de valor mobiliário. Por outro lado, isenta desse registro as operações de colocação privada de valores mobiliários, estabelecendo que a exigência de registro não se aplica a transações "que não envolvem qualquer oferta pública". Todavia, o Securities Act não definiu os critérios que caracterizariam tal oferta. O House Report de 1933 apenas esclareceu que tal isenção permitiria aos emissores realizarem uma venda específica ou isolada de valores mobiliários quando não houvesse uma necessidade prática de se aplicar a exigência de registro de oferta pública.

Diante dessa omissão, inúmeras divergências surgiram envolvendo as diferenças entre oferta pública e privada. Nesse contexto, os tribunais foram chamados a se pronunciar a respeito do que seria uma oferta pública. O caso paradigmático (leading case) envolvendo essa questão foi o processo SEC v. Ralston Purina Co. ${ }^{19}$, julgado pela Suprema Corte em 1953, vinte anos após a edição do Securities Act. Ralston Purina possuía na época cerca de 7.000 empregados, espalhados pelos Estados Unidos e Canadá. Em linha com sua política de incentivar a aquisição por seus funcionários de ações da companhia,

19346 U.S. 119 (1953). 
Ralston Purina emitiu aproximadamente US\$ 2 milhões em valores mobiliários não registrados entre 1947 e 1951. Diante desse número expressivo de ações, passou-se a discutir se essa oferta não deveria ter sido registrada na SEC. A companhia sustentava que a oferta enquadrava-se na exceção prevista no Securities Act, uma vez que era destinada apenas a empregados chave ("key employees"). No entanto, a Suprema Corte não concordou com o argumento da companhia e concluiu que a isenção prevista para oferta privada deveria ser interpretada à luz dos objetivos do Securities Act - a proteção de investidores através do "disclosure" de todas as informações necessárias para uma decisão de investimento consciente.

Embora as decisões dos tribunais norte-americanos no caso SEC v. Ralston Purina Co e em outros diversos casos similares trouxeram determinados parâmetros para avaliar se determinada oferta seria pública ou privada, tais parâmetros ainda eram vagos e incertos. Nesse contexto, a SEC promulgou em 1974 a Rule 146, com o objetivo de delinear critérios objetivos para determinar se uma oferta é pública ou privada, tendo em vista dois elementos principais: a garantia de acesso à informação necessária e a capacidade do investidor alvo da oferta de avaliar tal informação.

Nesse sentido, a Rule 146 proibia propagandas generalizadas e determinava (a) que o emissor deveria se certificar da sofisticação dos investidores, de sua capacidade de defenderem-se por conta própria ("fend for themselves"), ou seja, de que possuíam conhecimento e experiência necessária para utilizar as informações fornecidas, avaliar os riscos envolvidos e tomar decisões de investimento consciente; e (b) que o investidor deveria ter acesso às informações necessárias para essa análise. Além disso, a Rule 146 estabelecia um número de compradores máximo para que uma oferta fosse considerada privada, talvez a contribuição mais relevante dessa norma para esclarecer as dúvidas em torno dos conceitos de oferta pública e privada. De acordo com tal regra, não deveria haver mais de 35 pessoas em qualquer período de 12 meses consecutivos que adquirissem valores mobiliários de determinado emissor no âmbito de uma oferta privada. Interessante notar que a Rule 146 excluía do cômputo desse limite qualquer pessoa que tivesse adquirido determinados valores mobiliários por um valor acima de US\$250.000,00.

Em 1982, a Rule 146 foi substituída pela Regulation D, composta de uma série de normas que estabelecem os critérios para determinada oferta de valores mobiliários estar 
isenta do registro perante a SEC (ou seja, ser considerada uma oferta privada). A Regulation D estabelece três exceções, previstas em três normas distintas (Rules 504, 505 e 506).

As exceções previstas na Regulation $D$, que permitem a distribuição de valores mobiliários sem a necessidade de registro na SEC, estão relacionadas a três elementos principais: (a) a qualificação dos ofertados e sua capacidade para avaliar os riscos envolvidos no investimento; (b) o acesso às informações necessárias para essa análise; e (c) a forma pela qual os valores mobiliários são ofertados.

Recentemente, em abril de 2012, foi promulgado o Jumpstart Our Business Startups Act, mais conhecido como JOBS Act, que promoveu diversas alterações na regulamentação do mercado de capitais norte-americano, com o objetivo de aumentar a capacidade de pequenas empresas captarem recursos no mercado de capitais. Uma dessas mudanças diz respeito às exceções previstas na Rule 506 da Regulation D. O JOBS Act determina que a SEC altere a Rule 506 de forma que as proibições a "general solicitation" ou "general advertising" previstas na Rule 502(c) da Regulation D não se apliquem a ofertas e vendas de valores mobiliários nos termos da Rule 506, desde que todos os compradores sejam "accredited investors" 20 . O JOBS Act também exige que a SEC reveja a Rule 144A de forma que os valores mobiliários vendidos sob essa norma sejam ofertados não apenas a investidores qualificados, inclusive por meio de "general solicitation" ou "general advertising", desde que tais valores mobiliários sejam apenas vendidos a pessoas que a companhia razoavelmente acredite serem investidores qualificados (qualified institutional buyers - QIBs). Tais mudanças reforçam o foco nos destinatários, destacando ainda mais o aspecto instrumental do conceito de oferta pública.

A Diretiva 2003/71/CE do Parlamento Europeu e Conselho, de 4 de novembro de 2003, também foca nos destinatários ao definir oferta pública. De acordo com essa Diretiva, a oferta pública consiste em "uma comunicação ao público, independentemente da forma e dos meios por ela assumidos, que apresente informações suficientes sobre as condições da oferta e os valores mobiliários em questão, a fim de permitir a um investidor

${ }^{20}$ A definição de "accredited investors" encontra-se na Rule 501 da Regulation D. São exemplos de "accredited investors": bancos, seguradoras, companhias de investimento, fundos de pensão, os diretores, conselheiros e sócios da empresa vendedora dos valores mobiliários e pessoa física com patrimônio superior a US\$ 1 milhão, entre outros. 
decidir sobre a aquisição ou subscrição desses valores mobiliários”. No entanto, essa não nos parece ser a definição mais adequada, pois a apresentação de informações sobre a oferta deve ser uma consequência e não a causa de uma oferta pública. Essa definição, porém, foi acolhida em diversos países europeus, como é o caso da França, Espanha e Itália.

No caso da Itália, entretanto, é interessante observar as decisões dos tribunais italianos a respeito do assunto. Segundo a jurisprudência italiana, para que uma oferta de valores mobiliários seja considerada pública deve ser destinada a uma coletividade indeterminada de pessoas:

Sollecitazione all'investimento - Nozione e caratteristiche - Differenze con la negoziazione individuale - Conseguenze in tema di inapplicabilità dell'obbligo di consegna del prospetto informativo.

La distinzione tra sollecitazione all'investimento e semplice negoziazione (quest'ultima non soggetta all'obbligo di prospetto informativo) si pone essenzialmente sul piano dei destinatari dell'offerta, che, nel primo caso (sollecitazione) è una collettività indeterminata di persone, cui l'acquisto è proposto a condizioni standard uguali per tutti, mentre, nel secondo caso è il singolo cliente (o anche una pluralità di soggetti, purché determinati), cui i titoli vengono offerti di volta in volta, alle condizioni determinate dalle esigenze dell'acquirente e dal momento in cui l'operazione è eseguita. Solo nel caso di sollecitazione all'investimento è previsto dalla legge l'obbligo di predisporre e pubblicare il prospetto informativo (art. 94 D.L.vo 58/98). (Franco Benassi) (riproduzione riservata) Tribunale Piacenza 30 novembre $2010^{21} 22$

No Brasil, a caracterização das ofertas públicas está prevista no artigo 19 da Lei $\mathrm{n}^{\circ}$ 6.385/76, que, conforme observa Nelson Eizirik (2008, p. 141), "ao invés de estabelecer uma distinção conceitual entre a distribuição privada e a distribuição pública de valores mobiliários, limitou-se a enunciar algumas hipóteses em que esta última vem a se caracterizar". O $\S 1^{\circ}$ desse artigo define como atos de distribuição pública aqueles que importem a venda, promessa de venda, oferta à venda ou subscrição, aceitação de pedido de venda ou subscrição de valores mobiliários, quando praticadas por companhia emissora,

\footnotetext{
${ }^{21}$ Tradução livre: Solicitação de investimento - Noção e características - Diferença em relação à negociação individual - Consequência em relação à inaplicabilidade da obrigação de apresentar o prospecto informativo. A distinção entre solicitação de investimento e simples negociação (sendo que esta última não acarreta a obrigação do prospecto informativo) se põe essencialmente sobre o plano dos destinatários da oferta, que, no primeiro caso (solicitação) é um conjunto indeterminado de pessoas, cuja aquisição é proposta a condições "standard", iguais para todos, enquanto, no segundo caso, é cada cliente (ou mesmo uma pluralidade de sujeitos, desde que determinados), cujos títulos são oferecidos, a cada vez, a condições determinadas das exigências do adquirente e a partir do momento no qual a operação é executada. Somente no caso de solicitação de investimento é previsto na lei a obrigação de fornecer e publicar o prospecto informativo (art. 94 D.L.vo 58/98). (Franco Benassi) (reprodução reservada) Tribunal de Piacenza 30 de novembro de 2010.

${ }^{22}$ Disponível em http://www.ilcaso.it/finanziario/mdf-3.php. Acesso em 13 de agosto de 2012.
} 
seus fundadores ou as pessoas a ela equiparadas. Já o $\S 3^{\circ}$ desse mesmo dispositivo traz um rol de atos que caracterizam a oferta pública:

(i) a utilização de listas ou boletins de venda ou subscrição, folhetos, prospectos ou anúncios destinados ao público;

(ii) procura de subscritores ou adquirentes para os títulos por meio de empregados, agentes ou corretores;

(iii) a negociação feita em loja, escritório ou estabelecimento aberto ao público, ou com a utilização dos serviços públicos de comunicação.

Durante quase três décadas, os dispositivos acima citadas formavam o conjunto de regras aplicável à realização de ofertas públicas no Brasil. Em 2003, com a edição da Instrução $n^{\circ}$ 400, de 29 de dezembro de 2003 (“Instrução CVM n 400"), pela CVM, foram regulamentadas as disposições do artigo 19 da Lei $n^{\circ}$ 6.385/76, estabelecendo-se um novo conjunto de regras para ofertas públicas primárias e secundárias. Há, ainda, regras específicas disciplinando a oferta pública de determinados valores mobiliários. É o caso das notas promissórias, cuja oferta pública é disciplinada nas Instruções CVM n ${ }^{\circ}$ 134/90 e 155/91, bem como dos Certificados de Recebíveis Imobiliários, cuja oferta é disciplinada na Instrução CVM 414/04.

A Instrução CVM n 400 estabelece que determinada oferta seja considerada pública quando ocorrerem os seguintes fatos, isoladamente ou em conjunto:

(i) a utilização de listas ou boletins de venda ou subscrição, folhetos, prospectos ou anúncios, destinados ao público, por qualquer meio ou forma;

(ii) a procura, no todo ou em parte, de subscritores ou adquirentes indeterminados para os valores mobiliários, mesmo que realizada através de comunicações padronizadas endereçadas a destinatários individualmente identificados, por meio de empregados, representantes, agentes ou quaisquer pessoas naturais ou jurídicas, integrantes ou não do sistema de distribuição de valores mobiliários, ou, ainda, se em desconformidade 
com o previsto na Instrução, a consulta sobre a viabilidade da oferta ou a coleta de intenções de investimento junto a subscritores ou adquirentes indeterminados;

(iii) a negociação feita em loja, escritório ou estabelecimento aberto ao público destinada, no todo ou em parte, a subscritores ou adquirentes indeterminados; ou

(iv) a utilização de publicidade, oral ou escrita, cartas, anúncios, avisos, especialmente através de meios de comunicação de massa ou eletrônicos (páginas ou documentos na rede mundial ou outras redes abertas de computadores e correio eletrônico), entendendo-se como tal qualquer forma de comunicação dirigida ao público em geral com o fim de promover, diretamente ou através de terceiros que atuem por conta do ofertante ou da emissora, a subscrição ou alienação de valores mobiliários.

O conceito de público em geral, acima referido, é dado pelo artigo $3^{\circ}, \S 1^{\circ}$ da Instrução. Significa uma classe, categoria ou grupo de pessoas, mesmo que individualizadas nesta qualidade, com exceção daqueles que tenham uma prévia relação comercial, creditícia, societária ou trabalhista, estreita e habitual, com a emissora dos valores mobiliários.

Ademais, a Instrução $\mathrm{CVM} \mathrm{n}^{\circ} 400$ permite que a CVM dispense o registro da oferta pública dirigida exclusivamente a investidores qualificados, desde que os subscritores ou adquirentes, confirme o caso, declarem que têm conhecimento e experiência em finanças e negócios suficientes para avaliar os riscos e o conteúdo da oferta e que são capazes de assumir tais riscos, bem como que tiveram amplo acesso às informações que julgaram necessárias e suficientes para a decisão de investimento.

A Instrução CVM n ${ }^{\circ} 400$ contém, assim, critérios mais detalhados que a Lei ${ }^{\circ}$ 6.385/76 com relação ao que constitui oferta pública de valores mobiliários. Em ambos os normativos, a definição do que constitui a oferta pública é baseada principalmente no método utilizado para sua distribuição. Referida Instrução traz, ainda, elementos subjetivos, especialmente ao estabelecer as hipóteses de dispensa de registro. A caracterização de um ato de distribuição como público, gera a necessidade de prévio registro e autorização por parte de CVM. 
Com o objetivo de esclarecer alguns dos critérios constantes da Lei $\mathrm{n}^{\circ}$ 6.385/76 e da Instrução CVM n ${ }^{\circ}$ 400, em 30 de setembro de 2005, a CVM editou dois pareceres de orientação, Pareceres nºs 32 e 33.

O primeiro trata do uso de Internet como meio de comunicação em uma oferta pública de valores mobiliários. Há tempos o mercado já clamava por um posicionamento da CVM sobre esse tema, o que veio com a emissão do Parecer $n^{\circ} 32$. A CVM considera que ao se usar a Internet como meio de divulgação a oferta de valores mobiliários deve ser considerada, via de regra, como pública, o que está em linha com a Instrução CVM nº 400.

Todavia, a adoção de medidas preventivas exemplificadas no Parecer $n^{\circ} 32$ poderão descaracterizar as ofertas como públicas se:

(i) o patrocinador da página da Internet (information provider) tenha tomado medidas efetivas para impedir que o público em geral tenha acesso ao conteúdo da página;

(ii) não haja divulgação da página ao público pelo patrocinador da página da Internet, por exemplo, por meio de correio eletrônico não solicitado, em mecanismos de busca, salas de discussão, ou por propaganda em páginas na Internet ou revistas; e

(iii) exista indicação direta ou indireta, mas suficientemente clara, de que a página não foi criada para o público em geral.

Os fatores acima não precisam coexistir para que seja descaracterizada como pública a oferta de valores mobiliários realizada por meio da Internet. Outros fatores, que não os expressamente mencionados no Parecer $n^{\circ} 32$, podem ser levados em conta para que se considere a oferta como pública. A CVM apurará a partir de caso concreto a configuração como pública de oferta de valores mobiliários feita por meio da Internet.

Por fim, o Parecer $n^{\circ} 32$ esclarece que o uso da Internet para o exercício das atividades de mediação ou corretagem de operações com valores mobiliários, distribuição de emissões no mercado ou aquisições de valores mobiliários para revenda por conta própria depende de prévia autorização da CVM. 
Já o Parecer no 33 explicita o entendimento da CVM acerca da caracterização de uma oferta como pública no Brasil, quando a emissora dos valores mobiliários se localiza em outra jurisdição, e da necessidade de registro perante a CVM dos agentes que pretendem exercer a intermediação, no País, de operações com valores mobiliários emitidos e negociados em outras jurisdições, para investidores residentes no Brasil. Em linhas gerais, segundo o referido parecer:

(i) não há isenção específica no tocante à necessidade de registro de oferta de valores mobiliários estrangeiros no Brasil, caso tal oferta seja caracterizada como oferta pública;

(ii) somente integrantes do sistema nacional de distribuição, devidamente registrados, estão autorizados a oferecer serviços de intermediação de operações com valores mobiliários no Brasil;

(iii) entretanto, no caso de valores mobiliários emitidos no exterior, não haveria irregularidade desde que a atividade de prospecção dos investidores seja realizada no exterior, e a operação a ser intermediada não se caracterize como oferta pública no Brasil.

O Parecer $n^{\circ} 33$ traz, ainda, um importante esclarecimento a respeito do conceito de oferta pública. Estabelece que, para que uma oferta de valores mobiliários seja considerada pública, não basta que sejam utilizados os meios de comunicação previstos no artigo $19, \S$ $3^{\circ}$, da Lei $n^{\circ} 6.385 / 76$. É preciso que tais meios de comunicação sejam utilizados “com o propósito de atingir o público em geral” ou, ainda que não haja essa intenção, que os meios de comunicação utilizados "permitam atingir esse público e as cautelas devidas para que isso não ocorra deixem de ser tomadas".

Pode-se concluir, assim, que, no Brasil, a oferta pública de valores mobiliários caracteriza-se por elementos objetivos e subjetivos. Os elementos objetivos referem-se aos meios de distribuição dos valores mobiliários. Como visto, a Lei $\mathrm{n}^{\circ}$ 6.385/76 e a Instrução $\mathrm{CVM} \mathrm{n}^{\circ} 400$ trazem exemplos de atos de distribuição que caracterizam a oferta pública. Já os elementos subjetivos dizem respeito aos destinatários de tais atos. Conforme conclui Nelson Eizirik (2008, p. 146), “a oferta pública caracteriza-se, em síntese, por ser dirigida 
à generalidade de indivíduos, ou seja, por ser direcionada a pessoas indeterminadas, não individualizadas". Ademais, para se caracterizar uma determinada oferta como pública é preciso verificar a situação dos destinatários, isto é, seu grau de sofisticação e se tiveram acesso às informações relativas à companhia e aos valores mobiliários em questão, como será analisado em mais detalhe no item 5.3 abaixo.

\subsection{OFERTA PÚBLICA COM ESFORÇOS RESTRITOS}

A Instrução CVM 476 instituiu no ordenamento jurídico brasileiro o conceito de "oferta pública com esforços restritos". Essa modalidade de oferta de valores mobiliários foi criada à luz de modelos adotados em outras jurisdições e tem por objetivo facilitar o acesso das empresas ao mercado de capitais mediante a redução de custos e prazos.

A Instrução CVM 476 contém uma lista taxativa dos títulos que podem ser objeto de ofertas públicas com esforços restritos, os quais são os seguintes: notas comerciais, CCBs que não sejam de responsabilidade de instituição financeira, debêntures não-conversíveis ou não-permutáveis por ações, cotas de fundos de investimento fechados, certificados de recebíveis imobiliários ou do agronegócio, letras financeiras, desde que não relacionadas a operações ativas vinculadas, certificados de direitos creditórios do agronegócio, cédulas de produto rural - financeiras que não sejam de responsabilidade de instituição financeira, e warrants agropecuários.

Dentre as principais características e requisitos desse tipo de oferta pública, destacam-se as seguintes:

(i) devem ser destinadas exclusivamente a investidores qualificados ${ }^{23} \mathrm{e}$ intermediadas por integrantes do sistema de distribuição de valores mobiliários;

23 O conceito de investidor qualificado encontra-se previsto no artigo 109 da Instrução CVM 409, que considera investidores qualificados: (i) instituições financeiras; (ii) companhias seguradoras e sociedades de capitalização; (iii) entidades abertas e fechadas de previdência complementar; (iv) pessoas físicas ou jurídicas que possuam investimentos financeiros em valor superior a $\mathrm{R} \$ 300.000,00$ (trezentos mil reais) e que, adicionalmente, atestem por escrito sua condição de investidor qualificado mediante termo próprio, de acordo com o Anexo I; (v) fundos de investimento destinados exclusivamente a investidores qualificados; (vi) administradores de carteira e consultores de valores mobiliários autorizados pela CVM, em relação a seus recursos próprios; (vii) regimes próprios de previdência social instituídos pela União, pelos Estados, pelo Distrito Federal ou por Municípios. 
(ii) são direcionadas a um público restrito, sendo que até cinquenta investidores podem ser procurados e apenas vinte podem subscrever ou adquirir os valores mobiliários ofertados;

(iii) estão automaticamente dispensadas de registro de distribuição;

(iv) os subscritores ou adquirentes deverão fornecer, por escrito, uma declaração atestando sua ciência de que (a) a oferta não foi registrada na CVM; e (b) os títulos e valores mobiliários ofertados estão sujeitos às restrições de negociação previstas na própria Instrução CVM 476;

(v) a CVM deve ser informada do encerramento da oferta;

(vi) é vedado ao ofertante implementar outra oferta pública distribuída com esforços restritos da mesma espécie de títulos e valores mobiliários do mesmo emissor dentro do prazo de quatro meses contados da data do encerramento da oferta, a menos que a nova oferta seja submetida a registro na CVM;

(vii) os valores mobiliários objeto de oferta apenas podem ser negociados no mercado secundário após o prazo de noventa dias contados de sua subscrição ou aquisição pelo investidor;

(viii) a negociação no mercado secundário só pode ocorrer entre investidores qualificados; e

(ix) o emissor do valor mobiliário é obrigado a cumprir determinadas obrigações relacionadas à divulgação de informações (principalmente aquelas que dizem respeito ao preparo e divulgação de informações financeiras).

Diante de suas características, pode-se dizer que a oferta pública com esforços restritos representa uma modalidade mais flexível de oferta de valores mobiliários quando comparada com a oferta pública tradicional regulada pela Instrução CVM no 400. Essa flexibilidade não dispensou, contudo, a intervenção da CVM como órgão fiscalizador do mercado de capitais. Ou seja, a despeito de a oferta pública com esforços restritos ser 
direcionada exclusivamente a investidores qualificados, entendeu a CVM que a proteção regulatória a essa modalidade de captação de poupança ainda seria necessária.

\subsection{OFERTA PRIVADA}

As ofertas privadas de valores mobiliários, ao contrário do que ocorre com as ofertas públicas, não requerem registro na CVM. "Nessas situações não se justifica a exigência de prévio registro da oferta, dada a inexistência de qualquer benefício para o interesse público" (EIZIRIK, 2008, p. 137).

No entanto, o legislador e autoridades reguladoras brasileiras apenas se preocuparam em definir os atos de distribuição pública, sem ao menos estabelecer critérios objetivos para a caracterização de tais atos. Não há no ordenamento jurídico brasileiro uma definição legal ou regulatória do que seria uma oferta privada de valores mobiliários, tampouco critérios que permitam uma clara distinção entre atos de oferta pública e de oferta privada.

Embora não exista tal definição em nosso ordenamento jurídico, a Exposição de Motivos da Lei $\mathrm{n}^{\circ}$ 6.385/76, principal diploma legal sobre o mercado de capitais, reconhece a possibilidade de uma "emissão particular" de valores mobiliários:

Apenas a emissão pública (isto é, a emissão oferecida publicamente) está sujeita a registro. Não se aplica essa norma à emissão particular, como é o caso da emissão negociada com um grupo reduzido de investidores, que tenham acesso ao tipo de informação que o registro visa a divulgar. Se estes, porém, adquirem a emissão com o fim de a colocar no mercado, mediante oferta pública, estão sujeitos às mesmas restrições que a companhia emissora.

A ausência de elementos suficientes para uma clara distinção entre ofertas públicas e privadas acaba por gerar uma insegurança jurídica entre os participantes do mercado, uma vez que uma oferta aparentemente privada pode vir a ser considerada pela CVM como pública. De forma a evitar tal insegurança, há sistemas jurídicos que adotam critérios claros de distinção entre essas duas formas de oferta de valores mobiliários. É o caso, por exemplo, do sistema norte-americano. 
Como visto no item 5.1 deste capítulo, nos Estados Unidos há critérios específicos para a definição de oferta privada. Outros sistemas jurídicos também adotam conceitos semelhantes, muito embora sem critérios tão objetivos, como o sistema norte-americano.

Ao contrário do ordenamento jurídico norte-americano, nosso ordenamento jurídico não contém nem ao menos uma definição de oferta privada. O legislador brasileiro, assim como as autoridades reguladoras, apenas se preocupou em definir o que seria uma oferta pública e, ainda assim, sem estabelecer critérios objetivos para sua caracterização.

Embora não haja uma definição de oferta privada, a partir do conceito de oferta pública, o qual já foi analisado neste trabalho, pode-se chegar a critérios que caracterizariam uma oferta privada. Não é de hoje que a doutrina, inspirada em modelos adotados em outras jurisdições (principalmente no modelo norte-americano), busca identificar parâmetros para a caracterização do instituto. Tais parâmetros consideram a conceituação de oferta pública no ordenamento jurídico nacional para, a contrario sensu, identificar os contornos do conceito de oferta privada.

Nesse sentido, o jurista Nelson Eizirik (2008, p. 150) observa que "para a caracterização da distribuição como pública ou privada, embora sejam relevantes os meios utilizados na colocação dos títulos, o elemento essencial e decisivo refere-se à situação dos ofertados”. Eizirik acrescenta, ainda, que:

Daí decorre que, independentemente dos meios utilizados no processo de oferta, determinada distribuição de valores mobiliários não deve ser considerada pública se os ofertados, além de pessoas certas ou determinadas, forem investidores sofisticados e, em função de suas relações com a companhia emissora ou do fato de deterem "poder de barganha" perante esta, tiverem acesso ao mesmo tipo de informação que seria exigido em decorrência do registro.

A caracterização de uma oferta de valores mobiliários, como privada, deve levar, assim, em conta elementos objetivos e subjetivos. No tocante aos elementos objetivos, entende-se que (i) a oferta deve ser realizada pelo próprio emissor e/ou ofertante sem a utilização de meios de divulgação ao público em geral; (ii) a oferta deve ser direcionada a um número limitado de investidores; e (iii) a negociação do valor mobiliário deve ocorrer em estabelecimentos não abertos ao público em geral. 
Os elementos subjetivos, por sua vez, dizem respeito aos destinatários da oferta. O primeiro deles refere-se ao grau de sofisticação dos investidores, isto é, busca-se conhecer se o investidor é capaz de avaliar os riscos do investimento que lhe é oferecido, bem como se tem experiência em questões relacionadas a finanças e negócios empresariais em geral.

O segundo elemento subjetivo está relacionado à disponibilidade de informações sobre a sociedade emissora e o respectivo valor mobiliário ofertado, ou seja, deve ser avaliado se o investidor teve acesso a informações equiparáveis àquelas que seriam disponibilizadas no contexto de uma oferta pública de tal forma a caracterizar uma decisão de investimento consciente e bem informada.

Dado o caráter instrumental do registro de uma oferta de valores mobiliários, se os destinatários da oferta forem investidores sofisticados, capazes de avaliar o risco e o mérito do investimento, e tiverem acesso a informações que lhe permitam uma tomada de decisão consciente, não há razão para se obrigar a companhia emissora a efetuar o registro da oferta perante a CVM. 


\section{PROTEÇÃO DOS INVESTIDORES NO MERCADO DE CAPITAIS}

A disciplina jurídica do mercado de capitais brasileiro foi desenvolvida sob a égide do princípio intitulado de "full disclosure". O full disclosure representa o dever de divulgação de informações relativas aos valores mobiliários negociados no mercado e a seus emissores, de modo claro e transparente, para permitir que os investidores possam tomar decisões de investimento de forma consciente e informada.

O princípio do full disclosure encontra suas origens no direito inglês e no direito norte-americano. Como relembra Louis Loss (1985, p. 73), já em 1844 o parlamento inglês impôs na lei das sociedades (Companies Act) a obrigação de emissão de prospecto, como condição para a negociação de valores mobiliários. Essa lei introduziu o princípio de divulgação de informações mínimas, de forma obrigatória, por meio da emissão de um prospecto, pela companhia que oferecesse valores mobiliários ao público. Ressalta-se que a exigência é apenas de divulgação da informação, sem qualquer análise de mérito das informações divulgadas.

Nos Estados Unidos, por sua vez, o princípio do full disclosure foi contemplado, pela primeira vez, em uma lei federal, em 1933, com inspiração na lei inglesa. Antes disso, já havia, porém, reivindicações por uma maior transparência na emissão e negociação de valores mobiliários. Em 1914, Louis D. Brandeis, Ministro da Suprema Corte, sustentou, em sua obra Other People's Money And How the Bankers Use It, editada naquele ano, que a publicidade era o melhor remédio para as enfermidades sociais e industriais em geral, bem como para os grandes ganhos dos "underwriters". É dele a frase "Sunlight is said to be the best of disinfectants; electric light the most efficient policeman". 24 Tais reivindicações ganharam ainda mais força a partir de 1929, quando a Bolsa de Valores de Nova York quebrou em decorrência de fraudes e abusos cometidos face, principalmente, a falta de veracidade da situação financeira das companhias e de seus títulos, e a excessiva liberdade de mecanismos privados de negociação de valores mobiliários.

A crise de 1929 acarretou uma profunda depressão econômica e uma perda generalizada de confiança no mercado de capitais. Com o objetivo de reprimir os abusos

\footnotetext{
${ }^{24}$ Tradução livre: A luz do sol é o melhor desinfetante, a luz elétrica o mais eficiente policial.
} 
que culminaram na quebra da Bolsa de Nova York e restaurar a confiança dos investidores, foram editados o Securities Act em 1933 e o Securities Exchange Act em 1934, que tornaram mandatória uma ampla divulgação de informações sobre as companhias emissoras e os valores mobiliários negociados no mercado, bem como seu prévio registro junto à Securities and Exchange Comission (SEC). Salienta-se que o Estado, ao conceder o registro de emissão dos valores mobiliários, não procede a uma análise de mérito dos elementos de informação prestados pelo emissor, tampouco assume a posição de garantidor da qualidade das informações prestadas ${ }^{25}$.

No Brasil, a elaboração da Lei $n^{\circ} 6.385 / 76$ foi fundamentalmente norteada pelo princípio do full disclosure. Ao longo de todo o texto dessa lei é salientada a importância do acesso, pelos investidores, a informações sobre os valores mobiliários negociados no mercado e as companhias que os tenham emitido. O dever de informar ainda está previsto expressamente na Lei das Sociedades por Ações (Lei nº 6.404/76).

As atribuições da CVM também foram definidas à luz de tal princípio, tendo sido atribuída a essa autarquia a responsabilidade por assegurar o acesso do público a informações sobre os valores mobiliários e seus emissores, e veicular as informações relativas ao mercado às pessoas que dele participem. Conforme exposto no item 5.1 do Capítulo 5, o registro de uma oferta pública de valores mobiliários, perante a CVM, tem justamente por objetivo assegurar aos investidores o acesso a informações claras e precisas sobre a companhia emissora e os valores mobiliários emitidos.

Nas palavras de Nelson Eizirik (1987, p. 126):

A função pública na regulação do mercado de capitais é o de promover a ampla transparência de informações (full disclosure), de sorte que, uma vez bem informados, os investidores poderão decidir, com conhecimento de causa, sobre as suas aplicações financeiras no mercado de capitais.

\footnotetext{
${ }^{25}$ O Securities Act de 1933 estabelece, em sua Seção 23 (“Unlawful Representations”), que o fato de uma declaração de registro (registration statement) para um valor mobiliário ter sido protocolada ou estar em efeito não significa que a SEC considere tal declaração verdadeira e exata, ou que não contenha uma declaração inverídica ou omita um fato relevante, tampouco significa que a SEC realizou uma análise de mérito da declaração de registro.
} 
A legislação e regulação do mercado de capitais brasileiro foram construídas, dessa forma, sob a concepção de que a garantia da divulgação de informações, somada à ausência de manipulação do mercado, seria suficiente para seu bom funcionamento.

Entretanto, muito embora o princípio do full disclosure seja, sem dúvida, um dos princípios basilares do mercado de capitais, é preciso observar que tal sistema possui fragilidades. Luiz Gastão Paes de Barros Leães (1974, p. 56) aborda, em artigo sobre o conceito de valores mobiliários no direito norte-americano, essas fragilidades:

O grande número dos dispositivos legais, porém, procuram impor a prática da "total revelação de informações" (full disclosure). O propósito desses comandos é o de possibilitar o investidor dispor das informações necessárias para tomar decisões criteriosas com relação a seus investimentos, e assegurar também que essas informações sejam verdadeiras. Não procura questionar a solidez do empreendimento, nem proibir o investidor de realizar uma má escolha, mas apenas e tão somente fornecer-lhe informações pertinentes para exame. Sequer tenta assegurar que as informações sejam de fato examinadas pelo investidor. A sua ação parte do princípio, por longo tempo reconhecido no direito americano, de que uma pessoa deve estar habilitada a realizar um negócio com pleno conhecimento dos fatos, se bem que a boa ou má escolha fique reservada exclusivamente à sua vontade livre.

Cabe indagar, assim, se a divulgação obrigatória de informações aos investidores é medida suficiente para assegurar sua proteção. Não resta dúvida sobre a vital importância do acesso dos investidores a informações sobre os riscos inerentes aos valores mobiliários em que pretendem investir. No entanto, não basta que o investidor esteja ciente de tais riscos, é preciso que tenha condições de avaliá-los adequadamente, o que nem sempre ocorre.

Como será exposto na segunda parte deste trabalho, dada a complexidade da avaliação de tais riscos, há casos em que o acesso à informação não é o bastante. Esse é o caso da CCB. 
SEGUNDA PARTE

CÉDULA DE CRÉDITO BANCÁRIO 


\title{
1. INCURSÃO HISTÓRICA SOBRE A CRIAÇÃO DA CCB
}

Conforme mencionado na introdução deste trabalho, a criação da $\mathrm{CCB}$ atendeu às demandas das instituições financeiras por um mecanismo mais ágil e eficiente de cobrança de crédito, que propiciasse uma maior segurança e, ao mesmo tempo, a flexibilidade necessária para operações de crédito bancário. É o que observa Humberto Theodoro Júnior (2005, p. 16):

\begin{abstract}
A criação da cédula de crédito veio ao encontro da necessidade premente e urgente de inovação no cenário nacional à época, em que os financiamentos bancários se tornavam cada dia mais caros e restritos, devido à insegurança e instabilidade das decisões dos pretórios nacionais que fragilizavam os vínculos contratuais. As instituições financeiras vinham enfrentando grande resistência de devedores inadimplentes, tomadores de crédito sob a difundida modalidade de cheque especial ou contrato de abertura de crédito, que, sem retornar sequer o capital recebido ou a parte incontroversa de suas dívidas, postergavam anos a fio as ações executivas sob a alegação de ausência de título executivo líquido, certo e exigível.
\end{abstract}

À época da criação das CCBs, as operações de crédito eram instrumentalizadas especialmente por meio de notas promissórias e contratos de abertura de crédito, pelos quais o banco se obriga a manter à disposição do cliente certa quantia em dinheiro por tempo determinado ou não, normalmente conjugado a uma conta corrente. Porém, havia grande incerteza acerca da utilização de tais instrumentos diante de decisões de tribunais que ora negavam e ora decidiam a favor da força executiva dos contratos de abertura de crédito e das notas promissórias vinculadas a tais contratos.

O extinto Primeiro Tribunal de Alçada Civil de São Paulo editou, em 1987, a Súmula $\mathrm{n}^{\circ} 11$ determinado que "o contrato de conta corrente, feito por estabelecimento bancário a correntista, assinado por duas testemunhas e acompanhado do extrato da conta corrente respectiva, é título executivo extrajudicial".

O mesmo posicionamento foi adotado pelo também extinto Tribunal de Alçada Cível do Estado do Rio de Janeiro por meio da edição da Súmula no 35 em 1997, segundo a qual "são títulos executivos extrajudiciais os contratos de abertura de crédito assinados pelo correntista e por duas testemunhas, acompanhados dos extratos que exponham totalmente a evolução da conta corrente, acusando o saldo devedor final". 
Já o extinto Tribunal de Alçada do Rio Grande do Sul, assim como outros tribunais, ora entendia pela força executiva do contrato de abertura de crédito, ora não, como mostram as ementas abaixo:

Contrato de crédito em conta corrente. Iliquidez. O contrato de abertura de crédito em conta corrente, mesmo aliado aos extratos, de emissão unilateral e que não especificam as parcelas neles constantes, contaminam a liquidez do pedido. Ademais, não é dado às instituições financeiras criar seus próprios títulos. (Apelação Cível No 198070260, Décima Segunda Câmara Cível, Tribunal de Alçada do RS, Relator: Cézar Tasso Gomes, Julgado em 15/10/1998)

Execução. Contrato de abertura de crédito em conta corrente. O contrato de abertura de crédito em conta-corrente bancária, assinado por duas testemunhas, é título executivo extrajudicial desde que acompanhado de planilha demonstrativa da relação débito-crédito de todo o período negocial de início a fim, sem lacunas ou claros na sua evolução. Apelação improvida. (Apelação Cível No 197287808, Vigésima Câmara Cível, Tribunal de Alçada do RS, Relator: Ilton Carlos Dellandrea, Julgado em 10/11/1998)

Em 1999, a matéria foi apreciada pela Segunda Seção do Superior Tribunal de Justiça em sede de embargos de divergência a respeito da executividade de contratos de abertura de crédito $^{26}$. O Relator, Ministro Ruy Rosado de Aguiar, não reconheceu a executividade dos contratos de abertura de crédito, mesmo que subscrito pelo devedor e assinado por duas testemunhas e ainda que a execução fosse instruída com o extrato da conta e da especificação do crédito, sob o fundamento de que os contratos de abertura de crédito, os quais são elaborados unilateralmente pela instituição financeira, não são dotados dos atributos de liquidez e certeza.

Essa decisão deu origem à Súmula 233, publicada no Diário de Justiça em 8 de fevereiro de 2000, cujo enunciado possui o seguinte teor: "O contrato de abertura de crédito, ainda que acompanhado de extrato de conta corrente, não é título executivo”.

Ao negar a força executiva dos contratos de abertura de crédito, o STJ suscitou uma nova controvérsia: a nota promissória atrelada a contrato de abertura de crédito estaria "contaminada" pela iliquidez desse contrato? O STJ pôs fim a essa controvérsia ao editar a Súmula de número 258, publicada no Diário de Justiça em 24 de setembro de 2001,

26 Embargos de Divergência em Recurso Especial 148.290-RS. 
segundo a qual "A nota promissória vinculada a contrato de abertura de crédito não goza de autonomia em razão da iliquidez do título que a originou".

Diante dessa posição do STJ, tanto o contrato de abertura de crédito como a nota promissória atrelada a esse contrato deixaram definitivamente de serem instrumentos adequados para amparar as operações de crédito. Como observa Humberto Theodoro Júnior (2003, p. 17):

O Sistema Financeiro Nacional ficou órfão, desamparado, de instrumento jurídico que conferisse celeridade e segurança às volumosas transações que envolvem abertura de crédito, cheque especial ou crédito rotativo, sob pena de se restringirem e encarecerem ainda mais as linhas de financiamento.

Nesse contexto, as instituições financeiras clamavam por um título de crédito adequado para instrumentalizar e garantir as operações de crédito.

As instituições financeiras buscavam, ainda, a criação de um instrumento suficientemente eficaz para a realização de operações financeiras mais complexas, notadamente aquelas cuja estrutura não permitisse o cálculo prévio do valor da dívida. Essa impossibilidade de antecipação do quantum debeatur, que pode ser verificada, por exemplo, nas operações de crédito rotativo ${ }^{27}$, impedia que as instituições financeiras utilizassem quase que a totalidade dos títulos de crédito existentes à época. Em regra, a indicação do exato valor a ser pago é um dos requisitos dos títulos de crédito. ${ }^{28}$ Apenas com esse instrumento os bancos poderiam cumprir de forma eficaz sua função primordial: a geração de liquidez ao Sistema Financeiro Nacional.

Diante desse cenário, decidiu o Poder Executivo intervir. Com a edição da Medida Provisória $n^{\circ} 1.925 / 99$, criando a $\mathrm{CCB}$, o governo procurou garantir celeridade às soluções de conflitos envolvendo créditos bancários e, com isso, oferecer meios para a redução dos custos de crédito no Brasil. Com as CCBs, as instituições financeiras passaram, enfim, a ter a mobilidade necessária para realizar suas variadas atividades creditícias, incluindo operações de crédito rotativo.

\footnotetext{
27 Operações de crédito rotativo, grosso modo, são linhas de crédito com limite preestabelecido.

28 Havia apenas algumas exceções no direito brasileiro. Tratava-se, porém, de títulos de crédito voltados ao financiamento de determinados setores, como a Cédula de Crédito Rural.
} 
Ao encaminhar o texto da primeira edição da Medida Provisória $n^{\circ}$ 1.925/99 ao Presidente da República, o então Ministro Pedro Malan destacou o momento econômico vivido e justificou a necessidade de se dotar o mercado financeiro de liquidez:

Há muito tempo, o mercado financeiro necessita de um título de crédito que espelhe com realidade as relações jurídicas entre as instituições financeiras e seus clientes e que, principalmente, torne a formalização das diversas operações de crédito menos onerosa e complicada, conferindo maior flexibilidade e agilidade na mobilização do crédito, cumprindo, assim, com a extraordinária função econômica para a qual foi concebida a primeira cédula, inspirada na legislação Italiana, especificamente na 'Cambiale Agrária', utilizada na concessão de crédito para a atividade agropecuária, matéria que cuidou o Decreto-lei real 1.508, de 24 de julho de 1927 (que disciplinou o crédito agrário), regulamentado pelo Decreto Ministerial de 23 de janeiro de 1928, decreto esse que foi convertido na Legge 5 luglio 1928, n. 1.760.

A criação da $\mathrm{CCB}$ conferiu, assim, às instituições financeiras a segurança e a celeridade que necessitavam, como destaca Gerson Luiz Carlos Branco (2008, p. 120):

A cédula de crédito bancário é criada em novembro de 1999 por meio da MedProv 1.925/99, editada pelo governo federal como uma medida para dar segurança às instituições financeiras, permitindo a estas que representem seus créditos por meio de título que possibilita a cobrança de tudo o que então a jurisprudência vinha negando: capitalização mensal de juros, cumulação de comissão de permanência com juros remuneratórios e cláusula penal, executoriedade de contratos ilíquidos e títulos cujo valor é formado a partir de extratos elaborados unilateralmente etc. 


\section{CONCEITO E ELEMENTOS CARACTERÍSTICOS}

\subsection{CONCEITO}

Conforme definiu o artigo $1^{\circ}$ da Medida Provisória $n^{\circ} 1.925 / 99$, instituidora da CCB, definição essa atualmente constante do artigo 26 da Lei n ${ }^{\circ}$ 10.931/04, "a Cédula de Crédito Bancário é título de crédito emitido, por pessoa física ou jurídica, em favor de instituição financeira ou de entidade a esta equiparada, representando promessa de pagamento em dinheiro, decorrente de operação de crédito, de qualquer modalidade".

A CCB é, portanto, um título de crédito, constituindo uma promessa de pagamento tal qual uma nota promissória, com a diferença de que o tomador é sempre uma instituição financeira. A sua criação destinou-se justamente a oferecer ao mercado um título de crédito dotado de força executiva extrajudicial que pudesse facilitar e fomentar as relações de crédito bancário.

Em caso de inadimplência do emissor, sua cobrança pelo credor dá-se diretamente pela via da execução judicial por quantia certa, ou seja, sem a necessidade de um processo próprio de conhecimento.

A exequibilidade das CCBs foi, inclusive, recentemente ratificada pela Quarta Turma do Superior Tribunal de Justiça, no Recurso Especial n ${ }^{\circ}$ 1.103.523-PR, julgado em 10 de abril de 2012. Conforme claramente expôs o Ministro Luis Felipe Salomão, relator do recurso, "a Cédula de Crédito Bancário é título executivo extrajudicial representativo de operações de crédito de qualquer natureza".

A respeito da natureza jurídica da $\mathrm{CCB}$, vale, ainda, citar os seguintes trechos da Exposição de Motivos dada à Medida Provisória n ${ }^{\circ} 1.925 / 99$ pelo então Ministro da Fazenda Sr. Pedro Malan:

(...) Por essa razão, o projeto esforça-se por aplicar corretamente a terminologia da linguagem jurídica, definindo, claramente, a sua característica de título de crédito, mantendo a tradição consagrada no direito brasileiro, da literalidade (existência de uma obrigação 
independente da relação fundamental) ${ }^{29}$; da autonomia (as obrigações cambiais são autônomas e independentes uma das outras) como definido no art. 43 do Decreto n. ${ }^{\circ} 2.044$, de 31 de dezembro de 1908 - Lei interna, princípio esse que foi mantido na Lei Uniforme, no art. $7 .^{\circ}$ do Anexo I; e da cartularidade (documento necessário ao exercício do direito que nele se contém, pois na clássica definição de Vivante, 'título de crédito' é o documento necessário para o exercício do direito literal e autônomo nele mencionado, definição essa acolhida mutatis mutandi pelo direito brasileiro, ex vi do disposto no art. 1.508 do Código Civil), conferindolhe liquidez e certeza e, enfim, possibilitando a sua transferência por endosso, total ou parcialmente, podendo constar, inclusive, o valor pela qual será transferida.

(...) Em razão da exigência de forma certa e determinada, isto é, da autosuficiência da cédula de crédito bancário como documento de legitimação e prova dos direitos cambiários, preocupou-se o art. $4 .^{\circ}$ do projeto em indicar os requisitos essenciais que ela deve conter, requisitos esses que inspiraram-se, como não poderia deixar de ser, nos mesmos princípios já consagrados nos diplomas de regência das cédulas de crédito rural e industrial.

Nas palavras de Humberto Theodoro Junior (2003, p. 50), "não há, pois, a menor sombra de dúvida de que a cédula de crédito bancário é título de crédito com força executiva, criado por lei, portanto típico, que representa direito certo, líquido e exigível por expressa disposição legal”.

"Como título de crédito, a cédula é dotada, por expressa previsão de lei, de cartularidade ("documento escrito", artigo 29, § 2), literalidade (declarações “essenciais"), artigo 29 e parágrafos) e circularidade, podendo conter cláusula à ordem, transmitindo-se por endosso (artigo 29, IV e $\S 1^{\circ}$ )", conforme observa Luiz Gastão Paes de Barros Leães (2010, p. 224). Como visto no Capítulo 2 da primeira parte deste trabalho, cartularidade consiste na materialização do direito no documento. Já por literalidade entende-se que vale nos títulos apenas o que nele está escrito. A circularidade será tratada quando se examinar a circulação da CCB no item 2.4 a seguir.

A CCB trata-se, ainda, de título causal, uma vez que deve se referir a determinada obrigação creditícia. De acordo com Paulo Salvador Frontini (2000, p. 59):

A cédula de crédito bancário surge com natureza jurídica explicitamente enunciada. É título de crédito (art. $1^{\circ}$ ), da espécie promessa de pagamento

\footnotetext{
${ }^{29}$ Note-se, data vênia, que a definição de literalidade não está correta. Por literalidade, entende-se que só vale no título o que nele está escrito. "A existência de uma obrigação independente da relação fundamental" seria a definição de outra característica dos títulos de crédito, a abstração.
} 
(art. $4^{\circ}$, II), qualifica-se como título executivo extrajudicial (art. $3^{\circ}$ ), tem como relação jurídica subjacente (causa) operação de crédito de qualquer modalidade $\left(\operatorname{art.~} 1^{\circ}\right.$ ) e consubstancia obrigação líquida (art. $3^{\circ}$ ) de pagamento em dinheiro em favor de instituição financeira ou de entidade a esta equiparada, integrantes, estas, do Sistema Financeiro Nacional (art. $\left.1^{\circ}\right)$.

\subsection{REQUISITOS}

A cédula de crédito possui requisitos formais e substanciais. O artigo 29 da Lei ${ }^{\circ}$ 10.931/04 elenca os requisitos formais da CCB, sendo eles: (i) a denominação "Cédula de Crédito Bancário"; (ii) a promessa do emitente de pagar a dívida em dinheiro, certa, líquida e exigível no seu vencimento ou, no caso de dívida oriunda de contrato de abertura de crédito bancário, a promessa do emitente de pagar a dívida em dinheiro, certa, líquida e exigível, correspondente ao crédito utilizado; (iii) a data e o lugar do pagamento da dívida e, no caso de pagamento parcelado, as datas e os valores de cada prestação, ou os critérios para essa determinação; (iv) o nome da instituição credora, podendo conter cláusula à ordem; (v) a data e o lugar de sua emissão; e (vi) a assinatura do emitente e, se for o caso, do terceiro garantidor da obrigação, ou de seus respectivos mandatários.

Já o artigo 28 do mesmo diploma legal dispõe sobre as condições contratuais que podem ser pactuadas no próprio título, estando entre elas os juros sobre a dívida, os critérios de atualização monetária, eventuais multas e penalidades contratuais, hipóteses de vencimento antecipado da dívida, critérios de apuração e de ressarcimento, pelo emitente ou por terceiro garantidor, dos custos de cobrança da dívida, incluindo honorários advocatícios, eventuais garantias, entre outras obrigações do credor e do devedor.

Conforme observa Gerson Luiz Carlos Branco (2008, p. 127), “dois artigos distintos, com finalidades distintas e que tornam a cédula um instrumento híbrido: tem todas as características de um contrato e ao mesmo tempo tem características próprias dos títulos de crédito." Acrescenta, ainda, "o contrato não é subjacente, mas inerente à cédula".

\subsection{GARANTIAS QUE PODEM SER ATRELADAS À CCB}

A possibilidade de serem emitidas com ou sem garantia é um dos elementos característicos comuns a todas as cédulas de crédito, incluindo a CCB. 
A CCB admite tanto garantias reais (por exemplo, hipoteca, penhor) como fidejussórias (aval, fiança). Quando tais garantias são outorgadas, as formalidades, a elas aplicáveis, deverão ser observadas.

A garantia pode ser constituída na própria CCB ou em documento separado. No segundo caso, é preciso fazer menção a essa circunstância na cédula. $O$ bem constitutivo da garantia deverá ser descrito e individualizado de modo que permita sua fácil identificação. Alternativamente, poderá ser feita remissão a documento ou certidão expedida por entidade competente referente ao bem constitutivo da garantia, que deverá integrar a cédula.

\title{
2.4. A CIRCULAÇÃO DA CCB
}

"A CCB apresenta a vantagem de permitir a livre circulação dos direitos creditórios nela consubstanciados, o que confere maior liquidez ao Sistema Financeiro Nacional" (CARVALHOSA, EIZIRIK, 2010, p. 543).

A respeito da circulação da CCB, o artigo $29, \S 1^{\circ}$ da Lei $n^{\circ} 10.931 / 04$ estabelece que:

\begin{abstract}
A Cédula de Crédito Bancário será transferível mediante endosso em preto, ao qual se aplicarão, no que couberem, as normas do direito cambiário, caso em que o endossatário, mesmo não sendo instituição financeira ou entidade a ela equiparada, poderá exercer todos os direitos por ela conferidos, inclusive cobrar os juros e demais encargos na forma pactuada na Cédula.
\end{abstract}

O endosso consiste, em regra, na simples assinatura do beneficiário no verso do título (o que, aliás, explica a palavra "endosso", de in dorso, nas costas). Porém, a Lei Uniforme de Genebra, ratificada pelo Decreto $n^{\circ}$ 57.663/1966, admite que o endosso seja lançado no título ou em "folha anexa" (artigo 13).

O endosso pode ser feito de duas formas: com a designação do endossatário ou sem essa designação. No primeiro caso, o endosso é chamado nominativo ou endosso em preto. Já na segunda hipótese, onde a simples assinatura do endossante é suficiente para a transferência do título, o endosso é chamado de endosso em branco. 
No caso da CCB, conforme previsto na Lei ${ }^{\circ} 10.931 / 04$, o endosso deve ser em preto, devendo o endossatário ser identificado. Uma vez verificado o endosso, o endossatário, mesmo não sendo instituição financeira ou entidade a ela equiparada, passará a figurar como credor na relação de crédito representada pela $\mathrm{CCB}$, podendo exercer todos os direitos e prerrogativas inerentes a tal condição, conforme descritos no título.

A transferência da CCB pode ser feita com ou sem coobrigação da instituição financeira. Caso haja coobrigação da instituição financeira, esta garantirá a liquidez do título.

Como bem destaca Luiz Alfredo Paulin (2008, p. 35), "a facilidade com que a CCB pode ser transferida é uma das grandes vantagens desse título frente, por exemplo, a um contrato de mútuo". Isso porque, ao contrário do que ocorre com a $\mathrm{CCB}$, um contrato de mútuo ou outros instrumentos similares apenas podem ser transferidos mediante cessão civil, prevista nos artigos 286 e seguintes do Código Civil. Essa cessão, nos termos do artigo 290 do Código Civil, apenas será eficaz em relação ao devedor se a ele for notificada, exigência essa que encontra grandes obstáculos em termos práticos. Não obstante a existência de tais obstáculos, o Superior Tribunal de Justiça entende que a cessão de crédito, de fato, não vale em relação ao devedor, senão quando a ele notificada. ${ }^{30}$ Dessa forma, não havendo a notificação, se o devedor pagar ao antigo credor, a dívida deve ser considerada quitada, restando ao novo credor apenas buscar seus direitos contra o cedente do crédito.

Outra grande desvantagem da cessão civil em relação à transferência de títulos de crédito está no fato de que o devedor pode opor ao cessionário as exceções que lhe competirem, bem como as que, no momento em que veio a ter conhecimento da cessão, tinha contra o cedente (artigo 294 do Código Civil). Ou seja, o devedor poderá opor contra o cessionário todas as formas de defesa de que dispunha contra o cedente, ao tempo que teve conhecimento da cessão.

$30 \quad$ AgRg no Resp 1.171.617/PR, $3^{\mathrm{a}}$ Turma, DJ 22.2.2011, Resp 588.321/MS, $3^{\mathrm{a}}$ Turma, DJ 5.9.2005. 
A respeito dessa desvantagem da cessão civil, vale recordar as lições de Ascarelli (1999, p. 29-30):

\begin{abstract}
Não se pode negar que a circulação do crédito será impossível ou, quando menos, praticamente difícil se o direito creditório continuar ligado aos que forem os sujeitos originários da relação jurídica, ao de que nasceu e ao conjunto das relações havidas entre aqueles sujeitos. Com efeito, então, o direito do cessionário ficará subordinado à existência do direito do cedente e passível das exceções oponíveis a este, exceções cujo alcance, e algumas vezes, cuja própria existência, o cessionário dificilmente poderá avaliar.
\end{abstract}

Já a CCB, ao contrário da cessão civil, é um instrumento adequado para a efetiva circulação do crédito, uma vez que sua transferência pode ser feita por um simples endosso e independe de notificação do devedor. Além disso, a CCB, como título de crédito, é dotada de autonomia, não podendo ser opostos ao portador do título as exceções existentes contra seus antigos portadores. 


\section{MODELOS DE NEGOCIAÇÃO DA CCB}

Como visto no capítulo anterior, as CCBs são transferíveis mediante endosso em preto, ou seja, com a designação do endossatário. Sendo assim, como podem ser feitas as negociações de CCBs?

A solução está na informatização dos títulos de crédito. Conforme já foi mencionado, a Lei Uniforme de Genebra admite que o endosso seja lançado no título ou em folha anexa. Diante dessa faculdade, é possível que o endosso seja feito de forma eletrônica, em sistemas de registro e liquidação financeira. O termo de registro eletrônico, no qual é identificado o destinatário, produz os efeitos de um endosso em preto.

Em parecer a respeito da negociação de CCB na Cetip, o professor Luiz Gastão Paes de Barros Leães (2010, p. 221) trata do endosso eletrônico:

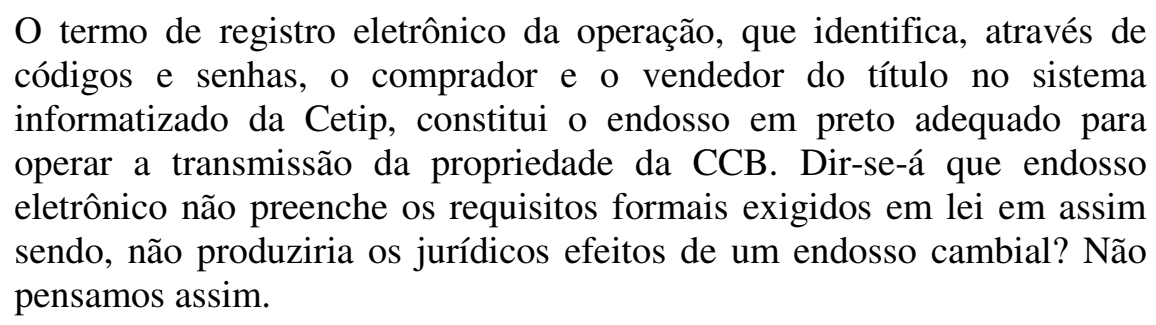

Esclarecida a questão do endosso, cabe analisar as formas de negociação de CCBs. São três as possíveis formas:

(i) negociação em bolsa de valores;

(ii) negociação em mercado de balcão organizado; e

(iii) negociação em mercado de balcão não-organizado.

A negociação em bolsa apenas é possível se as CCBs forem objeto de uma oferta pública. Já a negociação em mercados de balcão organizado ou não-organizado pode ocorrer no caso de oferta pública com esforços restritos ou oferta privada. A Instrução CVM 476, que trata da oferta pública com esforços restritos, prevê que os valores 
mobiliários ofertados de acordo com essa Instrução poderão ser negociados nos mercados de balcão organizado e não-organizado, mas não em bolsa.

O mercado de balcão, em contraposição ao de bolsa, é aquele em que as entidades autorizadas a nele operar fazem-no diretamente entre si, ou diretamente com seus clientes, sem um mecanismo centralizado e compulsório de formação de preços.

No Brasil, há duas espécies de mercado de balcão: o mercado de balcão organizado e o mercado de balcão não-organizado. O primeiro é aquele sujeito a mecanismos de autoregulamentação e autorizadas a funcionar pela CVM. "A caracterização do mercado de balcão organizado envolve algum tipo de controle sobre a legitimidade do processo de formação de preços, ainda que, diferentemente do que ocorre nos mercados de bolsa, a formação de preços propriamente dita não seja o seu alvo. Já o mercado de balcão nãoorganizado não é administrado por nenhuma instituição.” (YAZBEK, 2009, p. 144).

A Cetip - Câmara de Custódia e Liquidação e a SOMA - Sociedade Operadora do Mercado de Ativos são exemplos de mercado de balcão organizado.

A Cetip foi criada em 1984 pelo Conselho Monetário Nacional (CMN) e passou a operar em 1986. À época, o mercado financeiro carecia de um sistema eletrônico de liquidação financeira. Desde 2009, a Cetip é uma empresa de capital aberto e, atualmente, atua como entidade de balcão organizado e como câmara de custódia e liquidação de títulos e valores mobiliários, por autorização da CVM e do Banco Central.

A SOMA, por sua vez, foi criada em 1996, por iniciativa da Bolsa de Valores do Rio de Janeiro e Paraná, sendo o primeiro mercado de balcão organizado destinado à negociação de ações criado no Brasil.

É a Cetip, atualmente, que responde pela maior parte da negociação e liquidação dos títulos de emissão privada, inclusive CCBs, assim como pela liquidação das operações realizadas nas Bolsas Valores e de Mercadorias, englobando os mais diversos ativos. 
Embora muito se fale sobre oferta pública de CCB, esse título vem sendo negociado essencialmente de forma privada. Não há na CVM registros de oferta pública de CCBs ou mesmo de oferta pública com esforços restritos.

Já o volume em estoque de CCB na Cetip cresceu 19,7\% em 2011, em comparação com o ano anterior, e em julho de 2012 alcançou a marca de $\mathrm{R} \$ 26,07$ bilhões, o que representa um crescimento de $30,22 \%$ em comparação ao mesmo período de 2011 . $^{31}$

Dessa forma, em que pese a importância das discussões em torno da oferta pública de CCBs no campo teórico, sob uma perspectiva prática a oferta privada de CCBs possui uma maior relevância.

31 Fonte: Cetip. Disponível em: http://www.cetip.com.br/Noticias?NoticiaID=fab2e4b8-3f22-4225-a75db912750d1190. Acesso em: 10 de setembro de 2012. 


\section{NATUREZA JURÍDICA DA CCB}

Como já exposto no Capítulo 2 da segunda parte deste trabalho, a CCB é um título de crédito representativo de uma promessa de pagamento, passível de ser emitido tanto por pessoas físicas quanto jurídicas em favor de instituições financeiras, no âmbito de operações de crédito. A CCB constitui, dessa forma, um instrumento típico do mercado bancário, que inclusive foi criado pelo governo federal em resposta às demandas das instituições financeiras brasileiras por mecanismos mais ágeis e eficientes de cobrança de crédito.

Há quem entenda, porém, que a CCB, além de ser um título de crédito, deve ser considerada um valor mobiliário quando ofertada publicamente, vis-à-vis o previsto no inciso IX do artigo $2^{\circ}$ da Lei $n^{\circ} 6.385 / 76$.

Referido dispositivo prevê que "são valores mobiliários, sujeitos ao regime desta Lei, quando ofertados publicamente, quaisquer outros títulos ou contratos de investimento coletivo, que gerem direito de participação, de parceria ou de remuneração, inclusive resultante de prestação de serviços, cujos rendimentos advêm do esforço do empreendedor ou de terceiros". Conforme mencionado no Capítulo 3 da segunda parte do presente trabalho, esse conceito, adotado pelo direito brasileiro em 1998, é um conceito nitidamente instrumental e se assemelha ao conceito adotado pelo direito norte-americano.

Diante da expressão "quando ofertados publicamente", pode-se concluir que um mesmo título, dependendo de sua forma de negociação, pode ou não ser considerado um valor mobiliário. Conforme explica Luciana Pires Dias (2005, p. 35) em sua dissertação sobre Regulação e Autorregulação no Mercado de Valores Mobiliários:

Essa característica está relacionada à necessidade de regulação dos títulos ofertados publicamente e, portanto, torna o conceito instrumental, à semelhança do direito comunitário europeu. Assim como ocorre naquele sistema legal, o legislador brasileiro de 2001, ao conceituar valor mobiliário, teve como um dos objetivos delimitar a quem se aplicam determinadas regras. 
Portanto, é indiscutível que, se não for ofertada publicamente, uma CCB não pode ser considerada um valor mobiliário. Resta, portanto, a seguinte questão: quando ofertada publicamente, a CCB seria um valor mobiliário?

De acordo com o entendimento da CVM, as CCBs ofertadas publicamente devem ser consideradas valores mobiliários caso a instituição financeira em favor da qual elas forem emitidas exclua sua responsabilidade nos títulos.

Esse entendimento foi manifestado pela CVM no julgamento do Processo CVM n ${ }^{\circ}$ RJ2007-11593, que tratou do pedido de dispensa de registro de oferta pública de CCB de emissão da Brascor Investimentos Imobiliários Ltda., realizado pelo Itaú BBA S.A. O voto foi proferido, no final de janeiro de 2008, pelo então diretor da CVM, Marcos Barbosa Pinto, e acompanhado, na íntegra, pelos demais membros do Colegiado.

O relator do processo expôs da seguinte forma sua análise a respeito do enquadramento da CCB no conceito de valor mobiliário:

3.4 Na minha opinião, as CCBs satisfazem claramente os cinco primeiros requisitos que enumerei no item 2.11 acima, pelas seguintes razões:

i. ao adquirir uma CCB, o poupador está fazendo um investimento em renda fixa, o que satisfaz o requisito delineado no item 2.11(i) acima;

ii. o art. 26, caput, da Lei $\mathrm{n}^{\circ} 10.931 / 04$ deixa claro que as CCBs são títulos de crédito, atendendo assim o requisito descrito no item 2.11(ii) acima; a este propósito, vale destacar que embora o conceito de "valor mobiliário" não se confunda com o conceito de "título de crédito", sempre se admitiu que alguns títulos de crédito podem ser valores mobiliários, como é o caso das notas promissórias;

iii. a partir de uma mesma operação de crédito, e ressalvado o disposto no art. $28, \S 2^{\circ}$, II, da Lei $\mathrm{n}^{\circ} 10.931 / 04$, diversas CCBs com as mesmas características podem ser emitidas e transferidas a pessoas distintas, o que caracteriza o potencial coletivo do investimento nesses títulos e atende o requisito descrito no item 2.11(iii) acima;

iv. as CCBs pagam juros aos seus titulares e estes juros constituem, obviamente, uma remuneração, o que satisfaz o requisito descrito no item 2.11(iv) acima; a propósito, vale lembrar que, segundo nossos precedentes, a palavra "remuneração" empregada no inciso IX deve ser entendida em sentido lato, de forma a cobrir "qualquer investimento que o público faça na expectativa de obter algum rendimento"; e

v. a remuneração paga pelas $\mathrm{CCBs}$ tem origem nos esforços do empreendedor e não do investidor, já que este aguarda passivamente o pagamento dos juros incidentes sobre o crédito; também está satisfeito, portanto, o item 2.11(v) acima. 
Marcos Barbosa Pinto ressalta também em seu voto as exceções previstas no $§ 1^{\circ}$ do artigo $2^{\circ}$, segundo o qual não são valores mobiliários nem os títulos da dívida pública nem os títulos de responsabilidade das instituições financeiras. Daí decorre o requisito de não permanência da instituição financeira como responsável pelo adimplemento do título para a caracterização da CCB como valor mobiliário.

A caracterização da CCB como valor mobiliário permite que a CVM possa regular e fiscalizar as ofertas públicas de CCBs, uma vez que o conceito de valor mobiliário no direito positivo brasileiro delimita o campo de atuação da CVM, possuindo esse conceito um caráter nitidamente instrumental.

Em sua decisão, o Colegiado da CVM recomendou, ainda, que a Superintendência de Desenvolvimento do Mercado da CVM iniciasse a preparação de uma instrução normativa específica para regular o registro das emissões e dos emissores de CCBs. E assim foi feito. Em 16 de janeiro de 2009, foi editada a Instrução CVM nº 476, que dispõe sobre as ofertas públicas de valores mobiliários distribuídas com esforços restritos e a negociação nos mercados regulamentados.

Nos termos dessa Instrução, as ofertas públicas de CCBs que não sejam de responsabilidade de instituição financeira, distribuídas com esforços restritos, estão automaticamente dispensadas do registro de distribuição de que trata o caput do artigo 19 da Lei $n^{\circ} 6.385 / 76^{32}$. Essa Instrução estabelece também os elementos essenciais para a caracterização de uma oferta pública "com esforços restritos" (por exemplo, tais ofertas deverão ser destinadas exclusivamente a investidores qualificados). Portanto, a contrario sensu, as ofertas públicas de CCBs, que não se enquadrarem na Instrução CVM nº 476, devem ser levadas a registro na CVM.

A divulgação do entendimento do Colegiado da CVM, seguida da edição da Instrução CVM no 476, gerou grande polêmica no mercado e dividiu a doutrina pátria. Enquanto há doutrinadores que compartilham desse entendimento, outros consideram que as características de uma CCB não se coadunam, sob nenhuma circunstância, com o

32 Art. 19. Nenhuma emissão pública de valores mobiliários será distribuída no mercado sem prévio registro na Comissão. 
conceito de valor mobiliário e, portanto, não tem a CVM legitimidade para regulamentar e fiscalizar a circulação desses títulos.

Em artigo publicado logo após a divulgação do voto do Colegiado da CVM, o jurista Nelson Eizirik (2008) conclui que “A CCB manifestamente não atende aos requisitos necessários para a caracterização da figura do 'contrato de investimento', previsto no artigo $2^{\circ}$, inciso IX, da Lei $\mathrm{n}^{\circ}$ 6.385, de 1976”, justificando seu entendimento da seguinte forma:

Primeiramente, a criação da CCB não pressupõe a existência de um "empreendimento" por parte do devedor, uma vez que ela pode ser emitida para representar qualquer espécie de crédito detido pela instituição financeira, independente de sua origem. (...) Em segundo lugar, a expectativa do recebimento de "lucros" por parte do titular da CCB, inerente a qualquer investimento financeiro, não decorre diretamente dos resultados gerados pelo empreendimento gerido pelo devedor, mas tão somente da taxa de juros cobrada pela concessão do empréstimo.

Já Ary Oswaldo Mattos Filho (2008) possui entendimento diametralmente oposto. Para esse jurista, "o bom direito se encontra ao lado da autarquia", uma vez que:

1) as cédulas de crédito bancário são emitidas por empresas não-financeiras, portanto encontram-se fora do campo de competência do Banco Central; 2) a competência atribuída por lei à CVM refere-se aos contratos de investimento, e os adquirentes desses valores mobiliários fazem suas aplicações na expectativa de receber um rendimento, no caso, preestabelecido; 3) tais investimentos são colocados no mercado por intermédio do sistema de distribuição do mercado de valores mobiliários. O rendimento contratado é produzido pelo trabalho de terceiros e gera um direito de participação no empreendimento comum.

Em que pese o entendimento da CVM e de Ary Oswaldo Mattos Filho, pode-se concluir que não estão presentes na $\mathrm{CCB}$ todos os requisitos necessários para sua caracterização como valor mobiliário. Uma vez que a CCB não consta expressamente da relação prevista no artigo $2^{\circ}$ da Lei $n^{\circ} 6.385 / 76$, tal caracterização apenas seria viável se a CCB se enquadrasse no inciso IX desse mesmo artigo, o que, no entanto, não é o caso. Como visto, esse dispositivo traz três requisitos, os quais precisam ser cumulativamente atendidos:

(i) ser um título ou contrato de investimento coletivo ofertado publicamente;

(ii) gerar direito de participação, de parceria ou de remuneração, inclusive resultante de prestação de serviços; e 
(iii) ter seus rendimentos advindos do esforço do empreendedor ou de terceiros.

É certo que a CCB é um título de crédito que pode ser objeto de uma oferta pública e que gera um direito de remuneração aos seus adquirentes, atendendo aos dois primeiros requisitos do inciso IX do artigo $2^{\circ}$ da Lei $n^{\circ}$ 6.385/76. Todavia, essa remuneração não advém dos esforços do empreendedor ou de terceiros, decorre simplesmente da taxa de juros pactuada, como bem aponta o ilustre jurista Nelson Eizirik. Ora, nem sempre se contrai um empréstimo junto a instituições financeiras para fins de um empreendimento. Há razões diversas que levam as pessoas a obter um empréstimo.

Ademais, ainda que o empréstimo seja feito para viabilizar um determinado empreendimento, a instituição financeira que concede o crédito não tem qualquer pretensão de participar desse empreendimento. Certamente a instituição financeira não espera receber mais ou menos de acordo com o sucesso ou insucesso do empreendimento. Ao contrário, há uma remuneração certa, estabelecida no momento da emissão da $\mathrm{CCB}$, na forma de uma taxa de juros. O único risco assumido pela instituição credora é o risco de crédito do emissor da CCB. A CCB é somente um instrumento hábil à concessão de crédito, propiciando aos bancos uma maior segurança para a recuperação de crédito.

A não caracterização da CCB como valor mobiliário fica, ainda, mais evidente quando são analisadas as características da CCB vis-à-vis o conceito de contrato de investimento coletivo (investment contract) do direito norte-americano, no qual se inspirou o legislador brasileiro ao acrescentar ao rol do artigo $2^{\circ}$ da Lei ${ }^{\circ} 6.385 / 76$ o inciso IX. O conceito de investment contract, o qual foi examinado no Capítulo 3 da primeira parte deste trabalho, foi adotado pelo direito norte-americano em 1933, mediante a edição do Securities Act, e seus critérios foram definidos na década de 40 a partir do emblemático caso S.E.C. v. W.J. Howey Company. A definição de investment contract engloba os seguintes requisitos:

(i) investimento feito em dinheiro;

(ii) o objeto do investimento deve ser um empreendimento em comum; e

(iii) os rendimentos devem advir exclusivamente dos esforços do empreendedor ou de um terceiro. 
Desses três requisitos, a CCB, em regra, enquadra-se apenas no primeiro. É claro que em algumas situações é possível que o objetivo da obtenção de um empréstimo, mediante a emissão de CCB, seja viabilizar um empreendimento a ser desenvolvido pelo devedor, por exemplo, uma nova empresa que esse pretenda constituir ou uma plantação ou rebanho que deseje criar, porém, essa não é necessariamente a regra. E, conforme foi mencionado acima, ainda que o objeto do investimento seja um empreendimento, os rendimentos não advirão dos esforços do empreendedor ou de um terceiro, mas sim da taxa de juros cobrada.

Como visto no Capítulo 4 da primeira parte deste trabalho, assim como há títulos de crédito que podem se tornar valores mobiliários, alguns títulos de créditos, em razão de suas características, não são aptos a se tornarem valores mobiliários, e esse é o caso da CCB. 


\section{PROTEÇÃO DOS INVESTIDORES DE CCB}

\subsection{OS RISCOS INERENTES À CCB}

No financiamento bancário tradicional, a instituição que empresta os recursos tenta minimizar o risco de crédito fundamentalmente mediante dois mecanismos: inicialmente, pela análise de crédito, verificando, inclusive, a necessidade de exigir garantias, e, posteriormente, pelo monitoramento do devedor. Ademais, via de regra, a instituição absorve o risco de crédito, sustentando o ativo em seu balanço e alocando capital próprio para fazer face a ele.

Todavia, a capacidade das instituições financeiras de concederem empréstimos depende de seu enquadramento em certos limites impostos pelo Banco Central do Brasil. Em razão de tais limites, as instituições muitas vezes buscam, na medida do possível, distribuir o risco do empréstimo entre diversos investidores. Existem mecanismos diversos para essa distribuição de riscos, sendo um deles a colocação de CCBs no mercado.

Dessa forma, a instituição originadora do crédito pode transferir o risco de inadimplemento, mesmo para pessoas que não são parte do sistema financeiro, passando os investidores a serem os efetivos credores. Diante disso, é preciso regras disciplinando a negociação de CCBs, e estabelecendo mecanismos que garantam a proteção daqueles que investem em tais títulos.

O caso dos fundos do Banco Santos ilustra bem o risco a que os investidores estão sujeitos quando não há uma regulamentação e fiscalização adequada. Grande parte das CCBs originadas de financiamentos concedidos pelo Banco Santos era transferida para fundos de investimento administrados pelo próprio Banco Santos ou empresas de seu conglomerado. O Banco Santos administrava 82 fundos de investimento que, no total, possuíam um patrimônio de R \$ 2,7 bilhões, e contavam com 2.917 investidores. Apenas 20 fundos possuíam gestores independentes. Os outros 62 fundos eram geridos pela Santos Asset Management, empresa do mesmo grupo econômico do Banco. 
Apesar de ser a gestora de mais de sessenta fundos de investimento, a Santos Asset Management não dispunha de analistas especializados em risco de crédito para avaliar os títulos adquiridos pelos fundos, nem adotava qualquer critério de seletividade para os papéis originados pelo Banco Santos. Toda análise de risco de crédito era feita pela área de crédito do Banco. A gestora sequer tinha acesso aos relatórios produzidos pelos analistas do Banco sobre os ativos que estava adquirindo. Além disso, a Santos Asset Management não possuía autonomia para aprovar ou não a compra de títulos privados de crédito originados pelo Banco Santos.

Uma parcela expressiva do patrimônio de tais fundos de investimento era composta por ativos originados pelo Banco Santos. Para se ter uma ideia, à época da intervenção do Banco Santos, 98,17\% da carteira do Santos Credit Yield Fundo do Investimento, o qual, entre os fundos administrados pelo Banco Santos, possuía o maior patrimônio líquido (R\$ $582.798 .738,48)$ e o segundo maior número de cotistas (733), era composta por ativos originados pelo próprio Banco. Grande parte desses ativos consistia em CCBs emitidas em favor do Banco Santos. 72,15\% da carteira do Santos Credit Yield eram compostos por CCBs. Em outros fundos, esse percentual chegava a ser maior. No caso do Santos Credit Master, por exemplo, as CCBs representavam 99,94\% do patrimônio desse fundo. Na data da intervenção, 78\% do total de CCBs emitidas em favor do Banco Santos encontravam-se na carteira dos fundos por ele administrados. Apenas $22 \%$ estavam na carteira própria do Banco. $^{33}$

A CVM iniciou em maio de 2004 uma investigação nos fundos de investimento administrados pelo Banco Santos e pela Santos Asset Management, com o objetivo de apurar se tais fundos estavam adequados à regulamentação então em vigor. A Comissão de Inquérito da CVM concluiu que os investimentos dos fundos eram orientados pelos interesses do Banco Santos. Concluiu, ainda, que a Santos Asset Management não utilizava quaisquer critérios técnicos de gestão para a escolha e a distribuição das CCBs entre as carteiras dos fundos. Diversas outras irregularidades foram também apuradas pela Comissão de Inquérito. Diante disso, foi instaurado o Processo Administrativo Sancionador $n^{\circ} 01 / 05$.

\footnotetext{
${ }^{33}$ Fonte: Processo Administrativo Sancionador CVM n ${ }^{\circ}$ 01/05.
} 
Em voto proferido em 26 de novembro de 2008, o relator do processo, diretor Sergio Weguelin, destacou:

A defesa dos interesses dos cotistas é o mais importante dever a ser observado pelos administradores de fundos de investimento. No presente caso, ele não foi simplesmente descumprido, episodicamente, o que já seria muito grave. Este dever foi reduzido a nada, de maneira sistemática e sem o menor constrangimento.

Diante da gravidade dos fatos, o Colegiado da CVM decidiu aplicar penalidades de inabilitação para o exercício da atividade de administrador de carteira, por um prazo de 20 anos, e multa ao Banco Santos, na qualidade de administrador dos fundos de investimento, a Santos Asset Management, na qualidade de gestora dos fundos, e a seus respectivos diretores.

Outro caso que mostra bem os riscos envolvidos em uma operação de CCBs é o caso do Banco Morada, que teve sua intervenção decretada pelo Banco Central do Brasil em abril de 2011 e entrou em processo de liquidação extrajudicial em outubro daquele mesmo ano. Embora fosse um banco pouco conhecido e de pequeno porte, sua liquidação gerou prejuízos assombrosos a grandes fundos de pensão, fundações e gestoras de recursos.

O esquema montado pelo Banco Morada funcionava da seguinte forma:

(i) o Banco cedia a três empresas de seu grupo - Allcred, Secred e Morada SPE operações de crédito consignado que havia originado e que tinham alto grau de inadimplência. Grande parte deles recebia a classificação "H”, a pior na escala do Banco Central, que obriga o banco a fazer uma provisão de perdas equivalentes a 100\% do valor dos empréstimos. Dessa forma, o Banco Morada conseguia "limpar" o seu balanço, mantendo o grau de inadimplência da carteira de crédito sob controle e reduzindo a necessidade de capital da instituição;

(ii) em contrapartida à cessão dos créditos, as três empresas - Allcred, Secred e Morada SPE - assumiam a obrigação de pagar uma determinada quantia ao Banco Morada, obrigação essa que era representada por CCBs por elas emitidas em favor do Banco; 
(iii) tais CCBs eram vendidas pelo Banco Morada a investidores, sem coobrigação do Banco, com a promessa de uma alta remuneração.

Em razão dos investimentos feitos em tais CCBs, o fundo Petros, o fundo de pensão dos funcionários da Petrobras, segundo maior fundo de pensão do Brasil, com patrimônio de mais de $\mathrm{R} \$ 50$ bilhões, sofreu um prejuízo de pelo menos $\mathrm{R} \$ 72$ milhões.

Além do Petros, ao menos dez fundações e gestoras de recursos tinham CCBs emitidas pelas empresas do grupo Morada. Quando o Banco Morada sofreu intervenção, o estoque de CCBs somava cerca de R 132 milhões.

Outras fundações também investiram em CCBs de tais empresas. O instituto Metrus, dos funcionários do Metrô de São Paulo, aplicou cerca de R \$ 23 milhões no fim de 2008 em CCBs das empresas Allcred e Secred. As cédulas bancárias receberam da agência de classificação de risco LF Rating a nota "AA+", o que equivale a um risco de inadimplência muito baixo, segundo a escala de rating. ${ }^{34}$

\subsection{LIÇÕES DA CRISE DE 2008}

Guardadas as devidas diferenças, os casos relatados acima lembram em alguns aspectos as práticas que levaram o mundo a se deparar recentemente com uma das crises financeiras mais devastadoras da história, que ficou conhecida como a crise do subprime.

A recente crise financeira, que se iniciou em meados de 2007 nos Estados Unidos e tomou rapidamente proporções globais, mostrou ao mundo os efeitos danosos que o lançamento de títulos sem uma administração apropriada dos ativos subjacentes e sem uma minuciosa avaliação dos riscos envolvidos pode provocar.

\subsubsection{Causas da Crise}

Embora haja diferentes explicações para o surgimento da crise, pode-se dizer que a maioria gira em torno de dois fatores centrais: a busca contínua dos investidores por

\footnotetext{
${ }^{34}$ Fonte: Jornal Valor Econômico. Disponível em: http://www.valor.com.br/financas/2572910/petros-perdeur-70-mi-com-morada. Acesso em: 16 de março de 2012.
} 
maiores ganhos, o que os foi levando a investir cada vez mais em ativos de alto risco, e a procura dos bancos por mecanismos sofisticados que permitissem a transferência do risco de crédito para terceiros de modo a obter liquidez para novas operações, seguindo o modelo "originate and distribute".

A essência do modelo de "originate and distribute" é possibilitar ao banco originador a emprestar muito mais do que seus ativos normalmente permitiria. Isso significa que a operação do banco originador depende de sua capacidade de distribuir, que assegura a constante entrada de novo capital.

Esses dois fatores levaram à criação do sistema das hipotecas subprimes, empréstimos hipotecários de alto risco concedidos a famílias com baixo poder aquisitivo, ou seja, para os clientes apelidados de "ninja", do acrônimo sem renda, sem emprego fixo e sem ativos para dar como garantia. Mesmo em uma economia desenvolvida como a norteamericana, essas pessoas formam um enorme contingente da população e, portanto, representam um mercado promissor para financiamentos imobiliários. Alem disso, não apenas representam uma grande reserva de possíveis tomadores de empréstimos, como também possibilitam uma margem maior de lucro, já que, quanto maior o risco, maiores as taxas cobradas para a concessão do empréstimo.

Em um passo seguinte, foram desenvolvidos derivativos negociáveis no mercado financeiro, instrumentos sofisticados para securitizar os créditos hipotecários, transferindo o risco para contrapartes e obtendo liquidez para novas operações. A securitização, em linhas gerais, consiste em uma operação por meio da qual o originador segrega de seu patrimônio determinado ativo em um veículo de propósito específico - que pode ser uma sociedade, um fundo, um trust - mediante cessão de crédito ou contrato. "A partir do lastro representado pelo ativo cedido, esse veículo emite títulos a serem adquiridos por investidores, que, assim, antecipam uma receita que só no futuro seria realizada pelo originador" (CAMINHA, 2004, p. 45). Dessa forma, com a securitização, o risco do empréstimo é distribuído entre diversos investidores que compram títulos representativos de uma dívida, e são lastreados por um ativo a ela correspondente.

Títulos lastreados em créditos hipotecários passaram, então, a ser negociados pelos bancos. E, embora os ativos subjacentes fossem os créditos imobiliários garantidos pelas 
hipotecas, ativos historicamente considerados de longo prazo, a abundância de liquidez no mercado verificada até 2007 levou muitos investidores a ignorarem a natureza dos ativos subjacentes.

Além disso, o risco envolvido era avaliado com base nas análises das agências de classificação de risco (rating agencies). Todavia, essas agências eram envolvidas apenas no momento da oferta inicial dos títulos e não monitoravam as mudanças subsequentes na avaliação dos ativos subjacentes.

Nas palavras de Haroldo Malheiros Duclerc Verçosa (2008, p. 12):

Dentro de todo este quadro, anota-se que houve a perda da visão de que os ativos originalmente subjacentes correspondiam a operações de longo prazo; que as agências de risco estavam envolvidas apenas nas operações ao tempo do seu nascimento; que, em meio a uma grande onda de demanda, os bancos reduziram sua exposição a riscos em níveis reduzidos, os quais destruíram o incentivo de monitorar apropriadamente os empréstimos concedidos; e, finalmente, que os bancos com dificuldade de continuarem atuando dentro do modelo "originate e distribute" logo encontraram problemas para manterem o constante fluxo de recursos, tendo isto acarretado a quebra da corrente financeira que os ligava. Esta última circunstância foi agravada pelo fato de que os bancos originais deixaram de fazer constar dos balanços as operações em causa.

Quando o Federal Reserve norte-americano, em 2005, aumentou a taxa de juros como medida de combate à alta da inflação, desregulou-se esse sistema: o preço dos imóveis caiu, inviabilizando o seu refinanciamento para os clientes "ninja", ao mesmo tempo em que os juros subiram. Muitas pessoas ficaram sem renda suficiente para quitar seus empréstimos ou pagar os juros devidos. Isso acarretou uma inadimplência em massa no momento em que os investidores, que haviam comprado títulos baseados nas hipotecas, perceberam que poderiam não receber o retorno que esperavam.

Quando essa percepção se espalhou, gerou uma enorme crise de confiança quanto a todos os produtos estruturados de crédito. A perda de confiança dos investidores levou rapidamente a uma crise de liquidez que atingiu todo o sistema e revelou suas debilidades e inconsistências.

Muitos instrumentos financeiros que permitiam a transferência de riscos de crédito, dando suporte ao modelo "originate and distribute", tiveram grande participação na crise. 
Um desses instrumentos é o Credit Default Swap (CDS), espécie de derivativo que permite a transferência do risco de crédito, nos lembrando mais uma vez as CCBs. Em linhas gerais, o Credit Default Swap funciona da seguinte forma: uma determinada pessoa que possui um crédito contra um devedor, e teme pela inadimplência deste, procura uma instituição financeira e contrata proteção quando um evento de inadimplência, assumindo, em contrapartida, a obrigação de transferir a tal instituição uma parte de sua margem. Com o passar dos anos foram acrescentados ao CDS diversos elementos, que o levaram a deixar de corresponder a uma simples operação bilateral, semelhante a um seguro de crédito, e o transformaram em um complexo derivativo. Foram criadas, por exemplo, a possibilidade de múltiplas entidades referenciadas, ou seja, um mesmo CDS poderia oferecer proteção a riscos variados, e a possibilidade de liquidação financeira, ao invés de entrega física da dívida, o que permitiu que mesmo aqueles que não possuíssem qualquer dívida a ser protegida adquirissem o CDS (chamado de CDS “naked"). Tais elementos não apenas tornaram os CDSs mais complexos como também levaram a um grande aumento do volume de negócios envolvendo CDS, que passou de US\$ 600 bilhões em 2001 a US\$ 62 trilhões em 2007.

Outro instrumento financeiro apontado como protagonista da crise, que, assim como o CDS, permite a transferência do risco de crédito, é o Collateralized Debt Obligation (CDO). O CDO funciona basicamente da seguinte forma: um banco, após realizar, por exemplo, um determinado financiamento imobiliário, cede os recebíveis decorrentes desse financiamento a uma sociedade de propósito específico (SPE) ou celebra com a SPE um CDS por meio do qual compra da SPE uma proteção contra o risco de crédito referente ao crédito imobiliário. No primeiro caso o CDO é conhecido como CDOfluxo de caixa e no segundo como CDO-sintético. A SPE então emite títulos lastreados em tais recebíveis. Esses títulos são divididos em diferentes níveis de senioridade, sendo que quanto mais sênior for menor o grau de risco e menor também o potencial de ganho.

A crise revelou o risco desses instrumentos e uma das muitas lições que deixou é que as inovações financeiras precisam ser analisadas com grande cautela. Conforme destaca Haroldo Malheiros Duclerc Verçosa (2008, p. 15), tais inovações possuem dois problemas principais: (i) o distanciamento do ativo subjacente quando derivativos criados em cascata são negociados sucessivamente por diversas instituições financeiras, o que leva ao desaparecimento da possibilidade de aferir a consistência do referido ativo e sua 
permanência ao longo do tempo; e (ii) a criação de inovações financeiras artificiais ou até mesmo fraudulentas que não preenchem uma finalidade econômica útil, servindo puramente como instrumento especulativo ou destinado a proporcionar ganhos indevidos em detrimento dos investidores.

\subsubsection{Reforma do Sistema Financeiro}

Os agentes do mercado, reguladores e regulados procuraram entender as causas da crise e aprender suas lições. Algo poderia ter sido feito para impedir ou, ao menos, mitigar a crise? Como evitar ou ao menos se preparar para novas crises? Uma das respostas encontradas para essas indagações foi a reforma regulatória (ou re-regulação).

Passou-se, inclusive, a buscar uma regulação global, além de reformas nas legislações locais.

No Reino Unido, por exemplo, foi promulgado em 2009 o Banking Act que dispõe sobre nacionalização de bancos, alterando a lei de insolvência e administração de bancos, e trazendo, ainda, diversas outras alterações à legislação bancária.

Já nos Estados Unidos, foi sancionado em julho de 2010 o Dodd-Frank Wall Street Reform and Consumer Protection Act, na tentativa de se evitar novas crises semelhantes à de 2008. O Dodd-Frank, considerada a legislação do sistema financeiro de maior relevância editada desde a década de 30, trouxe grandes mudanças à regulamentação do mercado financeiro e de capitais norte-americano. Tais mudanças abrangem, inclusive, as operações de securitização lastreadas em ativos (asset-baked securitization) e as agências de rating, consideradas dois dos principais agentes causadores da crise de 2008.

No tocante às operações de securitização, a nova lei criou regras de retenção de parte do risco de crédito. Como visto, o modelo, conhecido como "originate and distribute", foi, por muitos anos, largamente utilizado sem qualquer regulamentação. Isso acabou levando os originadores a não se preocuparem com uma análise de risco adequada para a concessão do crédito. Porém, com a edição do Dodd-Frank Act, passa a ser obrigatória a retenção de, no mínimo, $5 \%$ do risco de crédito pelos originadores ou pelas securitizadoras. Conforme observa Ruy Pereira Camilo Junior (2011, p. 85), em artigo 
sobre a reforma do sistema financeiro norte-americano, "a lei determina que o gerador do crédito mantenha algum nível de interesse econômico quando de sua securitização e transferência, pondo a 'pele em jogo' (skin in the game), objetivando-se com isso o alinhamento de interesse com os investidores que adquiram o crédito".

Além disso, o Dodd-Frank Act confere amplos poderes à SEC para exigir uma auditoria detalhada dos ativos securitizados, bem como dos ativos subjacentes. Também concede poderes para exigir que agências de rating descrevam em seus relatórios as declarações e garantias prestadas pelos originadores e pelas securitizadoras com relação aos ativos securitizados.

Com base no Dodd-Frank Act, em janeiro de 2011, a SEC adotou novas regras exigindo que emissores de valores mobiliários lastreados em ativos prestem determinadas declarações e garantias, bem como conduzam uma auditoria dos ativos subjacentes a esses valores mobiliários e forneçam informações sobre essa auditoria. A exigência referente à prestação de declarações e garantia também se aplica às agências de rating.

Em síntese, a crise acentuou a necessidade de economistas e operadores do direito pensarem e agirem em conjunto o tempo todo. Como bem observa Haroldo Verçosa (2008, p. 30), é “impossível a existência de qualquer mercado na ausência de um mínimo de segurança jurídica, destinada a garantir o cumprimento das obrigações nele assumidas".

Parece que algumas das lições deixadas pela crise podem ser aplicadas às negociações de CCBs. Dado que a CCB constitui uma promessa de pagamento daquele que contrata uma operação de crédito com uma instituição financeira, uma vez transferida essa cédula, o endossatário passa a figurar como credor na relação de crédito representada pela CCB. Essa transferência pode se dar com ou sem coobrigação da instituição financeira. Caso haja essa coobrigação, o adquirente da cédula pode demandar seu crédito tanto do emitente da cédula como da própria instituição financeira. No entanto, não havendo essa coobrigação, resta ao adquirente da cédula executar o emitente em caso de inadimplemento. Daí a importância de se estabelecer mecanismos de proteção daqueles que investem em CCBs, seja de forma direta ou através de fundos de investimento. 


\subsection{MECANISMOS DE PROTEÇÃO DOS INVESTIDORES}

Como visto, o conceito de valor mobiliário possui um caráter nitidamente instrumental, pois define o campo de atuação da CVM. Nesse contexto, a CVM entendeu em 2008 que a CCB, quando ofertada publicamente, é valor mobiliário, estando, assim, a oferta pública dessa cédula sujeita ao prévio registro na CVM. O registro visa a proteger os investidores, sendo um mecanismo para lhes assegurar o acesso a informações claras e precisas sobre os valores mobiliários ofertados.

Todavia, como pode ser visto no Capítulo 4 da segunda parte deste trabalho, a CCB não atende aos requisitos necessários para sua caracterização como valor mobiliário. Não deveria, assim, a CVM ter competência para exigir o registro de ofertas públicas de CCBs.

Além disso, ainda que a CCB pudesse ser considerada um valor mobiliário, não parece que a proteção outorgada nesse caso seria suficiente para proteger os investidores. Primeiro porque essa proteção existiria apenas no caso de oferta pública de CCB. Segundo porque o principal efeito da caracterização da CCB como valor mobiliário é apenas submeter esse título ao regime da plena disponibilização de informações (full disclosure). Como já visto no Capítulo 6 da primeira parte deste trabalho e conforme será observado melhor adiante, o sistema de full disclosure é insuficiente para a proteção daqueles que investem em CCBs. Portanto, ainda que a CVM supervisione a efetiva e pontual divulgação de informações relacionadas às $\mathrm{CCBs}$, o risco para os investidores continua existindo.

São necessárias regras específicas que estabeleçam procedimentos a serem observados tanto para a concessão do crédito que lastreia a CCB como para a negociação dessa cédula, que, via de regra, ocorre de forma privada. Os órgãos reguladores, inclusive a CVM, e autorreguladores já vêm publicando uma série de recomendações a serem adotadas com relação à CCB.

A Associação Nacional das Instituições do Mercado Aberto - Andima (atualmente, Associação Brasileira das Entidades dos Mercados Financeiro e de Capitais - Anbima, em razão da associação com a Anbid) publicou, em 24 de julho de 2008, o Parecer de Orientação $\mathrm{n}^{\mathrm{o}} 11 / 08$, o qual recomenda que as instituições associadas e aquelas que 
aderiram aos Códigos da Anbima observem determinadas regras e procedimentos ao realizar operações privadas de CCBs. Esse parecer é resultado de um extenso levantamento feito pela Anbima junto a seus associados sobre o mercado de CCB.

Os procedimentos e boas práticas recomendados pela Anbima dizem respeito à avaliação e aprovação de operações de crédito, registro das CCBs, perfil dos investidores e possíveis conflitos de interesse. Conflitos de interesse podem existir quando a instituição financeira presta serviços ou atua diretamente em operações de captação de recursos, por meio de oferta pública, para clientes para os quais tenha concedido ou pretenda conceder crédito por intermédio de CCBs.

Com base no Parecer de Orientação n 11/08, a Anbima, ainda, incluiu em seu Código de Regulação e Melhores Práticas para Fundos de Investimento um novo artigo que estabelece os procedimentos mínimos que os gestores devem adotar para as aquisições de títulos e valores mobiliários representativos de dívidas ou obrigações não soberanas (Crédito Privado) para os fundos que estão sob sua gestão. Tais procedimentos são os seguintes:

(i) somente adquirir Crédito Privado caso tenha sido garantido o acesso às informações necessárias à devida análise de crédito para compra e acompanhamento do ativo;

(ii) dispor em sua estrutura, ou contratar terceiros, equipe ou profissionais especializados nas análises jurídicas, de crédito, de compliance e de riscos de operações com Crédito Privado, que possibilitem a avaliação do negócio e o acompanhamento do título após sua aquisição;

(iii) exigir o acesso aos documentos integrantes da operação ou a ela acessórios e, nas operações com garantia real ou fidejussória, a descrição das condições aplicáveis ao seu acesso e execução;

(iv) monitorar o risco de crédito envolvido na operação, bem como a qualidade e capacidade de execução das garantias, enquanto o ativo permanecer na carteira do Fundo; 
(v) em operações envolvendo empresas controladoras, controladas, ligadas e/ou sob controle comum da Instituição Participante gestora e/ou administradora do Fundo, observar os mesmos critérios que utiliza em operações com terceiros, mantendo documentação de forma a comprovar a realização das operações em bases equitativas;

(vi) adquirir apenas Crédito Privado de emissores, pessoas jurídicas, e que tenham suas demonstrações financeiras auditadas por auditor independente; e

(vii) utilizar o rating e a respectiva súmula do ativo ou do emissor, fornecido por agência classificadora de risco, quando existir, apenas como informação adicional à avaliação do respectivo risco de crédito e dos demais riscos a que devem proceder, e não como condição suficiente para sua aquisição.

Ressalta-se que tais procedimentos não se aplicam (i) aos FIDCs e (ii) ao Crédito Privado que conte com (a) cobertura integral de seguro; (b) carta de fiança emitida por instituição financeira; ou (c) coobrigação integral por parte de instituição financeira ou seguradoras ou empresas que tenham suas demonstrações financeiras auditadas por auditor independente.

Já a CVM publicou em 2010 o Ofício-Circular/CVM/SIN/N 02/2010, que tem por objetivo orientar os administradores de fundos de investimento regulados pela Instrução CVM no 409/04 quanto aos procedimentos mínimos recomendáveis em operações com CCBs, diante dos riscos inerentes a esses ativos.

Nesse Ofício a Superintendência de Relações com Investidores Institucionais manifestou seu entendimento de que, em vista da obrigação de diligência estabelecida no inciso I do artigo 65-A da Instrução CVM n ${ }^{\circ}$ 409/04, devem ser adotadas práticas consistentes, objetivas e passíveis de verificação, que permitam a compreensão e precificação dos riscos associados aos ativos investidos. Tais práticas devem, ainda, garantir um padrão aceitável de controles internos e de gerenciamento dos riscos operacional, de mercado, de liquidez e de crédito associados à gestão de recursos de terceiros. 
Entre os procedimentos recomendados pela CVM, os quais em grande parte se assemelham aqueles estabelecidos pela Anbima, estão os seguintes:

(i) somente adquirir $\mathrm{CCB}$ caso tenha sido garantido o acesso às informações produzidas pela área de análise de crédito do credor original, bem como o fornecimento de outras informações julgadas necessárias sobre a operação representada na $\mathrm{CCB}$ e sobre o respectivo emissor;

(ii) avaliar a adequação da $\mathrm{CCB}$ à política de investimento do fundo e ao seu público alvo;

(iii) dispor em sua estrutura, ou contratar profissionais especializados nas análises jurídicas, de crédito, de compliance e de riscos de operações com CCBs, que possibilitem a avaliação do devedor e o acompanhamento do título após sua aquisição, podendo também utilizar o rating do ativo ou do emissor, fornecido por agência classificadora de risco, quando existir, apenas como informação adicional à avaliação do respectivo risco de crédito e dos demais riscos a que devem proceder, e não como condição suficiente para sua aquisição;

(iv) exigir o acesso aos documentos integrantes da CCB ou a ela acessórios e, nas operações com garantia real ou fidejussória, a descrição das condições aplicáveis ao seu acesso e execução, bem como a formalização de eventuais restrições ao exercício de direitos;

(v) reunir, em operações envolvendo terceiros ligados, documentação adicional de forma a comprovar a realização da operação em bases equitativas;

(vi) renovar periodicamente, enquanto o ativo permanecer na carteira do fundo, as avaliações do risco de crédito envolvido na operação, bem como da qualidade e capacidade de execução das garantias;

(vii) verificar se a cédula foi endossada para a CETIP na forma prevista pelo artigo 35, inciso VII, do "Regulamento de Acesso de Participante, de Admissão de Ativo, de Negociação, de Registro de Operação, de Custódia Eletrônica e de Liquidação", antes de 
adquirir uma CCB no sistema da CETIP S.A. - Balcão Organizado de Ativos e Derivativos; e

(viii) adquirir apenas CCBs de empresas devedoras que tiverem suas demonstrações financeiras auditadas por auditor independente.

São, sem dúvida, louváveis as iniciativas tanto da Anbima quanto da CVM em desenvolver mecanismos de proteção aos riscos inerentes às CCBs e representam um grande passo para uma proteção mais eficaz dos investidores. Porém, tais mecanismos são suficientes?

Analisando as características das CCBs, os escândalos já descobertos envolvendo esses títulos, como o do Banco Santos e do Banco Morada, e, ainda, os bastidores da recente crise financeira internacional, fica evidente que não. Primeiro porque tais mecanismos apenas se aplicam aos fundos de investimento, não abrangendo, dessa forma, todo o universo de investidores. Em segundo lugar, grande parte das orientações e regras acima expostas pressupõe que os gestores terão condições de realizar uma adequada análise de risco de crédito. No entanto, se no momento da concessão do crédito, os riscos forem indevidamente apurados pelas instituições financeiras, sem que sejam reunidas por essas as informações necessárias para tal apuração, os investidores e mesmo os gestores conseguirão fazer uma análise adequada? Luiz Alfredo Paulin (2008, p. 51), em seu artigo a respeito da transferência de cédulas de crédito bancário, ajuda a responder essa questão:

Mesmo em face de dados precisos e pormenorizados a respeito de um crédito bancário, faltará ao investidor comum condições para processar estes dados, de forma conveniente. Até porque a capacidade de mensurar riscos de crédito não é tarefa acessível ao leigo. Por esta razão, insiste-se, o fornecimento de informações está longe de ser suficiente.

Faltam, principalmente, regras que incentivem as próprias instituições financeiras a fazerem uma análise de risco com a perícia necessária no momento da concessão do crédito.

É claro que as instituições financeiras já estão obrigadas, por normas emanadas pelo Conselho Monetário Nacional e pelo Banco Central do Brasil, a realizarem uma análise de crédito antes de concederem recursos a um cliente, seja mediante a emissão de 
uma CCB ou através de outro instrumento. Nos termos da Resolução ${ }^{\circ} 1.559$, editada pelo Conselho Monetário Nacional em 22 de dezembro de 1988, é, por exemplo, vedado às instituições financeiras realizar operações que não atendam aos princípios de seletividade, garantia, liquidez e diversificação de riscos. Aqui vale citar novamente as lições de Luiz Alfredo Paulin (2008, p. 36-37):

\begin{abstract}
A concessão de crédito, por parte de instituição financeira, não é atividade exercida de forma anárquica. Para que um crédito seja concedido é obrigação da instituição financeira observar certas regras. Note-se, por oportuno, que a conformação com as regras não tem conexão com o tipo de instrumento através do qual o crédito será deferido. Ou seja, independentemente da espécie de instrumento a serem utilizados, na concessão de crédito a instituição financeira está constrangida a tomar certos cuidados, (...) Em sendo assim, mostra-se incontroverso que, antes de receber uma cédula de crédito bancário é dever de a instituição financeira atentar a certos cuidados. Estes cuidados consistem na averiguação da capacidade do emitente em satisfazer as obrigações que pretende assumir. É também dever da instituição financeira, sendo o caso, requerer que sejam constituídas garantidas.
\end{abstract}

Em caso de infração de seus deveres, as instituições financeiras estarão sujeitas, no âmbito administrativo, a determinadas sanções que podem ser impostas pelo Banco Central do Brasil, as quais variam desde uma mera advertência à cassação da autorização para funcionamento. Neste caso haveria, portanto, uma ação punitiva do Banco Central do Brasil, o que, sem dúvida, é necessário para assegurar a estabilidade e solidez do sistema financeiro nacional. Podem, ainda, as instituições financeiras estarem sujeitas a uma eventual responsabilidade civil dependendo do prejuízo causado e da comprovação de que atuaram com dolo ou culpa. Todavia, é essencial haver também medidas preventivas, que impeçam ou, ao menos, veementemente desincentivem as instituições financeiras de se esquivarem de uma análise de risco adequada, minuciosa, no momento da concessão do crédito através da emissão de uma $\mathrm{CCB}$, principalmente diante da possibilidade de transferência da CCB sem coobrigação.

Se for possível transferir, logo após a concessão do crédito, todo o risco atrelado a tal crédito, as instituições financeiras, especialmente aquelas que não prezam tanto por sua reputação, não deixariam de ter um incentivo para gastar recursos em análises de risco minuciosas? Ainda que haja sanções previstas no regulamento pátrio, é crucial existirem também medidas preventivas. Ora, no momento da ação punitiva, investidores já terão sido prejudicados. Ademais, é extremamente complexo julgar, a posteriori, se uma determinada 
análise de crédito foi devidamente conduzida, somando-se a isso, ainda, o fato de haver, no mercado, diferentes padrões de análise de risco de crédito, havendo instituições que adotam parâmetros muito menos rígidos que outras.

Nos Estados Unidos, as atenções já se voltaram para esse problema. Como visto, dentre as disposições do Dodd-Frank Act, há regras que atingem exatamente a questão da transferência do risco de crédito, apontada como uma das causas da crise. A nova lei determina a retenção de, no mínimo, $5 \%$ do risco de crédito pelos originadores ou pelas securitizadoras. Já no Brasil ainda $100 \%$ dos créditos podem ser passados adiante, carregando riscos indevidamente apurados.

\subsection{A FIGURA DO AGENTE DE GARANTIA}

Diante das características da CCB, é necessário um monitoramento constante do cumprimento das obrigações representadas por essa cédula, o gerenciamento de eventuais garantias atreladas e, sendo o caso, a execução de tais garantias. Para exercer essas atividades, é comum nas emissões de CCBs que haja um "agente de garantia". Geralmente esse "agente" é a própria instituição financeira em favor da qual foi originalmente emitida a $\mathrm{CCB}$, que fica responsável pelo recebimento dos valores a serem pagos por força das CCBs, pelo gerenciamento das garantias, por eventual cobrança das CCBs, entre outras atribuições.

Antes mesmo da criação da $\mathrm{CCB}$, o mercado financeiro nacional já utilizava recorrentemente a figura do "agente de garantia" para viabilizar operações de crédito sindicalizado. Todavia, essa figura não é expressamente disciplinada pela legislação brasileira.

O reconhecimento pelo ordenamento jurídico brasileiro da figura do agente de garantia, como ocorre com o agente fiduciário dos debenturistas, proporcionaria uma maior proteção aos adquirentes de CCBs. 


\subsubsection{O agente fiduciário no Brasil e em outras jurisdições}

A figura do agente fiduciário dos debenturistas, prevista no artigo 68 da Lei $n^{\circ}$ 6.404/76, nasceu da necessidade de se proteger os interesses dos debenturistas, dada a impossibilidade prática de os próprios debenturistas defendê-los, em termos permanentes.

Conforme destaca Modesto Carvalhosa (2009, p. 780):

A instituição do agente fiduciário parte dos corretos pressupostos de que o interesse dos debenturistas é comum e que seria impossível, na prática, defendê-lo em termos permanentes pelos próprios debenturistas. Daí a instituição da figura de um profissional ou de instituição especializada capaz de proporcionar essa proteção.

Nas palavras de José Waldecy Lucena (2009, p. 674):

Tão logo surgidas as obrigações (debêntures), sentiu-se que a homogeneidade dos direitos conferidos a seus titulares indicava a existência de interesses comuns, formativos de uma comunhão, os quais seriam mais bem fiscalizados e exercidos se em conjunto do que individualmente.

Trajano de Miranda Valverde (1953, p. 197) também ressalta a necessidade de se organizar e defender os interesses dos debenturistas:

\footnotetext{
Verificou-se cedo a necessidade de se organizar essa comunhão de interesses, a bem da defesa dos portadores dos títulos e da própria sociedade emissora, para que o capricho, o egoísmo, a insensatez de um ou de alguns debenturistas, ou ainda a encoberta concorrência desleal, não provocasse, em momento de crise econômica generalizada, ou particular a um determinado ramo de indústria ou de comércio, ou oriunda de circunstâncias peculiares à sociedade devedora, sérios e irremediáveis prejuízos.
}

Em outras jurisdições também há agentes com papéis bem semelhantes. Nos Estados Unidos a figura do "trustee" tornou-se uma figura de larga tradição no mercado financeiro desde o fim do século XIX. Em 1939, foi regulamentada pelo Trust Indenture Act, que tem por finalidade a proteção dos investidores de notas, debêntures, outras espécies de títulos de dívida, entre outros valores mobiliários. 
Já a lei francesa confere personalidade jurídica à massa dos obrigacionistas. O artigo L. 228-46 do Código de Comércio francês prevê que os portadores de obrigações de uma mesma emissão são agrupados de pleno direito para a defesa de seus interesses comuns em uma massa que goza de personalidade civil. ${ }^{35} \mathrm{E}$, nos termos do artigo L. 22847, "a massa é representada por um ou vários mandatários eleitos pela assembleia geral de obrigacionistas". ${ }^{36}$ Como define o jurista francês Daniel Ohl (2003, p. 129):

A massa é uma pessoa jurídica sem patrimônio. Os obrigacionistas não lhe fazem aporte de seus direitos. (...) Ela se concebe simplesmente como uma ferramenta jurídica posta pelo legislador à disposição dos obrigacionistas para lhes permitir exercer seus direitos e de defender seus interesses comuns.

$\mathrm{Na}$ Itália, nomeia-se um representante comum dos obrigacionistas. Cabe a nomeação à assembleia de obrigacionistas. Se esta não o fizer, a nomeação é feita pelo Tribunal, a requerimento de um ou mais obrigacionistas ou dos administradores da sociedade emissora (Código Civil, artigos 2415 e 2417). ${ }^{37}$

Em Portugal, também se adota um representante comum dos obrigacionistas, por este designado e destituído em assembleia (Código das Sociedades Comerciais, artigo 355 e ss)..$^{38}$

35 Article L228-46 Les porteurs d'obligations d'une même émission sont groupés de plein droit pour la défense de leurs intérêts communs, en une masse qui jouit de la personnalité civile. Toutefois, en cas d'émissions successives d'obligations, la société peut, lorsqu'une clause de chaque contrat d'émission le prévoit, grouper en une masse unique les porteurs d'obligations ayant des droits identiques.

36 Article L228-47 La masse est représentée par un ou plusieurs mandataires élus par l'assemblée générale des obligataires. Leur nombre ne peut en aucun cas excéder trois. Les représentants peuvent être désignés dans le contrat d'émission.

37 Art. 2415 Assemblea degli obbligazionisti. L'assem sulla nomina e sulla revoca del rappresentante comune(...). Art. 2417 Rappresentante comune. Il rappresentante comune può essere scelto al di fuori degli obbligazionisti. Se non è nominato dall'assemblea a norma dell'art. 2415, è nominato con decreto dal presidente del tribunale su domanda di uno o più obbligazionisti o degli amministratori della società (att. 104). Non possono essere nominati rappresentanti comuni degli obbligazionisti e, se nominati, decadono dall'ufficio, gli amministratori, $i$ sindaci, i dipendenti della società debitrice e coloro che si trovano nelle condizioni indicate nell'art. 2399. Il rappresentante comune dura in carica per un periodo non superiore ad un triennio e può essere rieletto. L'assemblea degli obbligazionisti ne fissa il compenso. Entro quindici giorni dalla notizia della sua nomina il rappresentante comune deve richiederne l'iscrizione nel registro delle imprese (2634; att. 210).

38 Artigo 355. (Assembleia de obrigacionistas). (...) 4. A assembleia dos obrigacionistas delibera sobre todos os assuntos que por lei lhe são atribuídos ou que sejam de interesse comum dos obrigacionistas e nomeadamente sobre: a) Nomeação, remuneração e destituição do representante comum dos obrigacionistas; (...). 
Já na Argentina, a sociedade emissora deve celebrar um contrato de fideicomisso com um banco, ao qual compete a representação dos debenturistas (Lei das Sociedades Comerciais - Lei 18.550/1972, artigo 338).

No Brasil, embora diplomas legais anteriores já tratassem da comunhão de interesses entre os debenturistas, o agente fiduciário dos debenturistas foi criado em 1976 pela Lei das Sociedades por Ações. Conforme revela a Exposição de Motivos da Lei das Sociedades por Ações, o legislador percebeu a necessidade de se criar e regular a função do agente fiduciário para assegurar maior proteção aos investidores do mercado:

A experiência dos países que, na tradição do direito continental europeu, desconhecem essa função, revela a inadequação da solução adotada pelo nosso Decreto-lei $\mathrm{n}^{\circ}$ 781, de 12.10.1938, da reunião eventual de assembléia de debenturistas, o que em geral somente ocorre quando a companhia emissora tem interesse em modificar as condições das debêntures em circulação ou já se ache inadimplente. A proteção eficiente dos direitos e interesses dos debenturistas requer fiscalização permanente e atenta por pessoa habilitada, com as responsabilidades de administrador de bens de terceiros, independente da companhia devedora e dos demais interessados na distribuição das debêntures, e que não tenha interesses conflitantes com os dos debenturistas, cujos direitos e interesses deve proteger.

A nomeação do agente fiduciário é obrigatória nas emissões distribuídas ou admitidas à negociação no mercado, sendo facultativa nas emissões privadas.

O agente fiduciário é responsável pela proteção dos direitos e interesses dos debenturistas, por informá-los dos fatos relevantes ocorridos durante o ano relativos à execução das obrigações assumidas pela companhia e aos bens garantidores das debêntures, e notificá-los de qualquer inadimplemento, pela companhia, de obrigações assumidas na escritura da emissão.

O agente fiduciário pode, ainda, usar de qualquer ação para proteger direitos ou defender interesses dos debenturistas, sendo-lhe facultado tomar qualquer providência necessária para que os debenturistas realizem os seus créditos. O agente fiduciário possui poderes, inclusive, para, no caso de inadimplemento da companhia, declarar o vencimento antecipado das debêntures e cobrar seu principal e acessórios, executar as garantias reais, requerer a falência da companhia emissora, se não existirem garantias reais. 


\subsubsection{O agente de garantia de $\mathrm{CCB}$}

Assim como ocorre em uma emissão de debêntures, em uma emissão de CCBs há também uma comunhão de interesses, que carece igualmente de proteção. E essa proteção poderá ser assegurada de uma forma mais eficaz se houver um profissional ou uma instituição especializada capaz de defender os interesses dos titulares de CCBs, e com poderes legais para tanto, semelhantes aos poderes dos agentes fiduciários.

Ainda que os titulares de CCBs decidam nomear um representante legal para representá-los, não havendo uma previsão legal que outorgue a esse representante tais poderes, esse não será capaz de propiciar a proteção necessária. Nesse caso, atuará apenas como um mandatário e, como tal, terá o direito de assumir obrigações em nome e em benefício dos mandantes, na administração dos interesses destes. No entanto, não terá legitimidade ordinária nem extraordinária para ajuizar ações em nome dos titulares de CCBs, que representa inclusive para execução de garantias.

A legitimidade é ordinária quando o titular do direito material em discussão é quem demanda esse direito em juízo. Já a legitimidade extraordinária, conforme define o processualista Nelson Nery Júnior (2007, p. 178), verifica-se nos casos em que "aquele que tem legitimidade para estar no processo como parte não é o que se afirma titular do direito material discutido em juízo".

De acordo com a maioria da doutrina, a legitimidade extraordinária apenas pode ser admitida se houver previsão legal. Não havendo tal previsão legal, como é o caso do agente de garantia, haveria uma espécie de substituição processual convencional, não autorizada por lei, que importaria a ilegitimidade do agente para demandar em nome próprio direito alheio. Esse é, inclusive, o entendimento do Superior Tribunal de Justiça. ${ }^{39}$

Seguindo esse entendimento, uma vez que o agente de garantia não é o titular do direito material, o agente não teria legitimidade ativa para demandar em nome próprio direito dos titulares das CCBs. É claro que há argumentos em sentido contrário. Pode-se buscar uma interpretação finalista e teleológica, argumentando que, com o consentimento

${ }^{39}$ No julgamento do Recurso Especial 286073 / MG em 2004, a Quarta Turma decidiu que "sendo o exequente mero mandatário do beneficiário dos títulos, não pode ele ingressar com a ação em nome próprio, postulando direito alheio", invocando o art. 6 do Código de Processo Civil. 
prévio de todos os titulares do direito material para que o agente tenha legitimidade para defender seus interesses, e, ainda, em vista da necessidade de se proteger de forma organizada tais interesses, não seria razoável o afastamento da legitimidade do agente para o estrito cumprimento de suas funções. Pode-se, ainda, pleitear que o magistrado, diante da ausência de normas específicas regulando a função do agente de garantia, aplique, por analogia, as normas relativas ao agente fiduciário, com base no artigo $4^{\underline{0}}$ da Lei de Introdução às normas do Direito Brasileiro (Decreto-Lei $\mathrm{n}^{\circ} 4.657$, de 4 de setembro de 1942), o qual determina que o juiz, quando a lei for omissa, decida o caso de acordo com a analogia, os costumes e os princípios gerais de direito.

Contudo, não obstante tais argumentos, é certo que, enquanto não houver uma previsão legal específica a respeito da legitimidade do agente de garantia, não haverá a segurança jurídica necessária para a atuação do agente de garantia na proteção dos interesses dos titulares de CCBs. É preciso que sejam criadas normas que assegurem tal proteção, semelhantes às existentes para o agente fiduciário. 


\section{CONCLUSÃO}

A CCB é, por natureza e por previsão legal, um título de crédito, que, na clássica definição de Cesare Vivante, consiste no documento necessário para o exercício do direito literal e autônomo nele mencionado.

Como título de crédito, a CCB é dotada de cartularidade, literalidade, autonomia e circularidade. Essas duas últimas características consistem, inclusive, nas grandes vantagens da CCB frente aos contratos de mútuo.

Não há qualquer discussão, seja na doutrina ou na jurisprudência, acerca da definição da CCB como título de crédito e de seus elementos característicos. Todas as controvérsias a respeito da natureza jurídica da CCB giram em torno de sua caracterização como valor mobiliário.

O fato de a CCB ser um título de crédito não impede que fosse também um valor mobiliário, desde que, evidentemente, preenchesse os requisitos legais para tanto. Embora sejam dois institutos distintos, há instrumentos que são ao mesmo tempo títulos de crédito e valores mobiliários. É o caso das debêntures, por exemplo. Entretanto, diante dos elementos característicos da $\mathrm{CCB}$ e do conceito de valor mobiliário adotado pelo direito brasileiro, expostos ao longo deste trabalho, é possível verificar que a CCB não se enquadra no conceito de valor mobiliário.

A definição de valor mobiliário encontra-se no artigo $2^{\circ}$ da Lei $n^{\circ} 6.385 / 76$. Uma vez que a CCB não está expressamente prevista no rol desse artigo, apenas poderia ser considerada um valor mobiliário caso se enquadrasse na hipótese de seu inciso IX, que abarca títulos e contratos de investimento coletivo. Para tanto, precisaria preencher os três requisitos presentes no referido dispositivo, quais sejam: ser passível de ser ofertada publicamente, gerar direito de participação, parceria ou remuneração e ter seus rendimentos advindos do esforço do empreendedor ou de terceiros.

A CCB nitidamente não preenche todos esses três requisitos. Muito embora a CCB seja um título de crédito passível de ser objeto de uma oferta pública - tanto de uma oferta 
pública tradicional quanto de uma oferta pública com esforços restritos - e que gera um direito de remuneração aos seus adquirentes, essa remuneração não advém dos esforços do empreendedor ou de terceiros. A remuneração sempre decorre da taxa de juros pactuada. Mesmo nos casos em que o empréstimo é feito para viabilizar um determinado empreendimento, a instituição financeira que concede o crédito não tem qualquer pretensão de participar desse empreendimento, assumindo tão somente o risco de crédito do emissor da CCB. Pode-se concluir, portanto, que a CCB é um instrumento típico do mercado de crédito e suas características não se coadunam com o conceito de investimento coletivo.

Logo, não se pode concordar, data vênia, com o entendimento da CVM de que a $\mathrm{CCB}$, quando ofertada publicamente, seria um valor mobiliário e essa oferta estaria, dessa forma, sujeita à supervisão da CVM. Diante do atual arcabouço jurídico brasileiro, não há fundamento legal para sujeitar as ofertas públicas de CCBs à autoridade da CVM. É preciso, portanto, que a proteção dos investidores de CCBs seja assegurada de outras formas, que não através da supervisão de sua oferta pública pela CVM.

Ademais, face as características e riscos inerentes à $\mathrm{CCB}$, mesmo que fosse possível considerá-la um valor mobiliário, a proteção que decorreria dessa caracterização não seria suficiente.

Inicialmente, porque tal proteção apenas seria assegurada nas ofertas públicas de CCB. Ainda que adotado o entendimento da CVM, a CCB somente seria considerada um valor mobiliário quando ofertada publicamente, em razão do previsto no artigo $2^{\circ}$, inciso IX, da Lei $n^{\circ} 6.385 / 76$, e esse título, no entanto, é negociado essencialmente de forma privada. Até a presente data, não há na CVM registros de oferta pública de CCBs. Deste modo, o reconhecimento, pela CVM, da CCB como valor mobiliário acaba por não ter um efeito prático relevante. Cabe aqui destacar também que não há no ordenamento jurídico brasileiro uma distinção conceitual entre oferta pública e privada de valor mobiliário, conforme analisado no Capítulo 5 da primeira parte deste trabalho. Dessa forma, não há critérios claros para se determinar se certa oferta de CCB seria pública e, portanto, no entendimento da CVM, estaria sujeita a registro perante essa autarquia, ou privada, o que gera insegurança entre os participantes do mercado. 
Além disso, o principal efeito da caracterização da CCB como valor mobiliário é submeter esse título ao regime do full disclosure, isto é, da plena disponibilização de informações. No entanto, uma ampla divulgação de informações não basta no caso da CCB. Guardadas as devidas proporções, a CCB lembra instrumentos financeiros que protagonizaram a recente crise financeira. Esse título é lastreado na concessão de crédito por instituições financeiras a pessoas físicas ou jurídicas, representando uma promessa de pagamento em dinheiro. Dessa forma, quem investe em uma CCB está, via de regra, assumindo o risco do beneficiário do crédito da CCB. Diga-se "via de regra", pois, em tese, as instituições financeiras podem assumir responsabilidade pelo adimplemento da obrigação representada pela $\mathrm{CCB}$, o que, no entanto, geralmente não ocorre. Para avaliar os riscos envolvidos em uma $\mathrm{CCB}$, é crucial que se faça uma análise minuciosa da solvabilidade do beneficiário do crédito representado por esse título. Porém, não se pode esperar que investidores, mesmo tendo acesso às informações apropriadas, tenham condições de verificar se a análise de risco de crédito foi realizada de forma correta.

É preciso regras específicas que assegurem que as próprias instituições concedentes do crédito façam uma avaliação de risco de crédito adequada no momento da concessão do crédito através da emissão de CCBs. Como visto no Capítulo 5 da segunda parte deste trabalho, o Ofício-Circular/CVM/SIN/N ${ }^{\circ}$ 02/2010 e as recentes mudanças feitas pela Anbima em seu Código de Regulação e Melhores Práticas para Fundos de Investimento, ambos a respeito de regras e procedimentos a serem adotados pelos administradores e gestores de fundos de investimento para a aquisição de CCBs, representam um importante passo para uma proteção mais eficaz dos investidores. Porém, é preciso mais do que isso.

Sendo permitido que as instituições financeiras passem adiante, logo após a concessão do crédito, todo o risco atrelado a tal crédito, as instituições deixam de ter incentivos para gastar recursos em análises de risco minuciosas, as quais são imprescindíveis para a proteção dos investidores. Conforme exposto no Capítulo 5 da segunda parte deste trabalho, se os riscos não forem devidamente apurados pelas instituições financeiras, no momento da concessão do crédito, se, nesse momento, não forem reunidas pela instituição concedente do crédito as informações necessárias para tal apuração, mesmo investidores com capacidade de realizarem uma análise de risco, como gestores de fundos, por exemplo, dificilmente conseguirão fazer uma análise apropriada e ficarão expostos a riscos desconhecidos. 
Como também visto no Capítulo 5, a necessidade de uma análise apropriada de risco de crédito ficou ainda mais evidente após a crise financeira de 2008. A crise, da qual o mundo ainda não se recuperou plenamente, mostrou quão devastador pode ser o efeito da falta de uma análise adequada de risco.

Nos Estados Unidos, esse problema já vem sendo tratado. Já existem regras que abordam exatamente a questão da transferência do risco de crédito, as quais começaram a ser editadas após essa questão ser apontada como uma das causas da crise de 2008. Tais regras exigem a retenção de, no mínimo, 5\% do risco de crédito pelos originadores ou pelas securitizadoras. No Brasil, por sua vez, ainda $100 \%$ dos créditos podem ser passados adiante, carregando riscos indevidamente apurados.

Também contribuiria para a proteção dos investidores de CCBs regras que regulamentassem a atuação do agente de garantia nas distribuições desse título, sejam públicas ou privadas. É comum nas emissões de CCBs que haja um "agente de garantia" para monitorar o cumprimento das obrigações representadas pelas cédulas, gerenciar as garantias e, se necessário, executá-las. Esse agente é de grande importância para os investidores.

Os titulares de $\mathrm{CCBs}$ emitidas pela mesma pessoa física ou jurídica representam uma comunhão de interesses e, na grande maioria das vezes, há uma impossibilidade prática de eles próprios defenderem seus interesses. Daí a necessidade de um agente de garantia que seja um profissional ou uma instituição especializada capaz de defender os interesses de tais investidores. Todavia, não existe, atualmente, uma previsão legal que outorgue a tal representante legitimidade para agir em nome dos titulares de CCBs.

Ainda que haja argumentos para sustentar que o agente de garantia teria legitimidade para representar os titulares de CCBs que o nomearam, inclusive para fins da execução de garantias, enquanto não houver uma previsão legal específica a respeito da legitimidade do agente de garantia, não haverá a segurança jurídica necessária para a atuação desse agente na proteção dos interesses dos titulares de CCBs. É preciso que o representante dos titulares de CCBs possua poderes legais para assegurar uma proteção eficaz a esses investidores, semelhantes aos poderes dos agentes fiduciários de debêntures. 
Sem um novo arcabouço jurídico, os investidores de CCBs continuarão sujeitos a riscos que, na grande maioria das vezes, desconhecem ou não têm condições de avaliar. Antes de investirem diretamente em CCBs ou em fundos de investimento cujas carteiras são compostas por CCBs, os quais existem em grande número no mercado, os investidores devem, sem dúvida, atentar para tais riscos e ponderar se cabe assumi-los. Porém, sem uma proteção adequada, os investidores muitas vezes acabam assumindo riscos sem terem conhecimento e além do que sua condição financeira permitiria. Ademais, a experiência mostra que essa proteção transcende o interesse direto e imediato dos investidores, compondo um instrumento de resguardo à economia nacional. 


\section{REFERÊNCIAS BIBLIOGRÁFICAS}

ABRÃO, Carlos Henrique. Cédula de crédito bancário. São Paulo: Juarez de Oliveira, $2005,163 p$.

ALMEIDA, Amador Paes de. Teoria e prática dos títulos de crédito. 27. ed. São Paulo: Saraiva, 2008, 606p.

ALMEIDA, Samy Sanches de. Crise dos Derivativos: Reforma Dodd-Frank e o Clearing Centralizado. Revista de Direito Mercantil, Industrial, Econômico e Financeiro, São Paulo, Revista dos Tribunais, n. 157, p. 167-185, jan.-mar. 2011.

ANDREZO, Andréia F.; LIMA, Iran S. Mercado Financeiro: aspectos históricos $e$ conceituais. São Paulo: Pioneira, 1999, 326p.

ASCARELLI, Tullio. Problemas das Sociedades Anônimas e Direito Comparado. Campinas: Bookseller, 1999.

; GIANCOBBINI, Benedicto. Teoria geral dos títulos de crédito. São

Paulo: RED Livros, 1999, 445p.

ASQUINI, Alberto. Titoli di Credito. Milano: Cedam, 1966.

BARBOSA, Fernando Cabeças; CALHEIROS, Paulo Duric. A flagrante inconstitucionalidade da MP n. 1925/99 que alterou a legislação sobre a cédula de crédito bancário, RIJ - (Civil, Processual, Penal e Comercial), n. 7, abr. 2000.

BARRETO FILHO, Oscar. Sociedades de crédito, financiamento e investimento. Revista do Instituto de Pesquisas e Estudos, 1966. p. 173 e ss.

DE BARROS, Benedito Ferri. O mercado de capitais dos Estados Unidos. Investment Bankers Association of América. 2. ed. São Paulo: Empresa Gráfica da Revista dos Tribunais, 1970. 
BOBBIO, Norberto. Estado, governo e sociedade. Para uma teoria geral da política. 3. ed. São Paulo: Editora Paz e Terra, 1987.

BOCATER, Maria Isabel do Prado; LOIOLA, Leandro. Aspectos Atuais da Regulamentação de Distribuições Públicas de Títulos e Valores Mobiliários. Revista de Direito Bancário e do Mercado de Capitais. São Paulo: Revista dos Tribunais, ano 14, n. 53, p. 109-124, jul.-set. 2011.

BRANCO, Gerson Luiz Carlos. Cédula de crédito bancário: estrutura e funcionalidade. Revista de Direito do Consumidor. São Paulo: Revista dos Tribunais, v. 17, n. 65, p. 114143, jan.-mar. 2008.

BRUSACO, Margaret. Legal Status of Securities in English Law. Le Régime Juridique dês Titres des Sociétés en Europe et aux États Unis, Bruxelas, p. 163-164, 1970.

BRUSCATO, Wilges. Proteção Judicial no Mercado de Valores Mobiliários. Revista de Direito Mercantil, Industrial, Econômico e Financeiro. São Paulo: Revista dos Tribunais, n. 138 , p. 35-52, abr.-jun. 2005.

BULGARELLI, Waldirio. Os valores mobiliários como títulos de crédito. Revista de Direito Mercantil, Industrial, Econômico e Financeiro. São Paulo: Revista dos Tribunais, n. 37, p. 94-112, jan.-mar. 1980.

Títulos de crédito. 16. ed. São Paulo: Atlas, 2000, 602p.

CAMILO JUNIOR, Ruy Pereira. A reforma do sistema financeiro norte-americano. Revista de Direito Bancário e do Mercado de Capitais, São Paulo: Revista dos Tribunais, v. 14, n. 54, p. 59-98, out.-dez. 2011.

CAMINHA, Unie. A securitização: função econômica e regime jurídico. Dissertação para obtenção de título de Doutora. Faculdade de Direito da Universidade de São Paulo, 2004. 
CARVAlHOSA, Modesto. Comentários à Lei de Sociedades Anônimas. v. I. Saraiva: São Paulo, 2009. . Comentários à Lei de Sociedades Anônimas. v. II. Saraiva: São

Paulo, 2009. Comentários à Lei de Sociedades Anônimas. v. IV. Saraiva: São Paulo, 2009.

; EIZIRIK, Nelson. Estudos sobre direito empresarial. São Paulo: Saraiva, 2010, 578p.

CHOI, Stephen. Regulating investors, not issuers: A Market Based Proposal. UC Berkeley Law and Economics Working paper 2000. Disponível em: <http://escholarship.org/uc/item/36h9c7gq>. Acesso em: 18 mar. 2011.

COFFEE JR., John C.; SELIGMAN, Joel; SALE, Hillary A. Securities Regulation. Brooklyn: Foundation Press, 2007.

COMPARATO, Fabio Konder. Novos Ensaios e pareceres de direito empresarial. Rio de Janeiro: Forense, 1981.

COSTA, Philomeno J. Anotações às companhias. v. I. São Paulo: Revista dos Tribunais, 1980.

COVAS, Silvanio. O título de crédito eletrônico e a cédula de crédito bancário. In: FONTES, Marco Rolim Fernando e WAISBERG, Ivo (Org.). Contratos Bancários. São Paulo: Quartier Latin, 2006, p. 459-479.

CUNHA, Antônio Geraldo. Dicionário etimológico da língua portuguesa. Rio de Janeiro: Lixikon Editora Digital, 2007. 
DIAS, Luciana Pires. Regulação e Autorregulação no Mercado de Valores Mobiliários. Dissertação para obtenção de título de mestre. Faculdade de Direito da Universidade de São Paulo, 2005.

EIZIRIK, Nelson. O papel do Estado na regulação do Mercado de Capitais. Rio de Janeiro: IBMEC, 1977.

Questões de direito societário e mercado de capitais. Rio de Janeiro: Forense, 1987.

Caracterização jurídica da emissão pública de valores mobiliários. Revista de Direito Mercantil, Industrial, Econômico e Financeiro, São Paulo: Revista dos Tribunais, n. 83, p. 55-61, jul.-set. 1991.

. Emissão pública de valores mobiliários. Aspectos modernos do direito societário. Rio de Janeiro: Renovar, 1992.

Os valores mobiliários na nova lei das S/A. Revista de Direito Mercantil, Industrial, Econômico e Financeiro, São Paulo: Revista dos Tribunais, n. 124, p.72-79, out.-dez. 2001.

Sistema de transferência de propriedade das cédulas de crédito bancário (CCB's) por meio de negócios realizados na CETIP. Rio de Janeiro, 2006. Mercado de Capitais. Regime Jurídico. São Paulo: Renovar, 2008.

A polêmica sobre a cédula de crédito bancário. Artigo publicado no Jornal Valor Econômico em 25.2.2008. Disponível em: $<$ http://www.sasp.org.br/index.php/boletim-juridico/144-a-polemica-sobre-a-cedula-decredito-bancario.html>. Acesso em: 18 mar. 2011.

FERREIRA, José Coêlho; BARBOSA, Theresa Karina de F. G. Cédula de crédito bancário. Considerações acerca da Medida Provisória 1.925. Revista de Direito Bancário e 
do Mercado de Capitais e da Arbitragem, São Paulo: Revista dos Tribunais, ano 3, n. 8, p. 96-106, abr.-jun. 2000.

FERREIRA, Waldemar Martins. Tratado das Debêntures. Rio de Janeiro: Freitas Bastos, 1944.

FERRI, Giuseppe. Titoli Di Credito. Torino: Unione Tipográfico-Editrice Torinese, 1965.

FRONTINI, Paulo Salvador. Cédulas de crédito bancário. Revista de Direito Mercantil, Industrial, Econômico e Financeiro. São Paulo: Revista dos Tribunais, n.119, p. 52-67, jul.-set. 2000.

- Títulos de crédito e títulos circulatórios: que futuro a informática lhes reserva? Revista dos Tribunais, São Paulo: Revista dos Tribunais, v. 85, n. 730, p. 50-67, ago. 1996.

GAAL, Ariadna Bohomoletz. A caracterização de emissão pública e privada de valores mobiliários no Direito Americano. Revista de Direito Mercantil, Industrial, Econômico e Financeiro, São Paulo: Revista dos Tribunais, n. 63, p. 48-70, jul.-set. 1986.

GALBRAITH, John Kenneth. Moeda: De Onde Veio, Para Onde Foi. São Paulo: Pioneira, 1997, 312p.

GOUTAY, Philippe. O conceito de valor mobiliário. Tradução Rogério Acquarone. Revista de Direito Bancário, do Mercado de Capitais e da Arbitragem, São Paulo: Revista dos Tribunais, n. 8, p. 229-240, abr.-jun. 2000.

HENRIQUES, Marcus de Freitas. CCBs: ser ou não ser valores mobiliários. Disponível em: $\quad<$ http://www.insightnet.com.br/revistacustobrasilu/14/pdfs/Artigo\%2006\%20$\% 20$ Custo\%20do\%20capital.pdf>. Acesso em: 27 jun. 2012.

KEMPA, Michal. Liquidity Crisis in the Interbank Market. Disponível em: <http://ssrn.com/abstract=1138705>. Acesso em: 22 mar. 2011. 
LAMY FILHO, Alfredo; PEDREIRA, José Luiz Bulhões. A Lei das S.A. Rio de Janeiro: Renovar, 1992.

LEÃES, Luiz Gastão Paes de Barros. O conceito de 'security` no direito norte-americano e o conceito análogo no Direito Brasileiro. Revista de Direito Mercantil, Industrial, Econômico e Financeiro, São Paulo: Revista dos Tribunais, n. 14, p. 41-60, 1974.

- Negociação de Cédula de Crédito Bancário na CETIP. Revista de Direito Bancário e do Mercado de Capitais, São Paulo: Revista dos Tribunais, n. 50, p. 215-238, out.-dez. 2010.

LIMA, Osmar Brina Corrêa. O conceito de valor mobiliário nos Direitos Brasileiros e Norte-Americano. Disponível em: <http://www.cjf.gov.br/revista/seriecadernos/VOL166.htm>. Acesso em: 18 mar. 2011.

LOPES, Alexandro Broedel. Operações com derivativos: uma introdução multidisciplinar e algumas lições da crise no Brasil. Revista de Direito Mercantil, Industrial, Econômico e Financeiro, São Paulo: Revista dos Tribunais, n. 148, p. 17-26, out.-dez. 2007.

LOSS, Louis. O papel do governo na proteção dos investidores. Revista de Direito Mercantil, Industrial, Econômico e Financeiro, São Paulo: Revista dos Tribunais, n. 58, p. 71-87, 1985.

LUCCA, Newton de. A Cambial-Extrato. São Paulo: Revista dos Tribunais, 1985. A Ação da Sociedade Anônima como objeto de Negociação no Mercado de Valores Mobiliários. Disponível em: <http://www.cjf.jus.br/revista/seriecadernos/VOL15-6.htm>. Acesso em: 28 jun. 2012.

LUCENA, José Waldecy. Das sociedades Anônimas - Comentários à Lei. v. I. Rio de Janeiro: Renovar, 2009.

MAMEDE, Gladston. Direito empresarial brasileiro: títulos de crédito. v. 3. 5. ed. São Paulo: Atlas, 2009, 488p. 
MARTINS, Fran. Comentários à Lei de Sociedades Anônimas. v. I. Rio de Janeiro: Forense, 1977.

Títulos de crédito. 14. ed. Rio de Janeiro: Forense, 2008, 533p.

MATTOS FILHO, Ary Oswaldo. O conceito de valor mobiliário. Revista de Direito Mercantil, Industrial, Econômico e Financeiro, São Paulo: Revista dos Tribunais, n. 59, p. 30-55, 1985.

CCB é valor mobiliário? Revista Capital Aberto, ano 5, n. 56, abril 2008. Disponível em: <http://www.capitalaberto. com.br/ler_artigo.php?pag=2\&i=1879\&sec=21>. Acesso em: 21 mar. 2011.

MICHAEL P. MALLOY. The Definition of Security: Marine Bank v. Weaver, 1983. Disponível em: <http://lawdigitalcommons.bc.edu/bclr/vol24/iss4/5>. Acesso em: 17 nov. 2011.

MIRANDA, Pontes de. Tratado de Direito Cambiário. v. I. Campinas: Bookseller, 2000.

NERY JÚNIOR, Nelson; NERY, Rosa Maria de Andrade. Código de Processo Civil e legislação extravagante. 10. ed. São Paulo: Editora Revista dos Tribunais, 2007.

OHL, Daniel. Droit des Sociétés Cotée. Paris: Litec, 2003.

PAULIN, Luiz Alfredo. Transferência de cédula de crédito bancário sem coobrigação. Responsabilidade de instituição financeira por inadequada análise de crédito e desrespeito ao princípio da boa fé. Revista do Direito Bancário e do Mercado de Capitais, São Paulo: Revista dos Tribunais, v. 11, n. 39, p. 32-55, jan.-mar. 2008.

PENTEADO, Mauro Rodrigues (Coord.). Títulos de crédito: teoria geral e títulos atípicos em face do Novo Código Civil (análise dos artigos 887 a 903): títulos de crédito eletrônicos. São Paulo: Walmar, 2004, 448p. 
PEREIRA FILHO, Valdir Carlos. Cédula de crédito bancário. In: FONTES, Marco Rolim Fernando; WAISBERG, Ivo (Org.). Contratos Bancários. São Paulo: Quartier Latin, 2006. p. 279-306.

Proposed SEC Rule 146: The Quest for Objectivity, 41 Fordham L. Rev. 887 (1973), Disponível em: <http://ir.lawnet.fordham.edu/flr/vol41/iss4/4>. Acesso em: 30 maio 2011.

QUEIROZ, José Eduardo Carneiro. Valor mobiliário, oferta pública e oferta privada: conceitos para o desenvolvimento do mercado de capitais. Revista de Direito Bancário e do Mercado de Capitais, São Paulo: Revista dos Tribunais, ano II, v. 41, p. 121-126, jun.set. 2008 .

ROSEN, R. C.; WALKER, G. R.; ANDERSON, K. International Securities Regulation. Nova York: Oceana Publications, 2011.

RUDGE, Luiz Fernando; CAVALCANTE, Francisco. Mercado de capitais. Belo Horizonte: Comissão Nacional de Bolsas de Valores - CNBV, 1996.

SABRY, Faten. What do the new risk retention requirements of the Dodd-Frank Act mean for securitization? Disponível em: <http://www.nera.com/nerafiles/PUB_Economic_Analysis_Sabry_1210.pdf>. Acesso em: 17 nov. 2011.

SALLES, Marcos Paulo de Almeida. Os valores mobiliários na Lei das S.A. Revista de Direito Mercantil, Industrial, Econômico e Financeiro, São Paulo: Revista dos Tribunais, n. 107, p. 123-128, jul.-set. 1991.

SANTOS, Theophilo de Azevedo. Notas sobre a cédula de crédito bancário. Revista de Direito Bancário e do Mercado de Capitais e da Arbitragem, São Paulo: Revista dos Tribunais, ano 3, n. 8, p. 86-95, abr.-jun. 2000.

SCHWARTZ, Stanley Jr. Rule 146: The Private Offering Exemption - Historical Perspective and Analysis, 1974. Disponível em: <http://heinonline.org/HOL/LandingPage? collection=journals \&handle=hein.journals/ohslj35\&div=48\&id=\&page $=>$. Acesso em: 30 maio 2011. 
THEODORO JUNIOR, Humberto. A cédula de crédito bancário. Revista de Direito Bancário, do Mercado de Capitais e da Arbitragem, São Paulo: Revista dos Tribunais, ano 6, n. 22, p. 13-52, out.-dez. 2003.

A cédula de crédito bancário. Revista Forense, Rio de Janeiro: Forense, v. 101, n. 380 p. 119-148, jul.-ago. 2005.

TOLEDO, Paulo Fernando Campos Salles de. Valores mobiliários - inteligência do art. $2^{\circ}$ $n^{\circ}$ III, da lei 6.385, de 1976. Revista Justiça, São Paulo: Ministério Público do Estado de São Paulo, v. 122, p. 176-184, 1983.

Ainda a abstração. Revista de Direito Mercantil Industrial, Econômico e Financeiro, São Paulo: Revista dos Tribunais, n. 80, p. 133-137, 1990.

VALVERDE, Trajano de Miranda. Sociedades por Ações. v. II. Rio de Janeiro: Forense, n. $522,1953$.

VERÇOSA, Haroldo Malheiros Duclerc. A CVM e os contratos de investimento coletivo ("Boi gordo" e outros). Revista de Direito Mercantil, Industrial, Econômico e Financeiro, São Paulo: Revista dos Tribunais, n. 108, p. 91/100, out.-dez. 1997.

Notas sobre o regime jurídico das ofertas ao público de produtos, serviços e valores mobiliários no direito brasileiro. Uma questão de complementação da proteção de consumidores e de investidores. Revista de Direito Mercantil, Industrial, Econômico e Financeiro, São Paulo: Revista dos Tribunais, n. 105, p. 74-83, jan.-mar. 1997.

A cédula de crédito bancário (Medida Provisória 1.925, de 14.10.1999). Revista de Direito Mercantil, Industrial, Econômico e Financeiro, São Paulo: Revista dos Tribunais, n. 116, p. 129-135, out.-dez. 1999. 
A Cédula de Crédito Bancário (CCBs) como

Valores Mobiliários. Revista de Direito Mercantil, Industrial, Econômico e Financeiro, São Paulo: Revista dos Tribunais, n. 144, p.120-127, out.-dez. 2006.

Considerações sobre o sistema financeiro. Crises.

Regulação e re-regulação. Revista de Direito Mercantil, Industrial, Econômico e Financeiro, São Paulo: Revista dos Tribunais, n. 149-150, p. 9-31, jan.-dez. 2008.

VILLELA FILHO, Gustavo Alberto. A exigência de registro prévio de CCBs na CVM. Disponível em: <http://www.debenture.com.br/informacoesaomercado/noticias.asp?mostra =5157\&pagina=-37>. Acesso em: 18 abr. 2011.

O investidor deve ter tanta apreensão com CCBs?

Disponível em: <http://www.vk.adv.br/mod_artigos_10.asp?nav=4>. Acesso em: 18 abr. 2011.

WALD, Arnoldo. Dos conceitos de emissão e de oferta pública na legislação do mercado de capitais. Estudos e Pareceres de Direito Comercial, 2. Série, São Paulo: Revista dos Tribunais, p. 146-161, 1979.

O mercado futuro de índices e os valores mobiliários. Revista de Direito Mercantil, Industrial, Econômico e Financeiro, São Paulo: Revista dos Tribunais, v. 57, p. 5-18, jan.-mar. 1985.

YAZBEK, Otavio. O risco de crédito e os novos instrumentos financeiros: uma análise funcional. In: FONTES, Marco Rolim Fernando; WAISBERG, Ivo (Org.). Contratos Bancários. São Paulo: Quartier Latin, 2006, p. 459-479.

Regulação do Mercado Financeiro e de Capitais. 2. ed. Rio de Janeiro:

Elsevier, 2009.

ZACLIS, Lionel. Proteção coletiva dos investidores no mercado de capitais. São Paulo: Revista dos Tribunais, 2007. 